\title{
RIVER-RAD: A COMPUTER CODE FOR SIMULATING THE TRANSPORT OF RADIONUCLIDES IN RIVERS
}

\author{
D. M. Hetrick* \\ L. M. McDowell-Boyer** \\ A. L. Sjoreen* \\ D. J. Thorne** \\ M. R. Patterson*
}

*Computing and Telecommunications Division

**Health and Safety Research Division

Date Published - November 1992

\footnotetext{
OAK RIDGE NATIONAL LABORATORY

Oak Ridge, Tennessee 37831

managed by

MARTIN MARIETTA ENERGY SYSTEMS, INC. for the

U.S. DEPARTMENT OF ENERGY

under contract DE-AC05-84OR21400
} 


\section{CONTENTS}

ABSTRACT

1. INTRODUCTION 5

2. RIVER-RAD - MODEL DESCRIPTION 6

2.1 RADIONUCLIDE TRANSPORT IN A RIVER REACH . . . . . . . 7

2.2 THE DETERMINATION OF DISSOLVED AND SORBED RADIONUCLIDES $\ldots \ldots \ldots \ldots \ldots \ldots \ldots \ldots \ldots \ldots, 8$

3. STRUCTURE OF THE RIVER-RAD PROGRAM 10

3.1 SUBROUTINE STRUCTURE $\ldots \ldots \ldots \ldots \ldots \ldots \ldots \ldots$

3.2 SUBPROGRAM DESCRIPTIONS . . . . . . . . . . . . . . . . 12

3.2.1 The MAIN Program $\ldots \ldots \ldots \ldots \ldots \ldots \ldots \ldots$

3.2.2 Subroutine ALPHA . . . . . . . . . . . . . . . 12

3.2.3 Subroutine DECSRC . . . . . . . . . . . . . . 12

3.2.4 Subroutine EXEC ... . . . . . . . . . . . . . . 12

3.2.5 Subroutine FUNLAU $\ldots \ldots \ldots \ldots \ldots \ldots \ldots \ldots$

3.2.6 Subroutine MATACT $\ldots \ldots \ldots \ldots \ldots \ldots \ldots \ldots \ldots$

3.2.7 Subroutine OUTPUT . . . . . . . . . . . . . . 13

3.2.8 Subroutine READIN . . . . . . . . . . . . . . 13

3.2.9 Subroutine SEDCON $\ldots \ldots \ldots \ldots \ldots \ldots \ldots \ldots \ldots$

3.2.10 Function SPLEVA . . . . . . . . . . . . . . . . . 14

3.2.11 Subroutine VFALL . . . . . . . . . . . . . . . . 14

3.2.11 Subroutine WATER $\ldots \ldots \ldots \ldots \ldots \ldots \ldots \ldots$

4. RIVER-RAD OPERATION 14

4.1 MODE OF OPERATION .................. 14

4.2 INPUT DATA ........................ 15

5. DESCRIPTION OF CODE OUTPUT

5.1 RESULTS WRITTEN TO OUTPUT.USR . . . . . . . . . . 20

5.2 RESULTS WRITTEN TO OUTPUT.RIV . . . . . . . . . . 21

6. DISCUSSION 21

REFERENCES 23

APPENDIX A

LISTING OF RIVER-RAD . . . . . . . . . . . . . . . . . . 24 
APPENDIX B

IMPORTANT PARAMETERS AND THEIR DEFINITIONS . . . . 42

APPENDIX C

EXAMPLES OF INPUT FILES FOR RIVER-RAD $\ldots \ldots \ldots \ldots \ldots 53$

APPENDIX D

RESULTS FROM THE RIVER-RAD MODEL $\ldots \ldots \ldots \ldots \ldots .59$

APPENDIX E

MODEL RESULTS COMPARED WITH ANALYTICAL

CALCULATIONS ..................... 71 


\title{
RIVER-RAD: A COMPUTER CODE FOR SIMULATING THE TRANSPORT OF RADIONUCLIDES IN RIVERS
}

\author{
D. M. Hetrick, L. M. McDowell-Boyer, A. L. Sjoreen \\ D. J. Thorne, and M. R. Patterson
}

\begin{abstract}
A screening-level model, RIVER-RAD, has been developed to assess the potential fate of radionuclides released to rivers. The model is simplified in nature and is intended to provide guidance in determining the potential importance of the surface water pathway, relevant transport mechanisms, and key radionuclides in estimating radiological dose to man. The purpose of this report is to provide a description of the model and a user's manual for the FORTRAN computer code.
\end{abstract}

\section{INTRODUCTION}

A screening-level model for simulating the transport of radionuclides in rivers has been developed to assist in determining the importance of this pathway in estimating radiological dose to man. The purpose of the present report is to provide a description of the model RIVER-RAD - a computer program that combines the river portion of the screening-level multimedia model TOX-SCREEN (McDowell-Boyer and Hetrick, 1982; Hetrick and McDowell-Boyer, 1984) and the radioactive decay and daughter buildup algorithms from the MLSOIL model (Sjoreen et al., 1984). In addition, a sediment bed compartment has been included in the model. RIVER-RAD was developed to provide guidance in determining the importance of the surface water pathway, relevant transport mechanisms, and key radionuclides through screening-level calculations.

The RIVER-RAD computer code is written in FORTRAN. The program reads two data files provided by the user - WATER.IN and RADIO.IN - and outputs results in two files - OUTPUT.USR and OUTPUT.RIV (these file names are in OPEN statements in the code and thus can be changed easily). The code is not interactive in that it does not prompt the user for information during execution, but reads all data from the two input files.

A complete description of the model and the assumptions used are given in Sect. 2 of this document. The structure of the program and subprogram descriptions are given in Sect. 3. Section 4 describes how to use RIVER-RAD and gives a complete description of the input data. A description of the code output is given in Sect. 5. A discussion is included in Sect. 6. A listing of the program is given in Appendix A, and Appendix B provides a table of important parameters that are used frequently in the program and their definitions, to allow the user quick access to this information. Example input data are given in Appendix $C$, and the corresponding output from RIVER-RAD is provided in Appendix D. Appendix E compares model results to analytical calculations. 


\section{RIVER-RAD - MODEL DESCRIPTION}

Radionuclides are transported through a river system in RIVER-RAD via a compartmental linear transfer model (see Fig. 1). The river is divided into reaches (compartments) of equal size, each with a sediment compartment below it. The movement of radionuclides is represented by a series of transfers between the reaches, and between the water and sediment compartments of each reach. Within each reach (for both the water and sediment compartments), the radionuclides are assumed to be uniformly mixed. Upward volatilization is allowed from the water compartment, and the transfer of radionuclides between the reaches is determined by the flow rate of the river. Settling and resuspension velocities determine the transfer of adsorbed radionuclides between the water and sediment compartments. Radioactive decay and decay-product buildup are incorporated into all transport calculations for all radionuclide chains specified by the user. Each nuclide may have unique input and removal rates. Volatilization and radiological decay are considered as linear rate constants in the model.

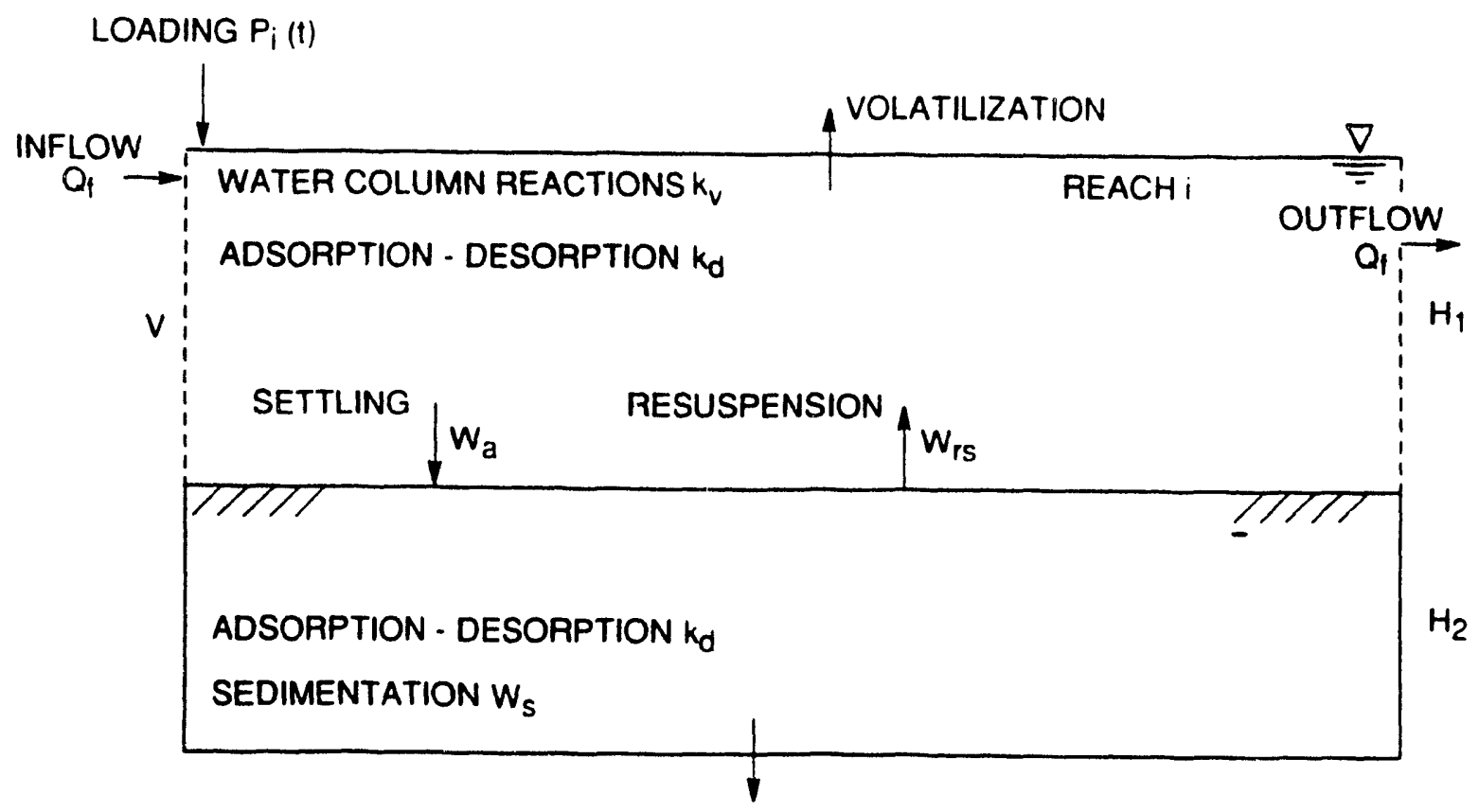

Fig. 1. River system in RIVER-RAD. See page 7 for parameter definitions. 


\section{RADIONUCLIDE TRANSPORT IN A RIVER REACH}

The rate of change of activity of radionuclide $i(i=1$ for parent and $i=2, \mathrm{n}$ for daughters) in the water column of a river reach is given by

$$
\begin{aligned}
& \frac{d A_{l}}{d t}=P_{i}(t)-\lambda_{i} A_{l}-k_{r} A_{l}+\lambda \sum_{j=1}^{l-1} b_{i} A_{j}-\frac{w_{a} \alpha_{2 w} A_{l}}{H_{1}}+\frac{w_{r g} \alpha_{2} B_{l}}{H_{2}}, \\
& \frac{d B_{l}}{d t}=-\lambda_{l} B_{i}+\lambda \sum_{j=1}^{l-1} b_{v} B_{j}+\frac{w_{e} \alpha_{2 \alpha} A_{l}}{H_{1}}-\frac{w_{r s} \alpha_{2 s} B_{l}}{H_{2}}-\frac{w_{g} \alpha_{2 s} B_{l}}{H_{2}},
\end{aligned}
$$

where

$A_{i} \quad=\quad$ activity of nuclide $i$ in the water column (Ci),

$A_{j}=$ activity of $j(j<i)$, a parent of daughter $i$, in the water column (Ci),

$b_{i j}=$ radioactive branching ratio from nuclide $j$ to nuclide $i(j<i)$,

$B_{i}=$ activity of nuclide $i$ in the sediment column (Ci),

$B_{j} \quad=\quad$ activity of $j(j<i)$, a parent of daughter $i$, in the sediment column (Ci),

$H_{1}=$ depth of the water column (m),

$H_{2}=$ depth of the sediment layer $(\mathrm{m})$,

$k_{t}=Q_{f} / V+\alpha_{1 w} k_{v}\left(\mathrm{~s}^{-1}\right)$,

$k_{v}=$ first-order volatilization rate constant $\left(\mathrm{s}^{-1}\right)$,

$\mathbf{P}_{\mathrm{i}}(t)=$ the rate at which radionuclide $i$ enters the reach $(\mathrm{Ci} / \mathrm{s})$,

$Q_{f}=$ river flow rate $\left(\mathrm{m}^{3} / \mathrm{s}\right)$,

$V=$ volume of reach $\left(\mathrm{m}^{3}\right)$,

$w_{a}=$ settling velocity of adsorbing particles from the water column to the sediment layer $(\mathrm{m} / \mathrm{s})$,

$w_{r s}=$ resuspension velocity of the adsorbing particles from the sediment layer to the water column $(\mathrm{m} / \mathrm{s})$,

$w_{s}=$ sedimentation velocity or rate of burial $(\mathrm{m} / \mathrm{s})$.

$\alpha_{1 w}=$ fraction of radionuclide in dissolved phase in the water column (see Sect. 2.2),

$\alpha_{2 s}=$ fraction of radionuclide in particulate phase in the sediment layer (see Sect. 2.2),

$\alpha_{2 v}=$ fraction of radionuclide in particulate phase in the water column (see Sect. 2.2),

$\lambda_{i}=$ first-order radiological decay constant, nuclide $i\left(\mathrm{~s}^{-1}\right)$.

The activity of all radionuclides in a reach at time $t$ are obtained by solving the set of simultaneous equations represented by Eqs. (1) and (2). In RIVER-RAD the initial activities of the radionuclides are assumed to be zero. In the first reach of the river, a source, $P_{i}(t)$, can be input for the parent radionuclides only. However, more than one radionuclide chain can be handled in one simulation. Thus, a parent for one chain can be a daughter in another chain that is input to the code. Subsequent river reaches receive input sources for both parent and daughter radionuclides from the preceding reaches. 
The system of equations given by Eqs. (1) and (2) can be expressed as a vector-matrix differential equation. The matrix operator method of Lee (1976) is used for solving the system in RIVER-RAD. This method has been described in detail for MLSOIL, a model of radionuclide transport through soil (Sjoreen et al., 1984), and thus will not be discussed here.

\section{THE DETERMINATION OF DISSOLVED AND SORBED RADIONUCLIDES}

Some elements in the lanthanide and actinide series have high distribution coefficients and thus a high affinity for adsorption to sediments. Radionuclide interactions with sediment are modeled by use of the distribution coefficient, $K_{d}$, defined as

$$
K_{d}=\frac{\text { atoms of radiomalide adsabed } / \mathrm{g} \text { soil }}{\text { atoms of radiomalide dissolved / } \mathrm{mL} \text { water }} .
$$

It follows that the fractions of the radionuclide activity in the dissolved $\left(\alpha_{1 w}\right)$ and sorbed $\left(\alpha_{2 v}\right)$ forms of the water column are

$$
\alpha_{1 w}=\frac{1}{1+K_{d} * S}
$$

and

$$
\alpha_{2 w}=\frac{K_{d} * S}{1+K_{d} * S}
$$

and in the dissolved $\left(\alpha_{1 s}\right)$ and sorbed $\left(\alpha_{2 s}\right)$ forms of the sediment layer, are

$$
\alpha_{1 s}=\frac{1}{1+K_{d} * S_{b}}
$$

and

$$
\alpha_{2 s}=\frac{K_{d} * S_{b}}{1+K_{d} * S_{b}}
$$

where

$S \quad=$ suspended sediment concentration in the river $(\mathrm{g} / \mathrm{mL})$,

$S_{b} \quad=$ sediment concentration in the sediment bed $(\mathrm{g} / \mathrm{mL})$.

The RIVER-RAD model gives the user the option of either entering or calculating $S$. The sediment concentration $S(\mathrm{~g} / \mathrm{mL})$ can be calculated as follows: 


$$
S=\frac{0.001 * \bar{c}}{\frac{\bar{c}}{\gamma_{s}}+\frac{100-\bar{c}}{\gamma}}
$$

where

$\gamma_{s} \quad=$ the sediment density $\left(\mathrm{kg} / \mathrm{m}^{3}\right)$,

$\gamma \quad=$ water density $\left(1000 \mathrm{~kg} / \mathrm{m}^{3}\right)$,

and the following formula from Laursen (1958) can be used to compute $\bar{c}$ :

$$
\bar{c}=\sum_{l} p_{l}\left(\frac{d_{l}}{H_{1}}\right)^{\frac{7}{6}}\left(\frac{\tau_{0}^{\prime}}{\tau_{c}}-1\right) f\left(\frac{\sqrt{H_{1} s g}}{w_{c}}\right),
$$

where

$\bar{c}=$ mean sediment concentration (wt \%),

$d_{i} \quad=$ median sediment particle diameter (m) of size class $i$,

$f() \quad=$ Laursen's function,

$g=$ acceleration of gravity $\left(\mathrm{m} / \mathrm{s}^{2}\right)$,

$H_{1} \quad=$ water depth (m),

$i \quad=$ sediment size class,

$p_{i} \quad=$ fraction of bed material of diameter $d_{i}$,

$s \quad=$ slope of the river $(\mathrm{m} / \mathrm{m})$,

$w_{a} \quad=$ fall velocity for $d_{i}(\mathrm{~m} / \mathrm{s})$,

$\tau_{0}^{\prime}=$ boundary shear associated with sediment particles $\left(\mathrm{kg} / \mathrm{m}^{2}\right)$,

$\tau_{c} \quad=$ critical tractive force $\left(\mathrm{kg} / \mathrm{m}^{2}\right)$.

The boundary shear $\left(\tau_{0}{ }^{\prime}\right)$ is estimated from

$$
\tau_{0}^{\prime}=\frac{\gamma v^{2}}{590.0928}\left(\frac{d_{l}}{H_{1}}\right)^{\frac{1}{3}},
$$

where

$v \quad=$ the flow velocity $(\mathrm{m} / \mathrm{s})$.

The constant $590.0928\left(\mathrm{~m} / \mathrm{s}^{2}\right)$ is provided in Laursen's work (1958). The critical tractive force $\tau_{c}$ is expressed as

$$
\tau_{c}=\phi\left(\gamma_{2}-\gamma\right) d_{1},
$$

where

$$
\phi=\text { the Shields factor (Laursen, 1958). }
$$


This latter force represents the limit below which particles of size class $i$ will not move. In RIVER-RAD, values for the parameters $w_{a}$ and $\phi$ are computed by use of cubic splines that were fit to curves given in Fields (1976) and Bagnold (1966), respectively. (The user can input an overriding value for $w_{a}$ if so desired.) Laursen's function $f$ is also computed by use of a cubic spline that was fit to the curve given in Laursen (1958). Only one size sediment class $i$ is allowed by the model. Thus, the only parameters required by RIVER-RAD to use Laursen's formula to calculate sediment concentration are $d_{i}, s$, and $\gamma_{s}$. Typical values for these parameters can be found in McDowell-Boyer and Hetrick (1982). All other parameters needed, such as water depth, $H_{1}$, and river velocity, $v$, are always input to RIVER-RAD whether or not Laursen's formula is used.

\section{STRUCTURE OF THE RIVER-RAD PROGRAM}

This section presents the overall structure of the RIVER-RAD computer program and summarizes each routine in the code. The listing of the program can be found in Appendix A.

\subsection{SUBROUTINE STRUCTURE}

RIVER-RAD consists of 17 routines in all, 10 that were adapted from the TOXSCREEN model (Hetrick and McDowell-Boyer, 1984) and 7 that were modified from the MLSOIL model (Sjoreen et al., 1984). The logical structure of RIVER-RAD is diagrammed in Fig. 2. The MAIN program calls subroutine READIN to read the input data, initializes variables needed later, and calls subroutine EXEC to begin execution. If the settling velocity is not known and left as blank or 0.0 in the input data, READIN will call subroutine VFALL to compute it, given the median sediment diameter in the river bed. EXEC first determines if the suspended sediment concentrations for the river are input or calculated using Laursen's formula. If the sediment concentrations have not been input, EXEC calls SEDCON, which in turn calls FUNLAU and SPLEVA, to compute them. Subroutine ALPHA is called by EXEC to compute the dissolved and adsorbed fractions for each radionuclide for both the water column and the sediment layer in the river [see Eqs. (3)-(6)]. EXEC then calls the WATER routine, which passes the source, the initial conditions, the removal rates, and the time step to the DECSRC subroutine, which makes calls to MATACT and its functions (ADDEPS, CPROD, PRODUC, VPRDUC, and CVPRD) to calculate radiologic decay and buildup. These calculations are done for one river reach at a time. Each decay chain is also done separately (i.e., one system of equations). However, results for the same nuclides from different decay chains are added together in the model. The resulting activities of each nuclide in each river reach (for both the water column and sediment layer) are stored in COMMON and the EXEC subroutine calls OUTPUT to write out the results.

The system of equations [Eqs. (1) and (2)] is formulated on a monthly basis, that is, the source terms for the parent radionuclides and the water velocity of the river are input as monthly values. All other input parameters are constant. However, since the equations of the model are written with an explicit time step, a 1-day time step is used in the model to increase accuracy. The output of the model contains end-of-the-month values of radionuclide activities in dissolved, adsorbed, and total form for both the water and sediment compartments 
for each reach of the river. The monthly results for volatilization represent the summation of results of the 1-day time steps. More details on the output are given in Sect. 5.

ORNL.DWG 92M.12379

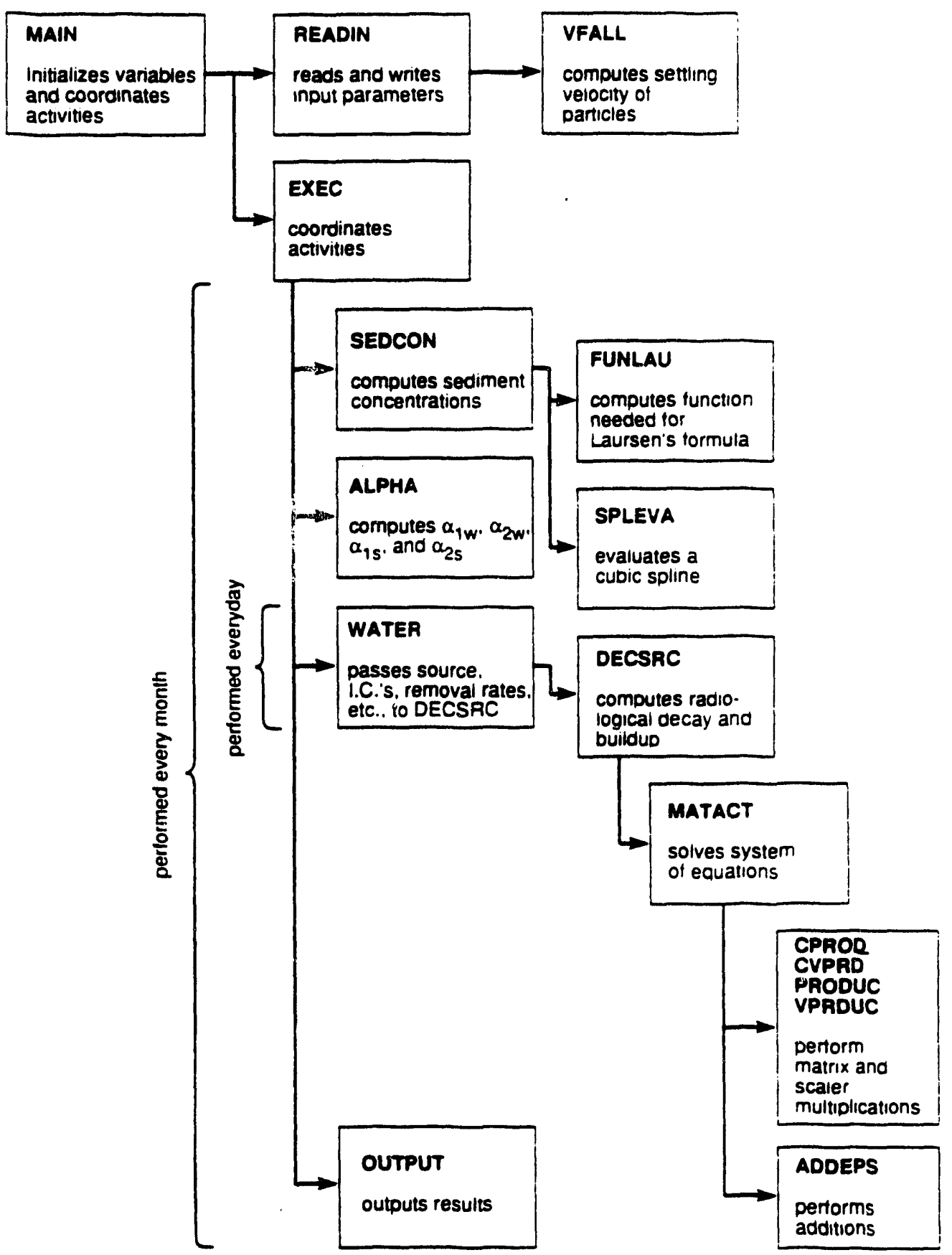

Fig. 2. Structure of RIVER-RAD program. 


\subsection{SUBPROGRAM DESCRIPTIONS}

The RIVER-RAD subroutines are discussed below (in alphabetical order after the MAIN program). If the user desires more details about the code, Appendix B provides a list and description of important parameters in the code, in alphabetical order.

\subsection{The MANN Program}

The MAIN program of RIVER-RAD calls the subroutine READIN to read the input data. Parameters needed by the model are initialized to 0.0 and stored in COMMON to be passed to other subroutines. Then MAIN calls subroutine EXEC to start the simulation.

\section{Subroutine ALPHA}

Subroutine ALPHA computes the fractions in the dissolved $\left(\alpha_{1 w}\right.$ and $\left.\alpha_{1 s}\right)$ and sorbed $\left(\alpha_{2 w}\right.$ and $\left.\alpha_{2 s}\right)$ forms of each radionuclide [see Eqs. (3)-(6)]. ALPHA computes and stores these fractions separately for each parent radionuclide and its daughters.

\section{Subroutine DECSRC}

DECSRC organizes the decay data and removal rates into a matrix array that is passed to subroutine MATACT to solve the system of differential equations described by Eqs. (1) and (2). The resulting activities for all radionuclides and daughters are stored for both the water and sediment compartments. The results are summed by nuclide, regardless of the chains to which they belong. This subroutine was adapted for RIVER-RAD from the MLSOIL computer code (Sjoreen et al., 1984).

\section{Subroutine EXEC}

EXEC is the main connecting link between the major routines SEDCON, ALPHA, WATER, and OUTPUT. The number of time steps (NSTEPS) per month used by the model is set in this subroutine. In the present version, NSTEPS is 30, implying 1-day time steps. If monthly sediment concentrations for the river are not input by the user, subroutine SEDCON is called to compute them. EXEC then calls ALPHA (once per month) to compute the fractions for the dissolved and sorbed forms of each radionuclide for the water and sediment compartments. Subroutine WATER is called every time step to compute the activities for the radionuclides in each reach of the river, again for both the water and sediment compartments. Finally, subroutine OUTPUT is called at the end of EXEC (once per month) to write end of the month results to an output file.

\subsection{Subroutine FUNLAU}

This subprogram is used to compute Laursen's function and other parameters needed for computing sediment concentration in the river by Laursen's formula. The Shields factor, $\phi$, is computed based on the sediment particle diameter, $d$. This factor is computed by SPLEVA (see Sect. 3.2.10), which performs a cubic spline interpolation. The curve used for $\phi$ is from Bagnold (1966). The coefficients of the cubic spline were computed separately for the curve and appear in DATA statements in FUNLAU. In other words, FUNLAU passes 
$d$ and the appropriate coefficients to FUNCTION SPLEVA, and $\phi$ is computed. The critical tractive force [Eq. (10)] is then computed using $\phi$, the water density, the sediment density, and $d$. The independent variable needed for Laursen's function [Eq. (8)] is computed using the settling velocity $w_{a}$ (see subroutine VFALL below), the acceleration of gravity, and input parameters for water depth and river slope. Finally, Laursen's function is computed by use of a cubic spline that was fit to the curve given by Laursen (1958). These results are passed back to subroutine SEDCON, where the sediment concentration is computed.

\subsubsection{Subroutine MATACT}

MATACT solves the system of linear ordinary differential equations defined in Eqs. (1) and (2) using matrix methods to obtain the activity of each nuclide. The solution is based on the method described in Sjoreen et al. (1984). Four subroutines, CPROD, PRODUC, VPRDUC, and CVPRD, are called by MATACT to perform matrix and scalar multiplication of matrices and vectors. Function ADDEPS is used to perform additions; an addition is set to zero if it is less than machine epsilon to prevent loss of significance errors.

\subsection{Subroutine OUTPUT}

The sole purpose of subroutine OUTPUT is so rite out results from the RIVER-RAD calculations to a file named OUTPUT.RIV. More details about the output are given in Sects. 4 and 5.

\subsection{Subroutine READIN}

The READIN subroutine reads the input data for the RIVER-RAD model from two files: RADIO.IN and WATER.IN. These input data are discussed thoroughly in the next section. After reading the data, READIN outputs the data into the file OUTPUT.USR. This helps the user determine whether the data were input correctly. Where appropriate, various warning messages are written into this file if the program can recognize that the data are incorrect or illogical. See Sect. 5 on output for further discussion of this file.

READIN has the option to call subroutine VFALL if the settling velocity (parameter SETVEL) is not known and is left blank or set to 0.0 by the user in input file WATER.IN. READIN calls VFALL to compute the settling velocity given the median sediment diameter.

\section{Subroutine SEDCON}

This subroutine is an optional routine that can be used to compute suspended sediment concentrations for the river if these values are unknown. Values for the median sediment diameter of the river bed, sediment density, water density, avcrage depth, and slope of the river must be input in READIN to use SEDCON. SEDCON will call FUNLAU (see Sect. 3.2.5) to assist in computing the sediment concentration of the river using Laursen's formula (Laursen, 1958). 


\section{Function SPLEVA}

The sole purpose of SPLEVA is to evaluate a cubic spline function using Horner's rule (Forsythe et al., 1977). SPLEVA is used by both subroutine SEDCON and FUNLAU.

\section{Subroutine VFALL}

This subroutine is used to compute the sediment fall or settling velocity, $w_{a}$, based on the median sediment diameter $d$. A cubic spline interpolation is performed by SPLEVA in this computation. The curve used for the fall velocity is from Fields (1976). The coefficients of the cubic spline were computed separately for the curve and appear in DATA statements in VFALL (i.e., VFALL passes $d$ and the cubic spline coefficients for the curve to FUNCTION SPLEVA, and $w_{0}$ is calculated).

\subsection{Subroutine WATER}

This subprogram passes the radionuclide source term (parent radionuclides into first reach of river only), the removal rates for each radionuclide from one reach to the next plus the volatilization rate, the removal rate of each radionuclide from the water compartment due to settling, the removal rate from the sediment compartment due to iesuspension and sedimentation, and the initial activities of the nuclides for each reach (for each time step one each at a time) to subroutine DECSRC, where the decay and daughter ingrowth are (4) Ulated. Upon return from DECSRC, the activities for each reach are stored to be used as the initial activities for the next time step and for flow from reach to reach. Likewise, the sctivities of the radionuclides in the sediment compartment below each reach are stored. Also, the volatilization from the river is summed from all reaches for each month and stored.

\section{RIVER-RAD OPERATION}

This section presents the necessary information on how to run the RIVER-RAD computer code. A complete discussion of input data is included. While reading this section, it will be helpful to refer to Appendix $\mathrm{C}$, which contains sample input data.

\subsection{MODE OF OPERATION}

Before the execution of RIVER-RAD is possible, the user must first prepare two input data files: RADIO.IN and WATER.IN. These files are requested by OPIEN statements within the code. RADIO.IN contains the listing of the parent radionuclides and their daughters, as well as their decay matrices (cee Appendix C). This file is provided to the user with the code, but instructions will be given here $s 0$ that the user can modify' RADIO.IN if necessary. WATER.IN includes information, such as the number of years the user wants the simulation to run, the names and source terms of the parent nuclides, the river water velocity, the dimensions for the reaches, the volatilization rates and distribution coefficients $K_{d}$ for the radionuclides, and the sediment parameters (sce Appendix C). These files are described in detail below. 
During execution, KIVER-RAD writes results into two files: OUTPUT.USR and OUTPUT.RIV (these filc's are also specified by OPEN statements in the code). These output files are discussed further in Sect. 5.

RIVER-RAD has been run on several different computers, including IBM compatible PC's (286, 386, and 486), an IBM RISC 6000, and a VMS VAX 8600. The following section discusses in detail how the input data should be constructed by the user.

\section{INPUT DATA}

Tables 1 and 2 will aid the user in preparing the input files WATER.IN and RADIO.IN, respectively. Three types of standard FORTRAN format codes appear in Tables 1 and 2: the $A, E$, and I formats. The $A$ format code is used in transmitting data the in character format, the $\mathrm{E}$ format code is used in transmitting real data, and the I format code is for integer data. For the $\mathrm{E}$ and I formats, leading, embedded, and trailing blanks in a field of the input card are interpreted as zeros. In $\mathbf{E}$ format, if the decimal point is present, its position overrides the position indicated by the $d$ portion of the format field descriptor (Ew.d), and the number of positions specified by the $w$ portion of this field must include a place for it. For $\mathrm{E}$ formats, the $\mathrm{E}$ may be omitted from the exponent if the exponent is signed (i.e., 1.0E+1 may be typed $1.0 \div 1$ ).

Table 1 is used to prepare file WATER.IN. Note that the names of the parent radionuclides (parameter NUC, card set 3, Table 1) in file WATER.IN n. ust be read exactly as they appear in file RADIO.IN (see parameter DAUGHTER, card 2, Table 2). The code reads the parent nuclide name NUC from file WATER.IN, then searches file RADIO.IN for the same name in order to retrieve names of the daughters as well as the decay data. In the example files given in Appendix C, the names of the radionuclides are left justified in the field of character format A8. The nuclide names are given as isotope symbols (e.g., SR-90, Y-90, etc.). Also, in file WATER.IN, the first 20 columns of each line are reserved for comments, such as the name(s) of the parameter(s) that is(are) included on that line (e.g., see the file in Appendix C).

For the volatilization rate, $k_{v}$, and the soil-water distribution coefficient, $k_{d}$ (Table 1 , card set 8), the values of the parent are given first, followed by values for each of the daughters given in the orcher that they are read (see Table 2, card 2!. -If more than one parent is desired in a simuliktion, then values for $k_{v}$ and $k_{d}$ are given for parent number 1 (see Table 1, card set 3) and its daughters first, followed by parent number 2 and its daughters, etc. Values are always given for each daughter, even if a daughter had appeared previously for another parent. Note that data for $k_{v}$ and $k_{d}$ are not given for short-lived daughters.

The user has the option of either entering the settling velocity $w_{a}$ (Table 1, card set 11) or leaving it blank or 0.0 and the code will compute it via subroutine VFALL. In either case, the parameter (SETVEL) is written to file OUTPUT.RIV. 
Table 1. Water parameters input sequence (file WATER.IN)

\begin{tabular}{|c|c|c|c|c|c|c|}
\hline $\begin{array}{l}\text { Cnd } \\
\text { ad }\end{array}$ & Fonmen & Parmer & Type & $\begin{array}{l}\text { Colmena } \\
\text { porinion }\end{array}$ & Units & $\begin{array}{l}\text { Definitions } \\
\text { and commense }\end{array}$ \\
\hline 1 & $(28 \times, 12)$ & JYRS & Integer & $\begin{array}{c}29.30 \\
\text { (Right justified) }\end{array}$ & $(-)$ & $\begin{array}{l}\text { Number of yearn to be } \\
\text { simulated; limited to } 10 \\
\text { due to dimensioning }\end{array}$ \\
\hline 2 & $(28 \times, 12)$ & NNUC & Integer & $\begin{array}{c}29-30 \\
\text { (Right juatified) }\end{array}$ & $(-)$ & $\begin{array}{l}\text { Number of parent radio- } \\
\text { nuclides to be simulated; } \\
\text { limited to } 10 \text { due to } \\
\text { dimensioning }\end{array}$ \\
\hline
\end{tabular}

Card Set 3 ts repeated for each parent nuclide (i.e, enter the name for nuclide I=1 on line 3, I $=2$ on the nent line, ete)

\begin{tabular}{|c|c|c|c|c|c|c|}
\hline 3 & (20X,AB) & $\begin{array}{c}\text { NUC (I) } \\
(I=1, \text { NNUC) }\end{array}$ & Cuarncter & 21.28 & $(-)$ & $\begin{array}{l}\text { Radionuclide name of } \\
\text { parent nuclide } I=1 \text {. Enter } \\
\text { NNUC lines }\end{array}$ \\
\hline
\end{tabular}

Set 4 is repeated for each year and radionuclide. The source for parent $I=1$ is entered on two lines for year $\mathrm{MR}=1$, the aent two lines for $\mathrm{IYR}=2$, etc for JYRS. The source for radionuclide $I=2$ would follow, with data for each year on 2 lines. Repeat for NNUC parents. Soe Appendts C for ecamples.

\begin{tabular}{|c|c|c|c|c|c|c|}
\hline (line 2) & $(200 \times, 6 E 10.3)$ & $\begin{array}{c}\text { WQTNR } \\
\text { (I,MON,IYR) }\end{array}$ & Real & $\begin{array}{c}21-30 \mathrm{I}=1, \mathrm{MON}=1, \mathrm{IYR}=1 \\
31-40 \mathrm{I}=1, \mathrm{MON}=2, \mathrm{IYR}=1 \\
\cdot \\
71-0 \mathrm{I}=1, \mathrm{MON}=6, \mathrm{IYR}=1 \\
21-30 \mathrm{I}=1, \mathrm{MON}=7, \mathrm{IYR}=1 \\
\dot{\cdot} \\
71-80 \mathrm{I}=1, \mathrm{MON}=12, \mathrm{IYR}=1\end{array}$ & Ciks & $\begin{array}{l}\text { Radionuclide source rate } \\
\text { into reach } 1 \text { of the river } \\
\text { for parent } 1 \text {, month MON } \\
\text { and year IYR. MON=1 } \\
\text { signifies the month } \\
\text { October }\end{array}$ \\
\hline$\stackrel{5}{5}$ & $(20 \times, 6 \mathrm{E} 10.3)$ & $\begin{array}{c}\text { WVELR } \\
\text { (MON,IYR) }\end{array}$ & Real & $\begin{array}{c}21-30 \text { for } M O N=1, I Y R=1 \\
31-40 \text { for } M O N=2, I Y R=1 \\
\cdot \\
\cdot \\
71-0 \text { for } M O N=6, I Y R=1\end{array}$ & $\mathrm{~m} / \mathrm{s}$ & $\begin{array}{l}\text { The average water velocity } \\
\text { of the river for month } \\
\text { MON and year IYR. } \\
\text { Repeat Set } 5 \text { for each yea } \\
\text { for JYRS years }\end{array}$ \\
\hline$\stackrel{5}{\text { (line 2) }}$ & $(20 \times, 6 \mathrm{E} 10.3)$ & $\begin{array}{c}\text { WVELR } \\
\text { (MON,IYR) }\end{array}$ & Real & $\begin{array}{c}21-30 \mathrm{fx} M O N=7, T Y R=1 \\
\text { 71-80 for } \mathrm{MON}=12, I Y R=1\end{array}$ & $\mathrm{~m} / \mathrm{s}$ & \\
\hline 6 & $(28 x, 12)$ & $\mathbf{N R}$ & Integer & $\begin{array}{c}29-30 \\
\text { (Right justified) }\end{array}$ & $(-)$ & $\begin{array}{l}\text { Number of reaches that } \\
\text { river is broken into; } \\
\text { limited to } 20 \text { due to } \\
\text { dimenaioning }\end{array}$ \\
\hline
\end{tabular}


Table 1 (continued)

\begin{tabular}{|c|c|c|c|c|c|c|}
\hline $\begin{array}{l}\text { Cand } \\
\text { end }\end{array}$ & Forment & $\begin{array}{c}\text { Parnmeter } \\
\text { mane }\end{array}$ & Type & $\begin{array}{l}\text { Columnn } \\
\text { position }\end{array}$ & Units & $\begin{array}{l}\text { Definitions } \\
\text { and comments }\end{array}$ \\
\hline \multirow[t]{3}{*}{7} & $(20 \times, 3 E 10.3)$ & WLENR & Real & $21-30$ & $\mathbf{m}$ & $\begin{array}{l}\text { Length of each river reach } \\
\text { (all reaches have same } \\
\text { dimensions) }\end{array}$ \\
\hline & & WWIDR & Real & $31-40$ & $\mathbf{m}$ & Average width of the river \\
\hline & & WDEPR & Real & $41-50$ & $\mathbf{m}$ & Average depth of the river \\
\hline
\end{tabular}

Repeat set 8 for each parent and its daughters for each chain I. There are SIZE(1)+SIZE(2) $+\ldots+$ SIZE(NNUC) lines in this set.

\begin{tabular}{|c|c|c|c|c|c|c|}
\hline 8 & $(20 \times, 2 E 10,3)$ & $\begin{array}{c}\text { WKVR } \\
\text { (J, I) } \\
I=1, \text { NNUC } \\
\mathrm{J}=1 \text {, SIZE (I) } \\
\text { (see Table } 2 \\
\text { for definition } \\
\text { of SIZE) }\end{array}$ & Real & $21-30$ & $8^{-1}$ & $\begin{array}{l}\text { Volatilization rate constant } \\
\text { for daughter } J \text { of parent I } \\
(J=1 \text { is parent and } J=2 \text {, } \\
\text { SIZE (I) are daughters). } \\
\text { See Sect. } 4.2 \text { for more } \\
\text { details }\end{array}$ \\
\hline & & $\begin{array}{c}\text { SWKDR } \\
(J, I) \\
I=1, \text { NNUC } \\
J=1, \text { SIZE (I) }\end{array}$ & Real & $31-40$ & $\begin{array}{l}\text { (atoms/g) I } \\
\text { (atoms/mL) }\end{array}$ & $\begin{array}{l}\text { Soil-water distribution } \\
\text { coefficient for parent I, } \\
\text { daughter J (see } \\
\text { explanation for WKVR) }\end{array}$ \\
\hline 9 & $(26 \times, A 4)$ & SEDRIV & Character & $\begin{array}{c}27-30 \\
\text { (Right justified) }\end{array}$ & $(-)$ & $\begin{array}{l}\text { If total suspended } \\
\text { sediment concentration in } \\
\text { the river is known, type } \\
\text { YES in columns 28-30; } \\
\text { otherwise, type NO in } \\
\text { columns 29-30 }\end{array}$ \\
\hline
\end{tabular}

If SEDRIV is YES, then card set 10 is:

\begin{tabular}{|c|c|c|c|c|c|c|}
\hline $\begin{array}{c}10 \\
\text { (line 1) }\end{array}$ & $(20 \mathrm{X}, 6 \mathrm{E} 10.3)$ & $\begin{array}{c}\text { SEDCR } \\
\text { (MON, IYR) }\end{array}$ & Real & $\begin{array}{c}21-30 \text { for } M O N=1, I Y R=1 \\
31-40 \text { for } M O N=2, I Y R=1 \\
\text { t1 } 80 \text { for } M O N=6, I Y R=1\end{array}$ & $\mathrm{~kg} / \mathrm{m}^{3}$ & $\begin{array}{l}\text { Average suspended } \\
\text { sediment concentration in } \\
\text { river for month MON and } \\
\text { year IYR. Repeat Set } 10 \\
\text { for each year for JYRS } \\
\text { years. MON = } 1 \text { signifies } \\
\text { month of October }\end{array}$ \\
\hline $\begin{array}{c}10 \\
\text { (line 2) }\end{array}$ & $(20 X, 6 \mathrm{E} 10.3)$ & $\begin{array}{c}\text { SEDCR } \\
\text { (MON, IYR) }\end{array}$ & Real & $\begin{array}{c}\text { 21-30 for } \mathrm{MON}=7, \mathrm{IYR}=1 \\
\cdot \\
71-80 \text { for } \mathrm{MON}=12, \mathrm{IYR}=1\end{array}$ & & \\
\hline
\end{tabular}


Table 1 (continued)

If SEDRIV is NO, then card set 10 is as follows (only one line):

\begin{tabular}{|c|c|c|c|c|c|c|}
\hline $\begin{array}{l}\text { Card } \\
\text { set }\end{array}$ & Format & $\begin{array}{l}\text { Parameter } \\
\text { name }\end{array}$ & Type & $\begin{array}{l}\text { Column } \\
\text { postion }\end{array}$ & Units & $\begin{array}{l}\text { Definitions } \\
\text { and comments }\end{array}$ \\
\hline \multirow[t]{3}{*}{10} & $(20 \times, 3 E 10.3)$ & DENSDR & Real & $21-30$ & $\mathrm{~g} / \mathrm{cm}^{3}$ & Sediment density in river \\
\hline & & DENWR & Real & $31-40$ & $g / \mathrm{cm}^{3}$ & Water density \\
\hline & & SLOPER & Real & $41-50$ & $(-)$ & Slope of river bed \\
\hline
\end{tabular}

For card set 11, typical values can be found in Ditoro et al. (1981).

\begin{tabular}{|c|c|c|c|c|c|c|}
\hline \multirow[t]{6}{*}{11} & $(200 \times, 6 \mathrm{E} 10.3)$ & DIASDR & Real & $21-30$ & $\mathbf{m m}$ & Median sediment diameter \\
\hline & & SEDCS & Real & $31-40$ & $\mathrm{~kg} / \mathrm{m}^{3}$ & $\begin{array}{l}\text { Solids concentation in } \\
\text { sediment layer }\end{array}$ \\
\hline & & SDEPR & Real & $41-50$ & $\mathbf{m}$ & Depih of sediment layer \\
\hline & & RESVEL & Real & $51-60$ & $\mathrm{~mm} / \mathrm{yr}$ & $\begin{array}{l}\text { Sediment resuspension } \\
\text { velocity }\end{array}$ \\
\hline & & SEDVEL & Real & $61-70$ & $\mathbf{m m} / \mathbf{y r}$ & $\begin{array}{l}\text { Sedimentation velocity } \\
\text { from bottom of sodiment } \\
\text { lyyer }\end{array}$ \\
\hline & & SETVEL & Real & $71-80$ & $m / s$ & $\begin{array}{l}\text { The settling velocity (if } \\
\text { left blank or } 0.0, \text { VFALL } \\
\text { subroutine used to } \\
\text { compute it) }\end{array}$ \\
\hline
\end{tabular}


Table 2. Nuclides Decay Data Parameters Input Sequence (file RADIO.IN)

\begin{tabular}{|c|c|c|c|c|c|c|}
\hline $\begin{array}{l}\text { Cand } \\
\text { ent }\end{array}$ & Formnt & $\begin{array}{l}\text { Parameter } \\
\text { anme }\end{array}$ & Type & $\begin{array}{l}\text { Column } \\
\text { ponition }\end{array}$ & Units & $\begin{array}{l}\text { Definition } \\
\text { and comments }\end{array}$ \\
\hline \multirow[t]{2}{*}{1} & (2I3) & $\operatorname{SIZE}(I)$ & Integer & $\begin{array}{c}1-3 \\
\text { (Right justified) }\end{array}$ & $(-)$ & $\begin{array}{l}\text { The length of the } \\
\text { radionuclide chain. } \\
\text { Includes the parent plus } \\
\text { the number of daughters. } \\
\text { I is the index for the chain }\end{array}$ \\
\hline & & NEXTRA(I) & Integer & $\begin{array}{c}4-6 \\
\text { (Right justified) }\end{array}$ & $(-)$ & $\begin{array}{l}\text { The number of short-lived } \\
\text { daughters for chain I }\end{array}$ \\
\hline 2 & $(1 X, 8(A B, 2 X))$ & $\begin{array}{c}\text { DAUGH- } \\
\text { TER } \\
(\mathrm{J}, \mathrm{I}) \\
\mathrm{J}=1, \text { SIZE (I) }\end{array}$ & Character & $\begin{array}{c}2-9 \text { for } J=1 \\
10-17 \text { for } J=2 \\
18-25 \text { for } J=3 \\
\text { etc. }\end{array}$ & $(-)$ & $\begin{array}{l}\text { The names of parent and } \\
\text { its daughters. I is the } \\
\text { index for the chain; } J=1 \text { is } \\
\text { the index for the parent } \\
\text { and } J=2 \text { to SIZE (I) are } \\
\text { indices for daughters }\end{array}$ \\
\hline
\end{tabular}

If NEXTRA (I) is not 0 , then the following card is read for each short-lived daughter for chain I just read (if NEXTRA (I) is 0 then skip the next line):

\begin{tabular}{|c|c|c|c|c|c|c|}
\hline 3 & $(\mathbf{A B}, \mathbf{1 3})$ & $\begin{array}{c}\text { EXNAME } \\
(\mathrm{J}, \mathrm{I}) \\
\mathrm{J}=1 \\
\text { NEXTRA(I) }\end{array}$ & Character & 18 & $(-)$ & $\begin{array}{l}\text { Name of short-lived } \\
\text { daughter for chain I. If } \\
\text { NEXIRA > 1, next line } \\
\text { would contain name of } \\
\text { second short-lived } \\
\text { daughter, etc. }\end{array}$ \\
\hline & & $\begin{array}{c}\text { PARNUM } \\
(J, I) \\
\text { J=1, } \\
\text { NEXTRA (I) }\end{array}$ & Integer & $\begin{array}{c}9-11 \\
\text { (Right justified) }\end{array}$ & $(-)$ & $\begin{array}{l}\text { Number of the index in } \\
\text { parameter DAUGHTER } \\
\text { that is parent for short- } \\
\text { lived daughter } \\
\text { EXNAME(J,I) }\end{array}$ \\
\hline 4 & (8E10.3) & $\begin{array}{c}\text { DECAY } \\
(\mathrm{K}, \mathrm{J}, \mathrm{I}) \\
\mathrm{J}=1, \operatorname{SIZZ}(\mathrm{I}) \\
\mathrm{K}=1, \operatorname{SIZE}(\mathrm{I})\end{array}$ & Real & $\begin{array}{c}1-10 \text { for } \mathrm{J}=1, \mathrm{~K}=1 \\
11-20 \text { for } \mathrm{J}=1, \mathrm{~K}=2 \\
\text { etc. for } \mathrm{SIZE}(\mathrm{I}) \\
\text { lines of matrix }\end{array}$ & & $\begin{array}{l}\text { Decay matrix for chain I } \\
\text { (see Sect. } 4.2 \text { ). There are } \\
\text { SIZE(I) lines in this set }\end{array}$ \\
\hline
\end{tabular}


The decay matrix (Table 2, card set 4 ) is defined as follows:

$$
\begin{aligned}
& a_{11}=-\lambda_{l}, \\
& a_{l j}=\lambda_{l} b_{l j},
\end{aligned}
$$

where

$\lambda_{i}=$ the decay constant for nuclide $i$ in $s^{-1}$. The decay constant $=\ln (2) /$ half-life.

$b_{i j}=$ the branching fraction from nuclide $j$ to nuclide $i$ (unitless).

The matrix is lower triangular. Decay data for short-lived daughters are omitted from the decay matrices because their activity is set equal to that computed for their parent (see card set 3 of Table 2).

\section{DESCRIPTION OF CODE OUTPUT}

This section gives a detailed description of what is written into the two output files OUTPUT.USR and OUTPUT.RIV. The reader is referred to Appendix D, which contains the RIVER-RAD output that was written during execution of the code using the sample input ¿..:a from Appendix $C$.

\subsection{RESULTS WRITTEN TO OUTPUT.USR}

The input data to RIVER-RAD are written to file OUTPUT.USR so that the user can determine if they were input correctly. The input parameter names, the definitions, the units, and the values for the parameters are listed in this file. The file includes a listing of the daughters for the parent nuclides (the parent names come from file WATER.IN, and the daughters of the parents sre read from RADIO.IN). The model flag (SEDRIV) that the user inputs to determine wheiher the suspended sediment concentrations of the river are either input directly or are calculated in the model is listed, and the option chosen is explained. Following the definitions of the parameters, a table is printed showing the monthly magnitudes of the source terms for each of the parent nuclides.

Where feasible, the RIVER-RAD computer code checks the input data, and if an error (an obviously illogical value or choice) is detected, a message is printed into file OUTPUT.USR and execution stops. For example, if the parameter NUC(I) (Table 1, card set 3) is not input correctly so that it will match the parameter DAUGHTER(1,I) (Table 2, card 2), the following message will appear: "NUCLIDE NOT IN DATABASE STOP", where is the name that the user typed for parameter NUC in WATER.IN. Numerous other checks such as this one can be found in the computer program. Also, some checks are made during actual execution of RIVER-RAD (i.e., after the input data are read). If errors are detected, messages will be written into this file. Thus, the user should always check file OUTPUT.USR carefully, especially if execution stops prematurely. 


\subsection{RESULTS WRITTEN TO OUTPUT.RIV}

The calculated monthly radionuclide activities and media interaction terms are printed into a file named OUTPUT.RIV. The contaminated surface area of the river is printed first. Thereafter, for each month, the activity $(\mathrm{Ci})$ for each radionuclide (in the dissolved or neutral form, the adsorbed form, and the total form) is printed for each river reach for both the water and sediment compartments. Also, the media interaction rates in $\mathrm{Ci} / \mathrm{mon}$ are printed for each radionuclide. Note that volatilization is the only interaction term considered in the RIVERRAD model at present. All the other media interaction rates (deposition on water, surface runoff, groundwater runoff, and washload) are assumed to be 0.0 in the present model and are printed as such in OUTPUT.RIV. See Appendix D for examples.

\section{DISCUSSION}

This report has provided a description and subroutine structure of the RIVER-RAD model, input requirements and format, and description of output from the RIVER-RAD computer code. The RIVER-RAD model is a combination of the river portion of the TOXSCREEN program (Hetrick and McDowell-Boyer, 1984), modified to include a sediment compartment, and the routines used to compute radioactive decay and buildup from the MLSOIL model (Sjoreen et al., 1984). Thus, proven routines have been used in the development of RIVER-RAD. All the subprograms of RIVER-RAD have been tested by doing preliminary stand-alone computer runs for each routine. For example, the results computed by subroutine SEDCON were checked by writing a driver routine that supplied SEDCON with the appropriate parameters. Where possible, these results were compared with hand computations.

Once the subroutines were assembled to form RIVER-RAD, numerous additional checks were made to ensure the results were correct. For example, the results for RIVERRAD were compared with TOX-SCREEN results (using the river portion only) for isotopes that had no daughters. The results from the two models matched very closely; note that the solutiinn techniques differ between the two models. To check results for daughters, a "regular" run was performed for an isotope and its daughters, using three river reaches and assuming there was no settling to the sediment compartment (Case 1). The RIVER-RAD program was modified temporarily to take the results for the parent and daughters from Case 1 for the first reach and input these results to the first reach (Case 2). The results for the first reach from Case 2 were found to equal the results from the second reach in Case 1. Also, the model was run to steady state using a constant source term and constant river water velocity. The steady-state results compared closely with the analytical solutions for both the water and sediment compartments. Thus, much effort was put forth in checking and rechecking code calculations.

RIVER-RAD results from the first reach of a river are compared with an analytical equation for ingrowth of activity of a radioactive daughter in Appendix $E$. The code was temporarily modified not to allow any settling to the sediment compartment for these results. 
The equation cannot be compared with model results for downstream reaches below the first reach because these reaches receive daughters.

At present, RIVER-RAD does not include media interaction rates, such as deposition on water, surface runoff, groundwater runoff, and washload. Thus, the only way to input such rates is to include them in the input source term. RIVER-RAD has the capability to easily add media interaction terms if needed.

The input data in Appendix $C$ used for the sample computer runs that produced the output in Appendix D were hypothetical. It was the authors' intent to show the capabilities of the model through use of these examples, not to show an actual application. It is hoped that RIVER-RAD can be used as a screening device in identifying radionuclides that are highly unlikely to pose a problem even under conservative assumptions. 


\section{REFERENCES}

1. R. A. Bagnold, An Approach to the Sediment Transport Problem from General Physics, Geological Survey Professional Paper 422-I, U.S. Government Printing Office (1966).

2. D. M. DiToro, D. J. O'Connor, R. V. Thomann, and J. P. St. John, Analysis of Fate of Chemicals in Receiving Waters - Phase I, HydroQual, Inc., Mahwah, NJ (1981).

3. D. E. Fields, CHNSED: Simulation of Sediment and Trace Contaminant Transport with Sediment/Contaminant Interaction, ORNL/NSF/EATC-19, Oak Ridge National Laboratory (1976).

4. G. E. Forsythe, M. A. Malcolm, and C. B. Moler, Computer Methods for Mathematical Computations, Prentice-Hall, Inc. (1977).

5. D. M. Hetrick and L. M. McDowell-Boyer, User's Manual for TOX-SCREEN: $A$ Multimedia Screening-Level Program for Assessing the Potential Fate of Chemicals Released to the Environment, ORNL-6041, EPA-560/5-83-024, Oak Ridge National Laboratory (1984).

6. E. M. Laursen, The Total Sediment Load of Streams, Paper \#1530 in Proceedings of ASCE 84, HY1 (1958).

7. C. E. Lee, The Calculation of Isotopic Mass and Energy Production by a Matrix Operator Method, LA-6483-MS (1976).

8. L. M. McDowell-Boyer and D. M. Hetrick, A Multimedia Screening-Level Model for Assessing the Potential Fate of Chemicals Released to the Environment, ORNL/TM8334, Oak Ridge National Laboratory (1982)

9. A. L. Sjoreen, D. C. Kocher, G. G. Killough, and C. W. Miller, MLSOIL and DFSOIL - Computer Codes to Estimate Effective Ground Surface Concentrations for Dose Computations, ORNL-5974, Oak Ridge National Laboratory (1984). 


\section{APPENDIX A}

\section{LISTING OF RIVER-RAD}

The MAIN program is given first, followed by the subprograms in alphabetical order.

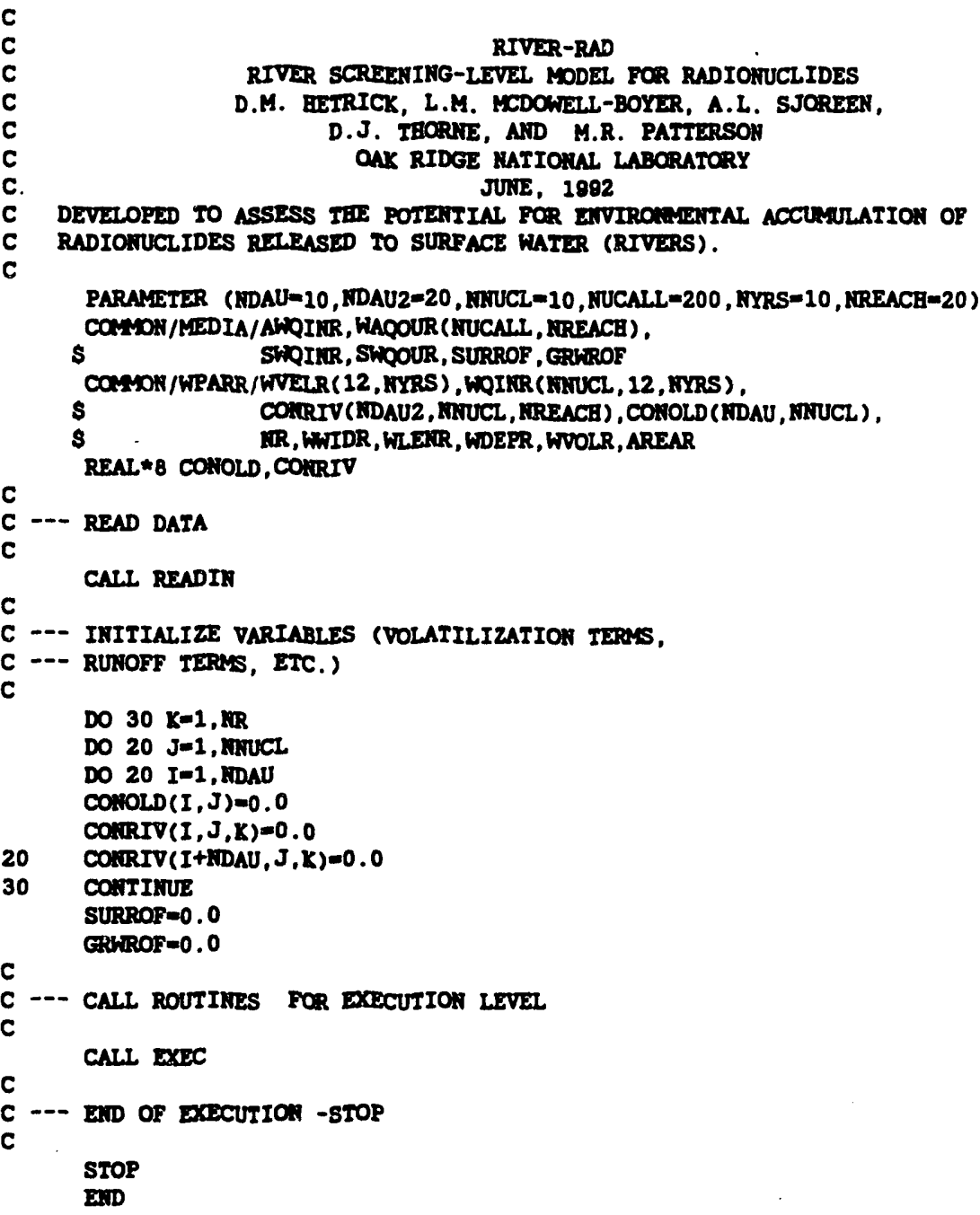




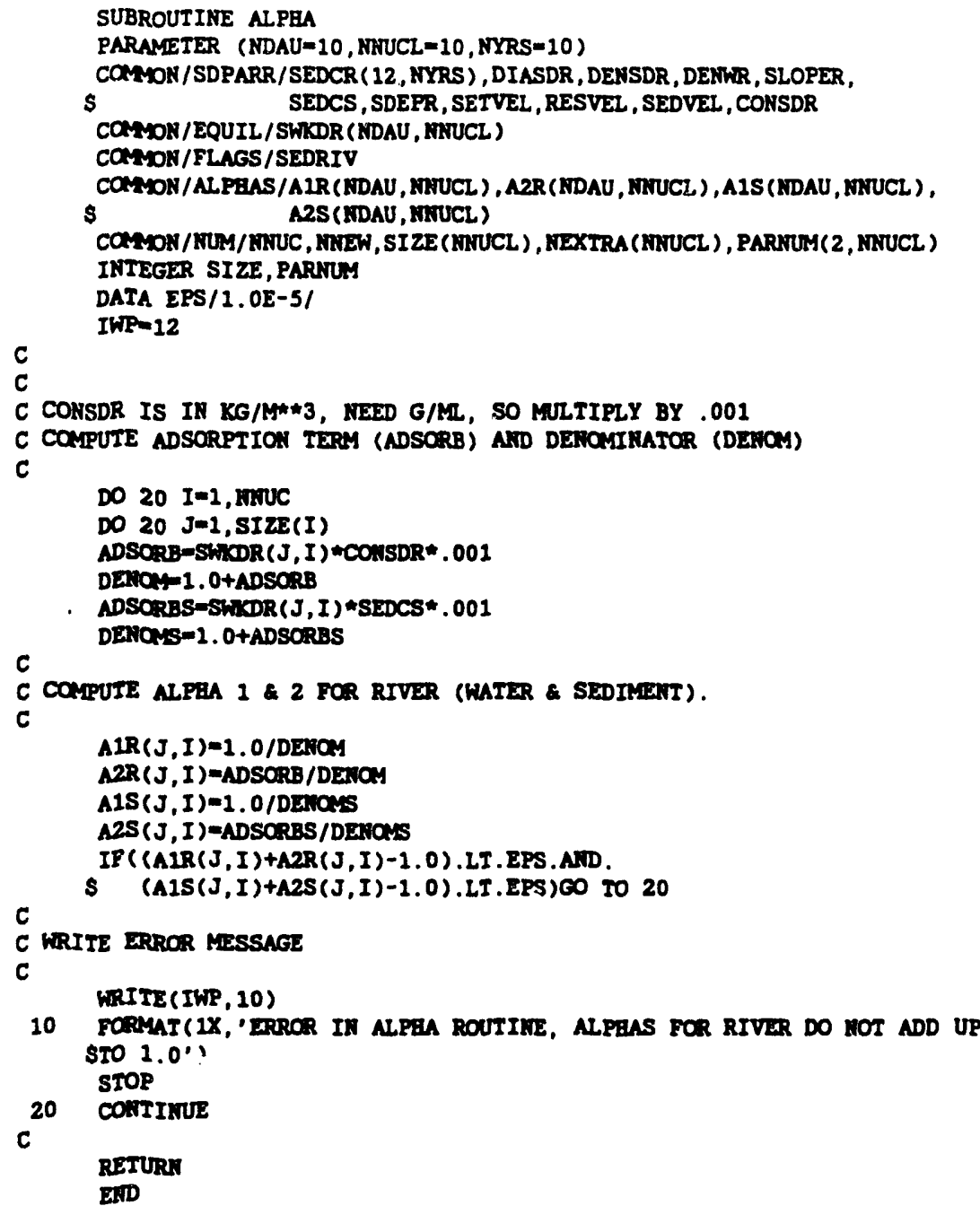


subroutine DECSRC ( $i, k, A O, P, T$ IME, LAMR, ISTEP, NSTEPS , A)

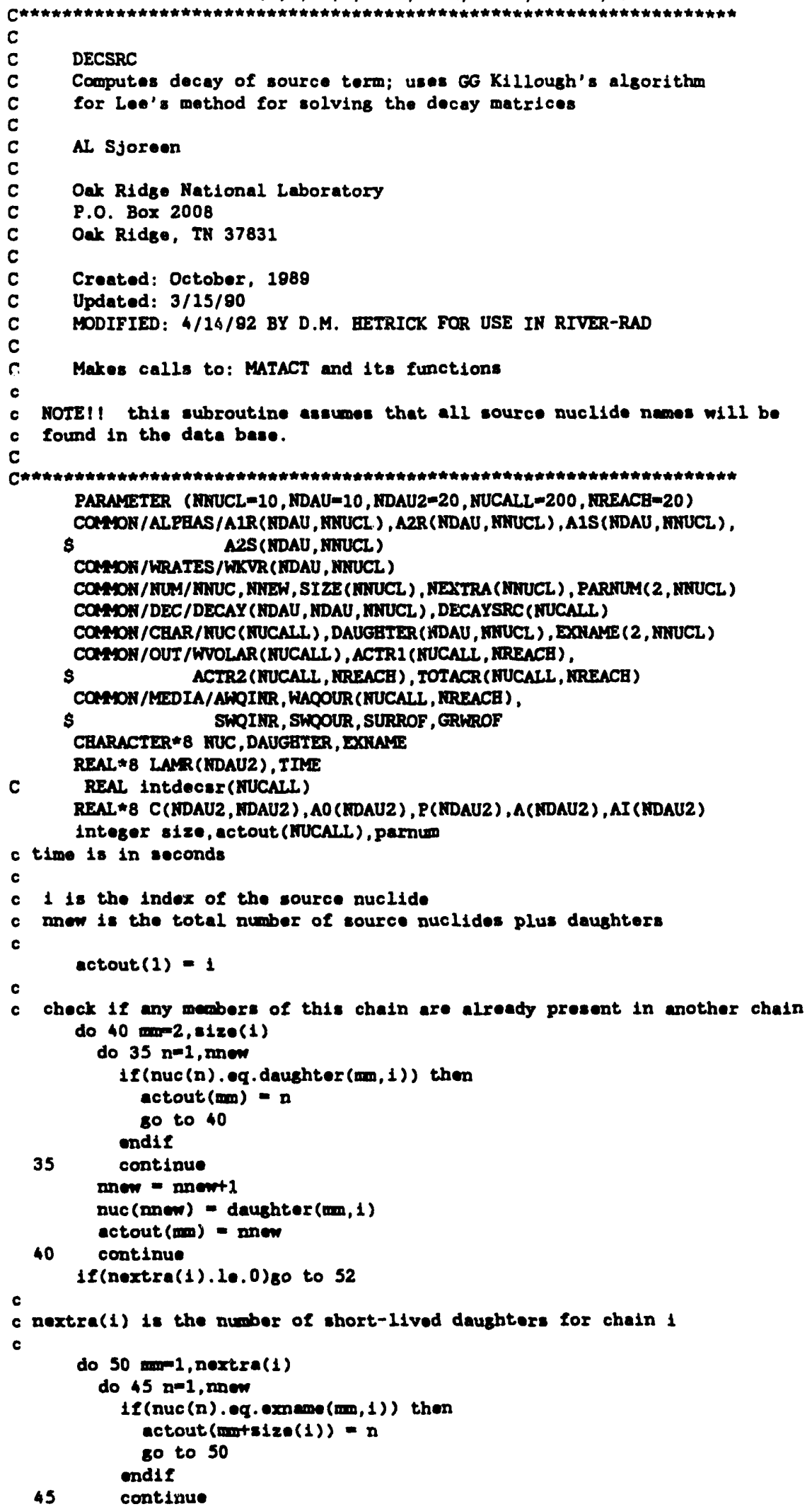




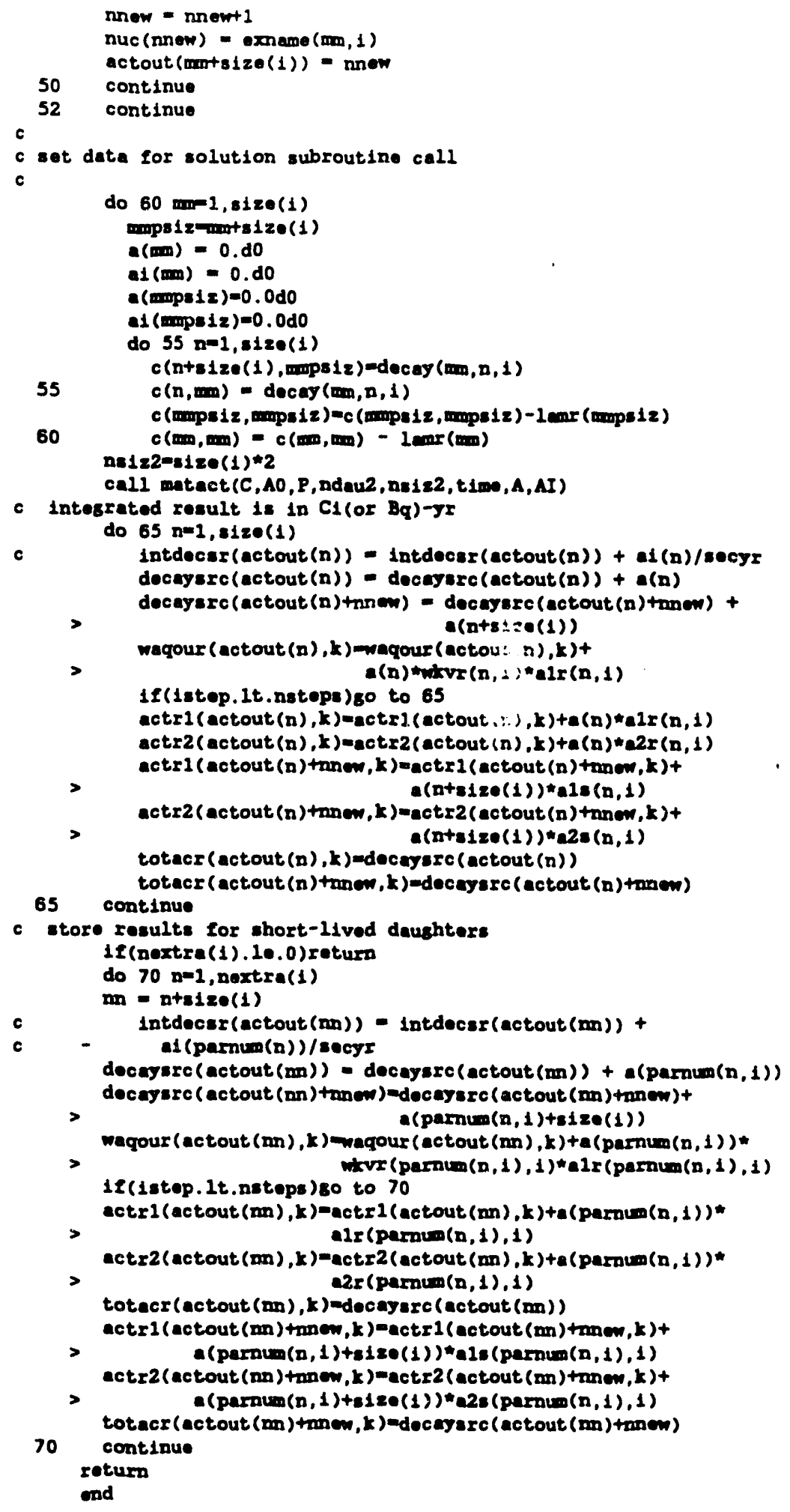




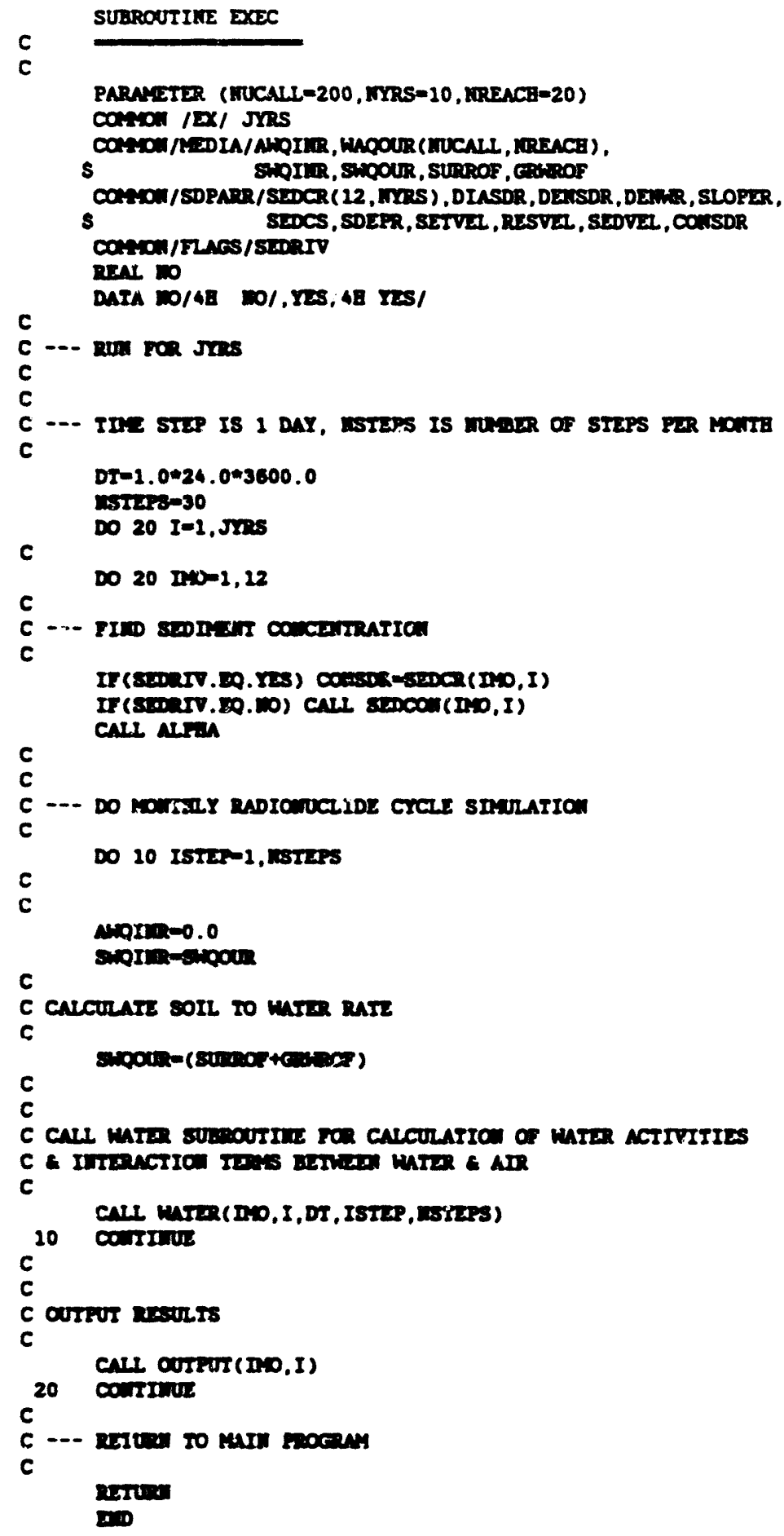


SUBROUTINE FUNLAU (DIASED, DENSED, DENWAT, WDEPTE, SLOPE, TCRIT, RARAIETER (TYRS=10)

COAYON/SDPARR/SEDCR (12, WXRS), DIASDR, DEISDR, DEIWR, SLOPER

$\mathbf{s}$ SEDCS , SDEFR, SEIVEL , RESVEL, SEDVET, CONSDR

C DIMEMSIOA SVEL (26), F(26), BFUNC (26), CFUNC (26), DFUAC (26), DIATEE (22), S SHIELD(22), BTHETA(22), CTHETA(22), DTHIETA(22)

C DIATEE, SAIETD, BTEETA, CTELTA, D DTEETA ARE PARAETISS

C MDEDED IA SPLIRE CALCULATIOA OF SEIBLDS FACTOR (IRITA) BELOA.

c

DATA DIATEE/ $/ 01, .015, .02, .03, .04, .06, .08, .1, .15, .2, .3, .4, .6, .8$ $\$ 1.0,1.5,2.0,3.0,4.0,6.0,8.0,10.01$

DATA SBIxD/1.0,.60,.43,.275,.20,.17,.12,.085,.06,.05, 038,.034,

$8.032, .033, .034, .04, .045, .053, .056, .050, .06, .06 /$

DATA DIRLTA/-112.5423, -51.86603, $-22.70358,-10.40648,-4.580516$,

$8-1.203952,-2.603676,-1.131346,-.1063915,-.1830883$,

$8-.06868714,-.02216312, .0003520924, .005751148, .006842417$,

$\$ .01262521, .008856734, .005809170, .001706586, .001042143$,

\$. $0001248412,-.00004150783 /$

DATA CIEITA/7350.127, 4825.127,049.3631,280.3489,293.2492,

$8-124.421,54.43484,10.18168,-.4825736, .7486376, .3053741$,

$8.06886821, .04271434,-.01572356, .02017801,-.008214317$.

$\$ .0006773615,-.003924026, .00002234224,-.0003545637$,

8-.0001040873, .00002091275/

DATA DLELA/-168333.3, -258384.3, -22000.54, 130.0753, -6961.17,

$82080.031,-587.553,-131.0040,8.200074,-1.177545$,

s -1.085026, $-.04525312,-.0073065,05983012,-.01802048$,

$\$ .005027786,-.001534006, .001315756,-.00006281766$,

$\$ .00004174608, .00002083333, .00002083333 /$

c

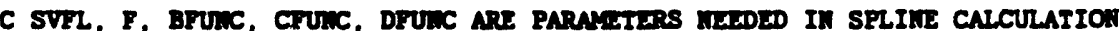
C Or LAURSA's runctial (FUNC) BuLN.

DATA SVTL/-4. \&U517, -3.91202, -3.21887, -2.81341, -2.52573, -2.30258, s $-1.60044,-.91620,-.51083,-.22314,0 \ldots .60315,1.38629,1.79176$,

$82.07044,2.30258,2.09573,3.68888,4.09434,4.38203,4.60517,5.29832$,

s $5.00146,6.30603,6.68461,6.00776 /$

DATA $F / 1.253,1.411,1.580,1.688,1.758,1.702,1.080,2.107,2.398$

\$ 2.565,2.773,3.496,4.867,5.768,6.397,6.867,8.455,0.245,8.904,

$\$ 10.127,10.275,10.545,10.692,10.790,10.878,10.033 /$

DATA DrUIC/.2288849, .2309644, .2140268, .3161113, .2240758, . 1409309,

$\$ .2007453, .4489850, .4939846, .7802218, .9613132,1.469371,2.224274$,

\$ $2.227120,2.006494,2.233934,1.642620,1.487720,1.109183, .6293903$,

$\$ .6281068, .2352380, .2356600, .2782161, .2636840, .2254230 /$

DARA CrULC/-.007068473, .01006856, -.03320577, .2827604, - . 5095552

s .2220258, - .006787031,.2350501,-.1240881,1.150371,-.3701451,

$\$ 1.112114,-.02300823, .03002671,-.4840006,1.100025,-1.053107$,

\& $1.720647,-2.441297, .4607183,-.466067,-.1008493, .1014569$,

$8.005084327,-.05005511,-.1114097 /$

Data DFULC/.008241137, - .02081047, .2597504, -1.022335, 1.228502

$\$-.1104696, .1162986,-.2052353,1.476635,-2.284838, .7171412$

$\$-.5458842, .04359056,-.5057051,2.366401,-1.46824,1.771023$,

$8-3.428081,3.362434,-1.384460, .1756310, .00728069,-.07850358$,

$\$-.07638051,-.0760055,-.0760055 /$

$\mathrm{IN}=12$

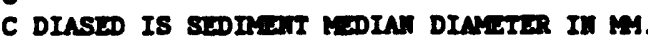

DIA $=$ DIAST

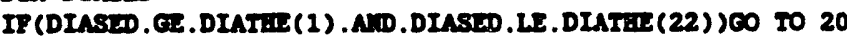

IF (DIASTD.LT.DIAT:E(1) )DIACDIATEL (1)

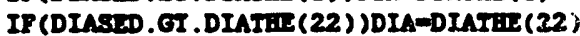

KITI (INR, 10)

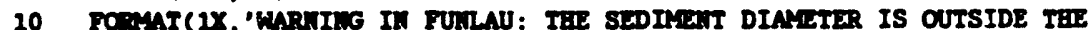

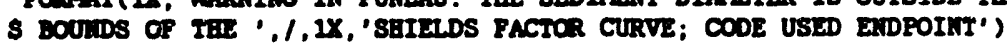

20

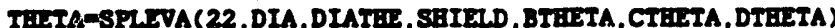

C 
C DIASDM IS SEDIMENT MIDIAN DIANETER IN $M$.

C

c

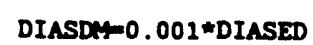

C CONVERT DENSITY OF SEDIMENT (DENSED) AND DENSITY OF WATER

C (DENWAT) FRaY G/OYH*3 TO KG/M**3.

C

DETSED-DENSED 1000.0

c DEINAT=DEHAT $* 1000.0$

C CAICULATE CRITICAL TRACTIVE PORCE POR BEGIMAING OF C SEDIMLAT IRANSFORI.

c

TCRIT-IEETA* (DEASED-DANAT) DIASDY DIADTE-DIASDY/KOEPTE

c C COAPUTE FACTOR (TOPFAC) USED IA BOUMDARY SBIAR EOUATION IN SEDCON. C

c TOFFAC=DENhAT* (DIADTA)**(1./3. )/590.0928

C CALCULATE RATIO OF BEDREST DIALTER TO WATER DEPIE RAISED

C TO TEE $7 / 6$ FONER (TO BE USED IN LAURSEN'S FOFinha BLON).

c

c

RATIO-DIADTE**(7.0/6.0)

C CALCULATE 8Q. ROOT OF BOUTDARY SBEAR (BETAR) USUD If LAURSEN'S c Foritula buow.

c

c

SETAR=SCRT (IDERIE*SLORL*0.80665)

C CALCULATE FUNCTION WADID If LAURSEN'S FOANULA. LOG'S USED FOR ACCURACY.

SELVR-ALOO(SAEAR/SETVA.)

IF (SELVIL.GE.SVIL(1).AND.SEVIL.LE.SVFL(26)) 60 TO 60

IF (SELVT .LT.SVRL (1))SEVEL-SVTL(1)

IF (SEEVI . OT .SVT (26)) SELVILSVIL (26)

WRITL (INP, s0)

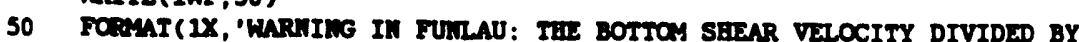

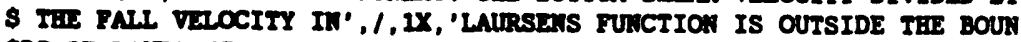

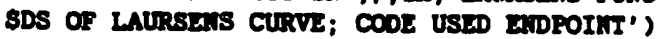

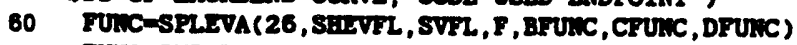

FU,C-IXP(FU,C)

RETUR

END 
SUBROUTINE MATACT (C, AO, P, M, N,DT, A,AI)

PARAMTER (MTEST $=14, M 1=20$ )

$R E A L * B C(M, M), A O(M), P(M), B(M 1, M 1), D(M 1, M 1), \operatorname{MMT1}(M 1, M 1), D T$,

- $\operatorname{TMAT2}(M 1, M 1), A(M), A I(M), C S U M, Q 2, \operatorname{TVEC1}(M 1), \operatorname{TVEC2}(M 1), D U M$, ADDEPS INTEGXR $Q$

CSUIt=0.DO

DO $20 \mathrm{I}=1, \mathrm{H}$

DO $10 \mathrm{~J}=1, \mathrm{~B}$

$C(I, J)=D T * C(I, J)$

DUM $=C(I, J) * C(I, J)$

CSUAYADDEPS (CSUY, DUM)

$10 \quad D(I, J)=0 . D 0$

$20 \quad D(I, I)=1 . D 0$

$Q=2 . D O+(D L O G(D S O R T(C S U N)) / D L O G(2 . D O))$

IF (Q.LT.O.DO) TELA

$Q=0 . D O$

Q2 $=1.00$

ELSE

$Q=Q+1$

$Q 2=1.00 /(2 . D O+\cdots)$

c

$$
\text { EIDIF }
$$

CALL CrROD $(B, Q 2, C, M, N)$

DO 30 K1=1, MTES

K-HIEST+2-K1

ZNLL PRODUC (TMAT1, B, D, $:$ :N)

Q2-1.DO/K

CALL CRRODCD, Q2, TMTI,M, K;

DO $30 I=1,1$

$30 \quad D(I, I)=A D D E P S(D(I, I), 1 . D O)$

CALL CRROD (B, . SDO, B, M, K)

DO $50 \mathrm{~K}=1,0$

CALL CRROD(B, 2.DO,B, M, M)

CAIL EROOUC(TMT1,B,D,M, M)

CALL CPBOD(TMAT1, .SDO, TMAT1, M, R)

DO $40 \quad I=1,1$

$40 \operatorname{MMT1}(I, I)$-ADDEPS $(\operatorname{MMT} 1(I, I), 1 . D 0)$

CNLL FRODUC (TMAT2, D, DMTI, $M, H$ )

DO $50 I=1,1$

DO $50 \mathrm{~J}=1, \mathrm{n}$

c

$D(I, J)=\operatorname{mat} 2(I, J)$

CALL PRODUC (TMAT2, C, D,M, M)

DO $60 \quad I=1, \pi$

$60 \operatorname{MAT2}(I, I)=A D D E P S(\operatorname{MAT2}(I, I), 1 . D O)$

CALL. VERDUC (AI, TMAT2,AO,M,M)

CAIL VERDUC (IVECI, D, P,M, M)

CNLL CVRD (TVEC1, DT, TVEC1,M, R)

DO $70 \mathrm{I}=1, \mathrm{~A}$

$70 \quad A(I)=A D D E P S(A I(I), \operatorname{TVECI}(I)$

C DO 80 I-1,H

$80 \operatorname{TMATI}(I, I)$-ADDEPS(D(I,I),-1.DO)

CALL VRPDUC (TVDC1, TMII, $P, M, H$ )

CALl VRRDUC (TVEC2, C, IVEC1, M, M)

CALL VRRDUC (IVEC1,D,AO,M, $\mathrm{N}$ )

CALL CVRRD (TVEC1, DT, TVEC1,M, K)

DO $90 I=1,1$

$90 A I(I)=A D D E P S(A I(I), \operatorname{ADDEPS}(\operatorname{IVEC}(I), \operatorname{IVEC} 1(I))$ )

RETURY

Ind 


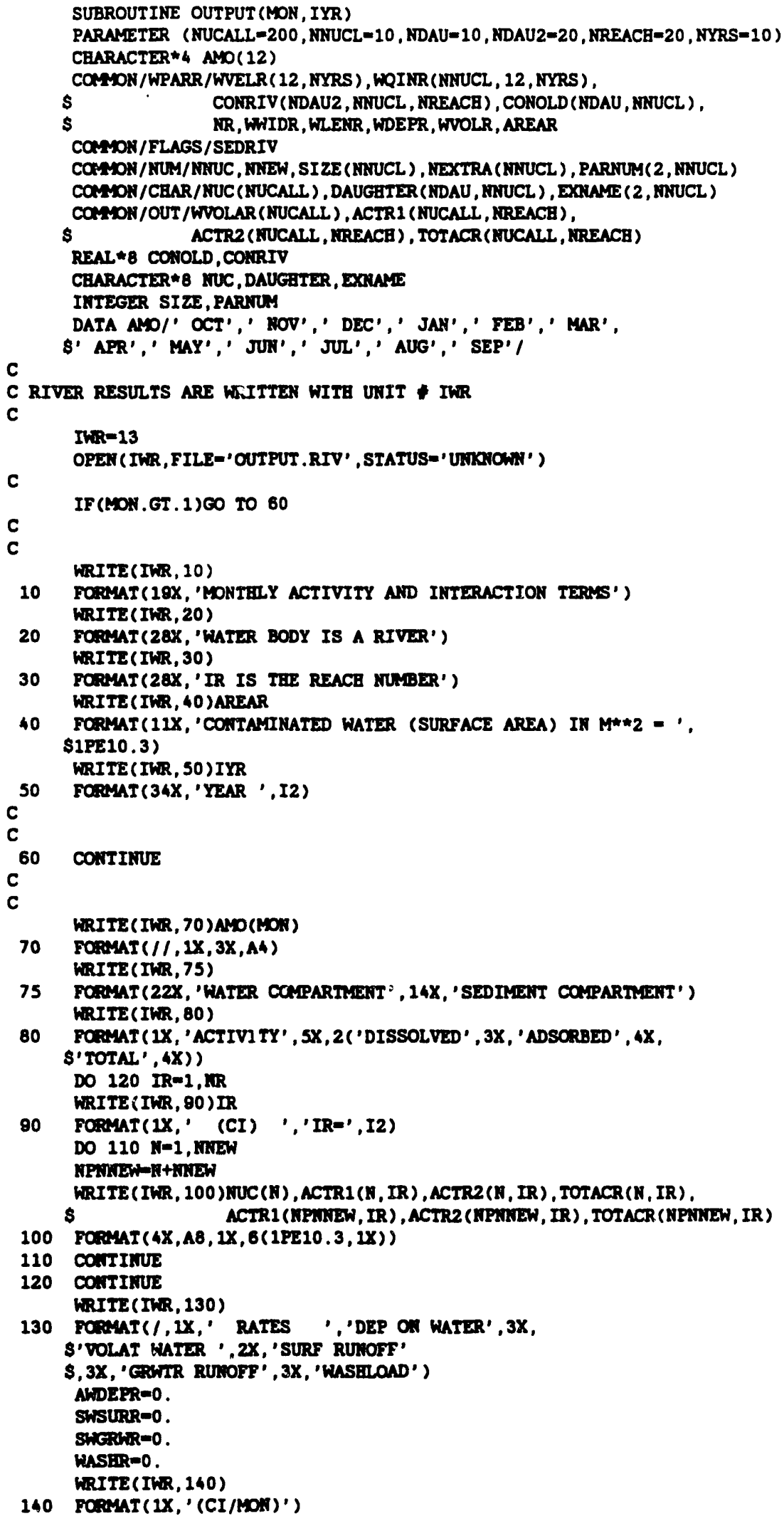




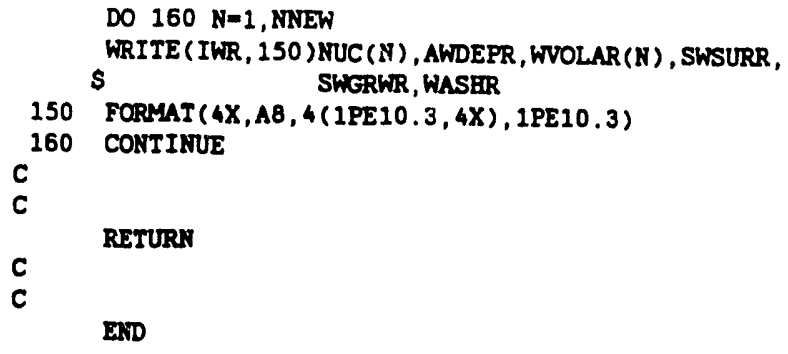




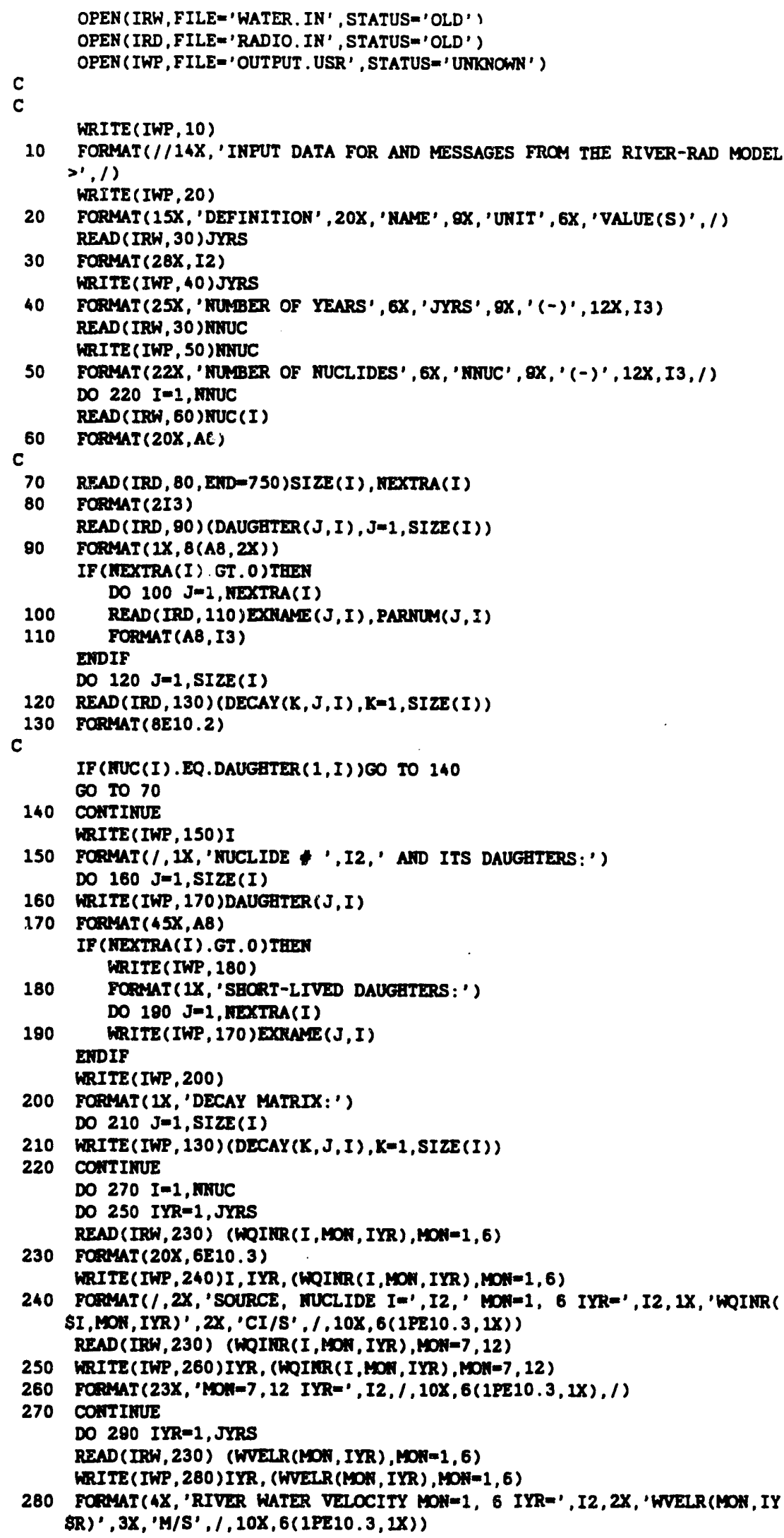


READ (IRW, 230) (WVELR (MON, IYR), MON=7, 12)

290 WRITE (IWP, 260) IYR, (WVELR (MON, IYR), MON=7, 12)

READ (IRW, 30) IR

WRITE(IWP, 300) $\mathrm{KR}$

300 FORMAT (23X, 'NUMBER OF REACEES', 7X, 'KR', 10X,'(-)', 12X, I3)

READ (IRN, 230) WLEKR, WWIDR, WDEPR

WRITE (IWP, 310)WLERR

310 FORAMT (18X, 'LENGTE OF RIVER REACB', 6X, 'WLEKR', 8X, 'M', 6X, 1PE10, 3) WRITE (IWR, 320 )WWIDR

320 POPMAT (20X, 'WIDTE OF RIVER REACE' , 6X, 'WWIDR', 8X, 'M' , 6X, 1PE10, 3) WRITE (IWR, 330)WDEFR

330 FOAMT (20X, 'DEPTE OF RIVER REACE' ,6X, 'WDEPR', OX, 'M', 6X, 1PE10.3, /) WVOLR WLFTR WWIDR WDEFR

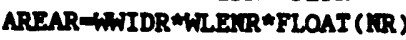

DO $420 \quad I=1$, ErTUC

DO $420 \mathrm{~J}=1, \mathrm{SIZE}(\mathrm{I})$

$\operatorname{READ}(\operatorname{IRN}, 230) \operatorname{WKVR}(J, I), \operatorname{SNTDR}(J, I)$

C WRITE VOLATILIZATIOA AND KO ONY OACE FOR EACA RADIONUCLIDE (I.E.,

C IF TWO PARETTS BAVE TEE SAME DAUCATERS, WRITE TEE IBFOPAMTIOA OACE).

IF(I.20.1) 100 To 360

IMI $=I-1$

DO 350 L=1, IM1

DO $340 x=1, \operatorname{sIZE}(L)$

LLEL

$\mathbf{L K}-\mathbf{K}$

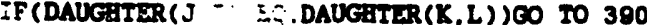

$34 \mathrm{C}$ - כNTINUE

350 CONTIRUE

360 ConrInUe

MRITE (IWR , 370) DAUGETER (J, I), $\operatorname{WKVR}(J, I)$

370 ropeat (8X, ' VOLATILIZATIOA RATE FOR ', $18,6 X$, 'WKVR', 8X, 'S*t-1', 4X, S1PE10 :

KRIIE (IWR, 380) DAUGETER (J, I), SWKDR (J, I)

380 FOCEAT (5X, 'DISTRIBUTION COSFF. 100 FOR ',A8, 6X, 'SWCDR'

$8,4 X$, 'ATI/G/ATY/EL', 2PE10.3)

CO TO 420

390 CONTIMUE

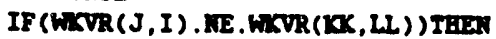

ReITE (IWP, 400)I, J, LL, RK

400 FORAMT (/,1X, 'ERROR - VOL ". IIZATIOA FOR RUCLIDE ', I2,' DAUGETER '. $>$ I2,' SBOULD BE BUT IS WOT TEE', $1,1 \times$, 'SNE AS FOR RUCLIDE ',I2,' DA >UGATER ',I2)

STOP

ETDIF

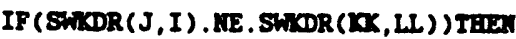

KeITE(IWR, 410)I, J, Ll, WK

410 FOPAMT (/, IX,' ERROR - WD FOR MUCLIDE ', I2,' DAUGATER ', I2,' SBOULD $>B E$ BUT IS MOT THE SAVE AS POR', $1,1 \times$, 'MUCLIDE ',I2,' DAUGETER ', I2) STOP

MTIF

420 Contrine

C

430 POaAnt $(26 x, A 4)$

READ (IRE, 430)SERRTV

REITE (IWP, 440)

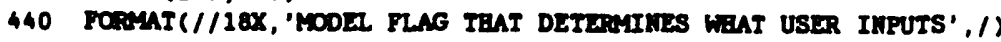

KRITE (IWP, 450)

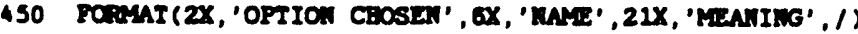

c

IF (SEDRIV. EO. YES.0R.STERTV.20.10) 100 TO 470

WRITE (IWT, 460) SIDRIV

460 POPMAT (2X,' ERROR IA DATA: SEDRIV DOES NOT EOUAL YES OR MO, BUT - '

s. A4)

STOP

470 contrinus 
IF(SEDRIV.EQ.NO)GO TO 500

WRITE (IWP, 480)

480 FORMAT (12X, 'YES', 5X, 'SEDRIV', 5X, 'SIGNIFIES THAT SEDIMENT CONCENTRA STIONS FOR THE')

WRIIE(IWP, 490)

490 FORMAT (32X, 'RIVER ARE INPUT (SEE BELON)',/) GO TO 530

500 WRITE(IWR, 510)

510 FORMA (13X, 'RO', 5X, 'SEDRIV', 5X, 'SIGIFIES TBAT SEDIMENT PARAMETERS S (FOR LAURSEHS')

WRITE(IWP, 520)

520 FORAMT (32X, 'FORAULA) FOR TEE RIVER ARE INPUT (SEE BELON)', /)

530 CONTINUE

IF (SEDRIV. DO.YES) 60 TO 530

READ(IRW, 230)DENSDR, DENKR, SLOPER

WRITE( IWP, 550)DENSDR

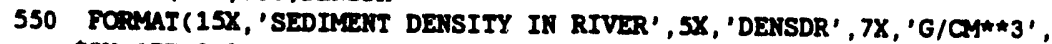
S2X, 1PE10.3)

WRITE(IWP, 560)DEATR

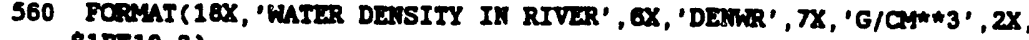
\$1F210.3)

KRITE(IWP, 570) SLOPER

570 FCAMAT (26X, 'SLOPE OF RTVER', 5X, 'SLOPER', 8X, '(-)', 5X, 1PE10.3)

Co 10610

580 DO 600 IYR=1, JYRS

READ (IRH, 230) (SEDCR (MON, IYR), MON=1, 6)

KRITE (IWP, 590) IYR, (SEDCR (MOR, IYR), MON=1, 6)

590 FORMA (2X, 'SEDIFENI CONC. (RIVER) MON=1, 6 IYR=', I2, 2X, S'SEDCR (MON, IYR)' , 2X, 'KG/MH+3' , /, 20X, 6(1PE10,3,1X))

$\operatorname{READ}(\mathrm{IBN}, 230$ ) (SEDCR (MON, IYR), MON=7, 12)

600 KRITE (IWP, 260) IYR, (SEDCR ( $M O N$, IYR), MON=7, 12)

610 CONTINUE

READ (IRW, 230)DIASDR , SEDCS , SDEFR, RESVEL, SEDVEL, SETVEL WRIIE(IWP, 611)DIASDR

611 FOAMT (7X, 'MLDIAN SEDINIAT DIAYETER IN RIVER' ,5X, 'DIASDR', 9X, 'MY', \$5X, 1PE10.3)

KRITE(IKP, 612)SEDCS

612 FORAT (2X, 'SOLIDS CONCEMTRATIOA IH SEDINENT LAXER', 6X, 'SEDCS', 7X, S'KG/Matis' , 2X, IFE10.3)

KRITE(IWP, 613)SDEPR

613 FORMA (17X, 'DEFTH OR STDIMLAT LAYAR' , 6X, 'SDEPR' , 10X, 'M', 5X, \$1FE10.3)

IF (SETVEL. RE.0.) 60 TO 614

c

C CALL VFALL HIRE TO COYPUTE THE SETTLING VELOCITY OF SEDIMENT PARTICLES C IN TBE STREAM (KRITE OUT TEI RESULTS - SEIVEL)

CALL VFALL(DIASDR)

614 WRITE(IWP, 615)SETVR

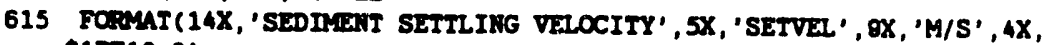
\$1PE10.3)

KRITL(IWP, 617)RESVA

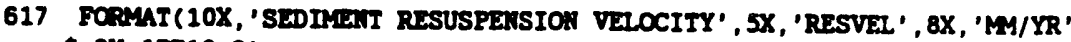
$\$, 3 X, 1 P E 10.3)$

WRITE(IWP, 619)SIDVET

619 FOPA4T(18X, 'SWDIENTATIOA VEOCITY', 5X, 'SEDVR', 8X, 'MY/YR' , 3X, \$1PL10.3)

C CONVERT RESVEL \& SEDVEL TO M/S (FROY MY/YR)

RESVEL-RESVEL / 3 . 1536E10

SEDVER-SEDVR/3.1536E10

C

KRITE(TWG, 620)

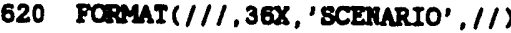

DO $630 I=1$, NRuC

DO 630 IYR=1, JYRS

DO 630 MON=1, 12 
630 IF (WQINR (I, MON, IYR). NE. 0.0)GO TO 650

WRITE (IWG, 640)

640 FORMAT ( $1 X, 31 X$, 'RIVER (NO SOURCE)' )

CO TO 670

650 IRIV $=1$

WRITE (IWG, 660)

660 FORMAT (1X,31X, 'RIVER (BAS SOURCE)')

670 Cont InUE

c

KRITE (ING, 680)

680 FORMT $(/ /, 29 x$, 'MANITUDE OF SOURCE(S)', /)

WRITE (IWG, 690) (AMO (I), I=1, 12)

690 Fapant $(1 X, 6 X, 6(6 X, 14), /, 7 X, 6(6 X, 14), /)$

IF (IRIV.NE. 1)RETURH

WRITE (IWG, 700)

700 FOaMAT(/, IX, 'RIVER')

WRITE (IWG, 710)

710 Foparat (1X.' (CI/SEC)')

DO $730 I=1$, MUUC

WRITE (ING, 720)I

720 FOPAMT ( $1 \times$, 'MUCLIDE, I2)

DO 730 IYR=1, JRRS

730 WRITE (IWG, 740)IYR, (WOIKR (I, MON, IYR), MON=1, 12)

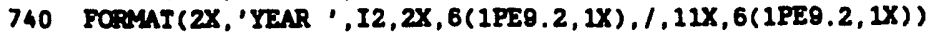
REIURR

750 WRITE (IWR, 760$)$ RUC (I)

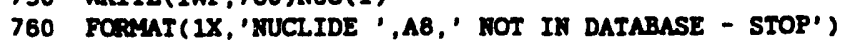
STOP

END 


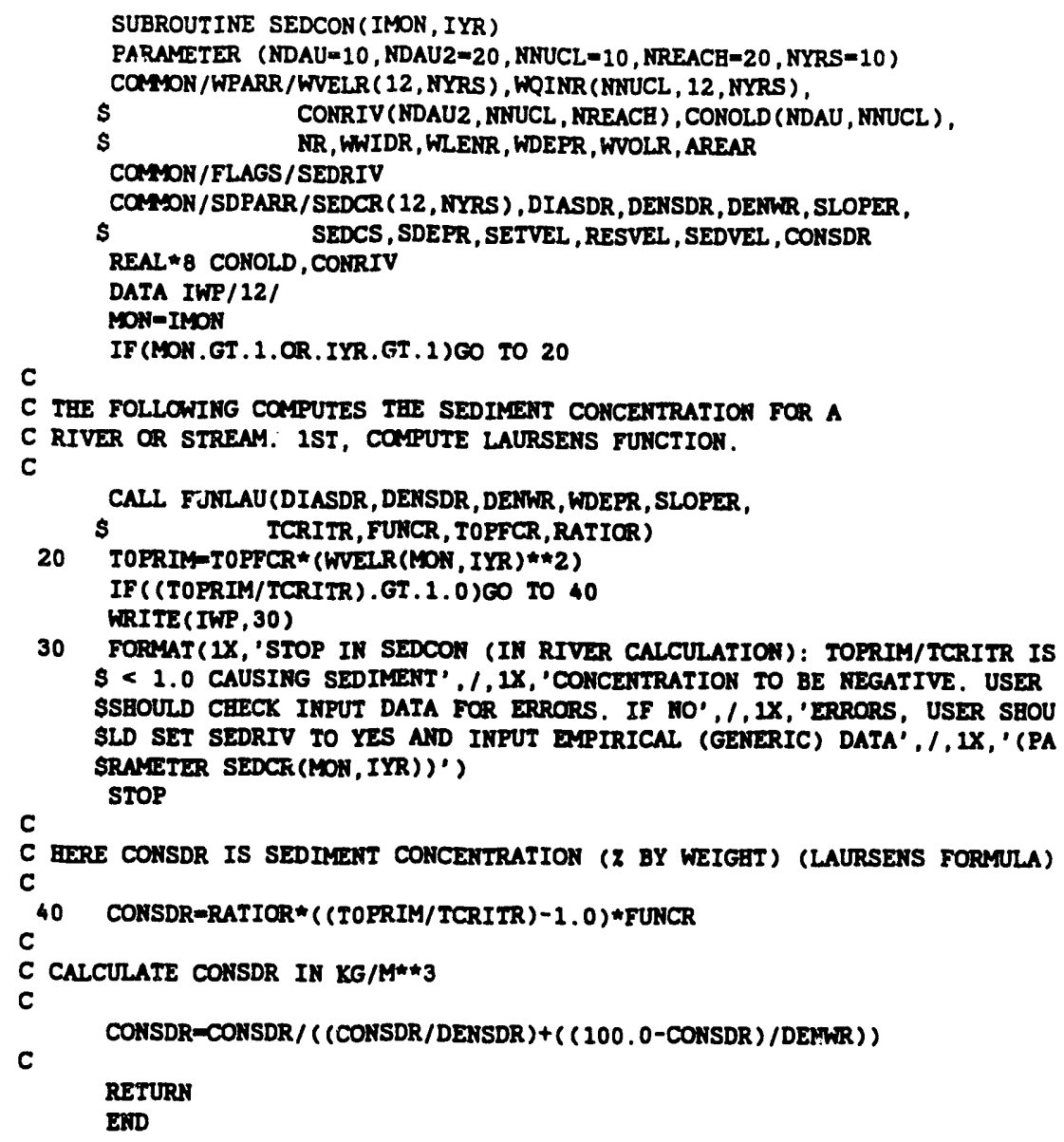




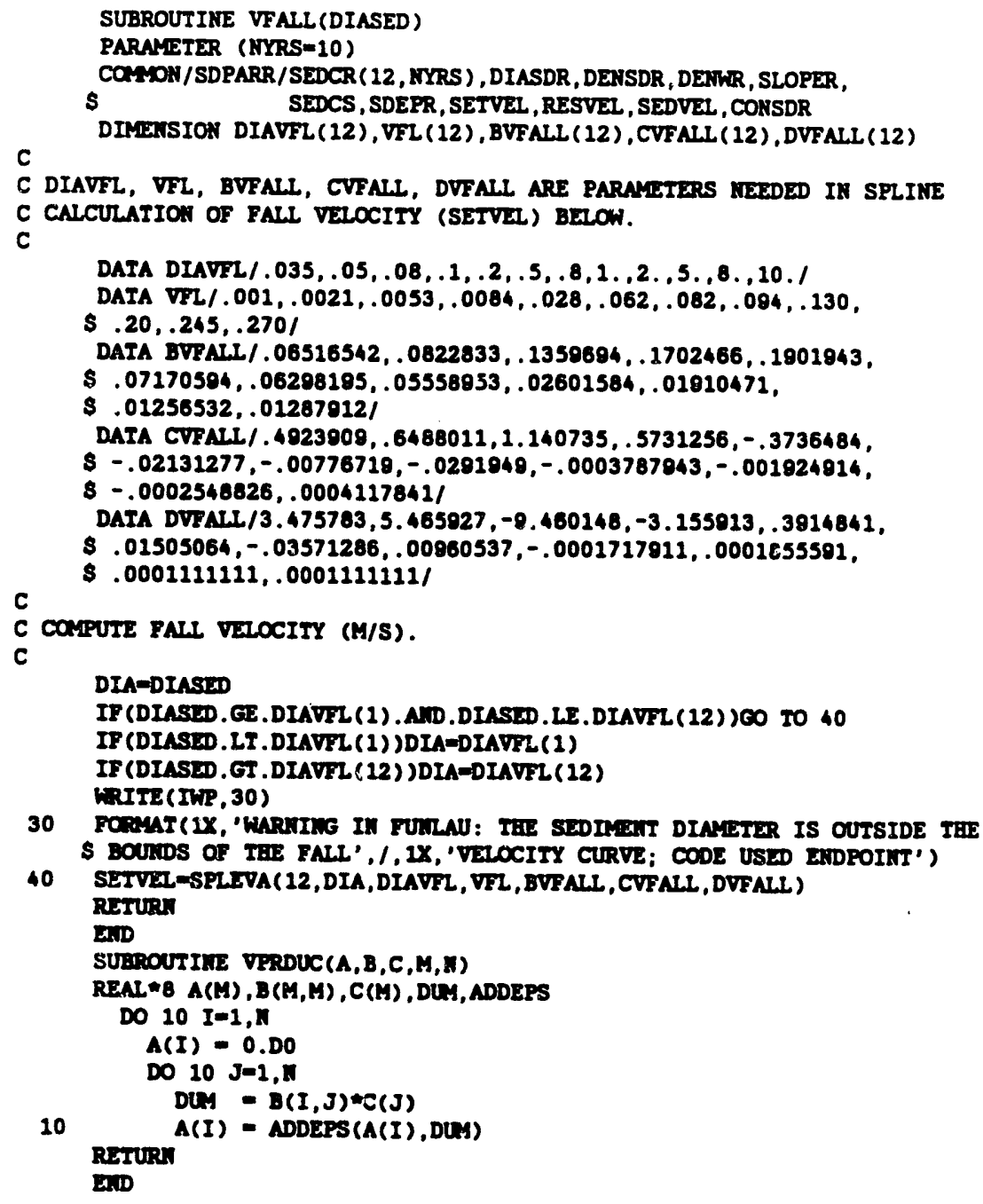




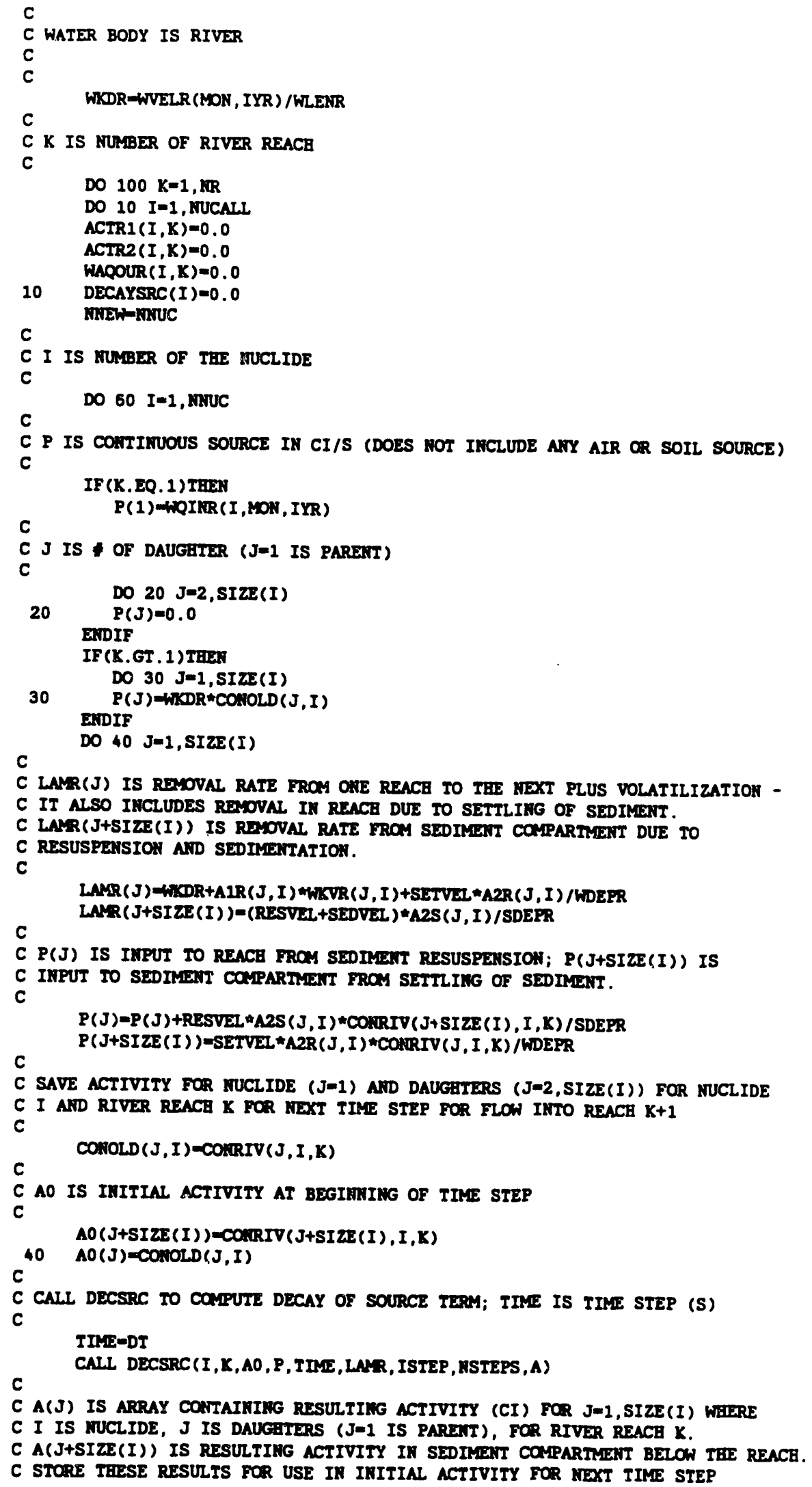


C (SEE AO ABOVE) AND FOR FLOW FROM REACB TO REACB (SEE CONOLD ABOVE).

C

DO $50 \mathrm{~J}=1, \operatorname{SIZE}(I)$

$\operatorname{COKRIV}(J+\operatorname{SIZE}(I), I, K)=A(J+\operatorname{SIZE}(I))$

so $\operatorname{CORRIV}(J, I, K)=A(J)$

60 CONTINUE

C COMPUTE TOTAL MOATHLY VOLATILIZATIOH

C

IF(ISTEP.GT.1.OR.K.GT.1) 100 TO 80

DO $70 \quad k=1$, RIEN

WVOLAR(A) $=0.0$

DO $90 \mathrm{~N}=1$, REN

WOLAR $(A)=$ WOLLAR $(K)+$ WAPOUR $(M, K) \backsim D T$

C

100 Comrinus

c

REIUR

EID 


\section{APPENDDX B}

\section{IMPN口TANT PARAMETERS AND THEIR DEFINITIONS}

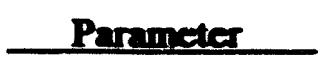

$\mathbf{A}(\mathbf{J})$

A(J+SIZE(I))

AO(J)

AO(J+SIZE(I))

$\operatorname{A1R}(\mathrm{J}, \mathrm{J})$

A2R(J,I)

$\operatorname{A1S}(\mathrm{J}, \mathbf{I})$

A2S(J,I)

\section{Definition}

Resulting activity (Ci) of radionuclide $J$ in a decay chain in a river reach (water compartment) that is computed at end of $y$ time step

Same as $A(J)$ only for the sodiment compartment

Initial activity $(\mathrm{Ci})$ of radionuclide $\mathrm{J}$ in a decay chain in a river reach (water compartment) at the beginning of a time step

Same as $A O(J)$ only for the sediment compartment

Fraction of daughter $\mathrm{J}$ ( $J=1$ is parent) of radionuclide chain I that is in dissolved phase in water compartment

Fraction of daughter $\mathbf{J}$ ( $J=1$ is parent) of radionuclide chain I that is in adsorbed phase in water compartment

Same as A1R(J,I) only for the sediment compartment

Same as A2R(J,I) only for the sediment compartment
Jocation

SUBROUTINES WATER, DECSRC, and MATACT

SUBROUTINES WATER, DECSRC, and MATACT

SUBROUTINES W/ATER, DECSRC, and MATACT

SUBROUTINES WATER, DECSRC, and MLATACI

CC.MMON/ALPHAS/

COMMON/ALPHAS/

COMMON/ALPHAS/

COMMON/ALPHAS/ 
Parameter

ACTOUT(MM)

ACTR1(N,IR)

ACTR1(N+NNEW,I,

ACTR2(N,IR)

ACTK2

$(\mathrm{N}+\mathrm{NNEW}, \mathrm{IR})$

AREA $R$

AWQINR

BFUNC

BTHETA

BVFALL
Definition

An array that keeps track of which members of each radionuclide chain are the same (the results for members are added together)

Dissolved activity (Ci) of radionuclide $\mathbf{N}$ in reach IR in the water compartment

Same as ACTR1(N,IR) only in the sediment compartment

Adsorbed activity (Ci) of radionuclide $\mathbf{N}$ in reach IR in the water compartment

Same as ACTR2(N,IR) only in the sediment compartment

The surface area of the river in $\mathbf{m}^{2}$

Air-to-water deposition rute (assumed to be 0.0 )

Array used to store cubic coefficients $b_{i}$ (Forsythe et al., 1977) needed in spline fit of Laursen's function (Laursen, 1958)

Array used to store cubic coefficients $b_{i}$ (Forsythe et al., 1977) needed in spline fit of Shields factor (Bagnold, 1966)

Array used to store cubic coefficients $b_{i}$ (Forsythe et al., 1977) needed in spline fit of the fall velocity (Fields, 1976)
Location

SUBROUTINE DECSRC

COMMON/OUT/

COMMON/OUT/

COMMON/OUT/

COMMON/OUT/

COMMON/WPARR'

COMMON/MEDIA

SUBROUTINE FUNLAU

SUBROUTINE FUNLAU

SUBROUTINE VFALL 


\begin{tabular}{|c|c|c|}
\hline Parameter & Definition & Location \\
\hline $\mathrm{C}(\mathrm{MM}, \mathrm{MM})$ & Radiological decay matrix & $\begin{array}{l}\text { SUBROUTINES DECSRC } \\
\text { and MATACT }\end{array}$ \\
\hline CFUNC & $\begin{array}{l}\text { Array used to store cubic } \\
\text { coefficients } c_{i} \text { (Forsythe } \\
\text { et al., 1977) needed in } \\
\text { spline fit of Laursen's } \\
\text { function (Laursen, 1958) }\end{array}$ & SUBROUTINE FUNLAU \\
\hline CONOLD(J,I) & $\begin{array}{l}\text { Activity in } \mathrm{Ci} \text { for } \\
\text { daughter } \mathrm{J}(\mathrm{J}=1 \text { is parent) } \\
\text { of nuclide chain I that is } \\
\text { saved for the next time } \\
\text { step in computing flow } \\
\text { from one reach to the next }\end{array}$ & COMMON/WPARR/ \\
\hline CONRIV(J,I,K) & $\begin{array}{l}\text { Activity in } \mathrm{Ci} \text { for } \\
\text { daughter } \mathrm{J}(\mathrm{J}=1 \text { is parent) } \\
\text { of nuclide chain I in river } \\
\text { reach } \mathrm{K} \text { (water compartment) }\end{array}$ & COMMON/WPARR/ \\
\hline $\begin{array}{l}\operatorname{CONRIV}(\mathrm{J}+\operatorname{SIZE}(\mathrm{I}) \\
\mathrm{I}, \mathrm{K})\end{array}$ & $\begin{array}{l}\text { Same as CONRIV }(\mathrm{J}, \mathrm{I}, \mathrm{K}) \text { only } \\
\text { for the sediment compartment }\end{array}$ & COMMON/WPARR/ \\
\hline CONSDR & $\begin{array}{l}\text { The average suspended } \\
\text { sediment concentration in } \\
\mathrm{kg} / \mathrm{m}^{3} \text { for the river }\end{array}$ & COMMON/SDPARR/ \\
\hline CTHETA & $\begin{array}{l}\text { Array used to store cubic } \\
\text { coefficients } c_{i} \text { (Forsythe } \\
\text { et al., 1977) needed in } \\
\text { spline fit of Shields } \\
\text { factor (Bagnold, 1966) }\end{array}$ & SUBROUTINE FUNLAU \\
\hline CVFALL & $\begin{array}{l}\text { Array used to store cubic } \\
\text { coefficients } c_{i} \text { (Forsythe } \\
\text { et al., 1977) needed in } \\
\text { spline fit of the fall } \\
\text { velocity (Fields, 1976) }\end{array}$ & SUBROUTINE VFALL \\
\hline DAUGHTER(J,I) & $\begin{array}{l}\text { The names of the parents } \\
\text { and their daughters. } I \text { is } \\
\text { index for the chain, } J=1 \text { is } \\
\text { index for the parent, and } \\
J=2, \text { SIZE(I) are indices for } \\
\text { the daughters }\end{array}$ & COMMON/CHAR/ \\
\hline
\end{tabular}


Parameter

$\operatorname{DECAY}(\mathrm{K}, \mathrm{J}, \mathbf{I})$

DECAYSRC(N)
Definition

Decay matrix for chain I;

$\mathrm{K}$ and $\mathrm{J}$ are indices for length of the chain

Total resulting activity (Ci) for nuclide $\mathrm{N}$ in the water compartment, where $\mathrm{N}=1, \mathrm{NNEW}$

DECAYSRC(N+NNEW)

Same as DECAYSRC $(N)$ only for the sediment compartment

DENSDR

DENWR

DFUNC

DIASDR

DIATHE

DIAVFL

DT
The sediment density in

The density of the water in the river in $\mathrm{g} / \mathrm{cm}^{3}$

Array used to store cubic coefficients $d_{i}$ (Forsythe et al., 1977) needed in spline fit of Laursen's function (Laursen, 1958)

The median sediment diameter in the river bed in $\mathbf{m m}$

Array containing values of median sediment diameter in $\mathrm{mm}$ that were used in the spline fit to the Shields factor curve (Bagnold, 1966); see parameter SHIELD below

Array containing values of median sediment diameter in $\mathrm{mm}$ that were used in the spline fit to the fall velocity curve (Fields, 1976); see parameter VFL below

Duration of time step in s the river in $\mathrm{g} / \mathrm{cm}^{3}$
Location

COMMON/DEC/

COMMON/DEC/

COMMON/DEC/

COMMON/SDPARR/

COMMON/SDPARR/

SUBROUTINE FUNLAU

COMMON/SDPARR/

SUBROUTINE FUNLAU

SUBROUTINE VFALL

SUBROUTINES EXEC, WATER, and MATACT 


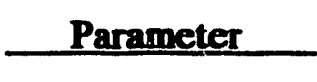

DTHETA

DVFALL

EXNAME(J,I)

$\mathbf{F}$

FUNC

FUNCR

GRWROF

IMO or IMON

IR
Array used to store cubic coefficients $d_{i}$ (Forsythe et al., 1977) needed in spline fit of Shields factor (Bagnold, 1966)

Array used to store cubic coefficients $d_{i}$ (Forsythe et al., 1977) needed in spline fit of the fall velocity

(Fields, 1976)

The names of short-lived daughters for chain I. $J=1, N E X T R A(I)$, where NEXTRA(I) is the number of short-lived daughters for chain I

Array used to store values of Laursen's function taken from Laursen's curve (Laursen, 1958) at points SVFL (see below); this array contains the natural $\log$ of the actual points from the curve in order to increase accuracy

Function needed in Laursen's formula (Laursen, 1958)

Same as FUNC

Radionuclides in groundwater runoff to river in $\mathrm{Ci} / \mathrm{s}$ (assumed to be 0.0 )

Index signifying month of the year; 1 = October

Number of the current reach in the river
Location

SUBROUTINE FUNLAU

SUBROUTINE VFALL

COMMON/CHAR/

SUBROUTINE FUNLAU

SUBROUTINE FUNLAU

SUBROUTINE SEDCON

COMMON/MEDIA

Numerous subroutines

SUBROUTINE OUTPUT 
IRD

Logical input device number used for reading radiological decay matrices from file RADIO.IN

IRW

Logical input device number used for reading water parameters from file WATER.IN

ISTEP

The index of the current time step within the current month

SUBROUTINE READIN

SUBROUTINE READIN

Logical output device number used for writing a table of the radionuclide sources in file OUTPUT.USR

IWP

Logical output device number used for writing the input data and other messages (such as warnings or errors) in file OUTPUT.USR

IYR

The index of the current year

Numerous Subroutines

JYRS

The number of years to be simulated (input)

SUBROUTINES DECSRC, EXEC, and WATER

SUBROUTINE READIN

SUBROUTINE READIN

Removal rate from one reach to the next plus volatilization for radionuclide $\mathrm{J}$

COMMON/EXI

LAMR(J)

LAMR(J +SIZE(I))

Removal rate from sediment compartment due to resuspension and sedimentation

SUBROUTINES WATER and DECSRC

SUBROUTINES_WATER DECSRC

Numerous subroutines

Index signifying month of the year; 1 = October

NDAU

The number of members allowed in a radionuclide chain (set to 10)

PARAMETER statement in several subroutines 
Parameter

NDAU2

NEXTRA(I)

NNEW

NNUC

NNUCL

NR

NREACH

NSTEPS

NUC(I)

NUCALL

NYRS

$\mathbf{P}(\mathrm{J})$
Twice the number of members allowed in a radionuclide chain (set to 20)

The number of short-lived daughters for chain I

The total number of source nuclides plus daughters

The number of source radionuclides to be simulated (input by the user)

The number of parent nuclides allowed in a simulation (set to 10)

The number of reaches that the river is broken into (input)

The number of river reaches allowed (set to 20)

The number of time steps taken each month (currently is set to 30)

The radionuclide name of parent nuclide I input by the user

Twice ine total number of parent (source) nuclides plus daughters (set to 200)

The number of years allowed in the simulation (set to 10)

Source in Ci/s for radionuclide $\mathrm{J}$ in water compartment; $\mathrm{J}=1$ is parent and $\mathrm{J}=2, \operatorname{SIZE}(\mathrm{I})$ are daughters
Location

PARAMETER statement in several subroutines

COMMON/NUM/

COMMON/NUM/

COMMON/NUM/

PARAMETER statement in some subroutines

COMMON/WPARR/

PARAMETER statement in some subroutines

SUBROUTINES DECSRC, EXEC, and WATER

COMMON/CHAR/

PARAMETER statement in some subroutines

PARAMETER statement in some subroutines

SUBROUTINES WATER, DECSRC, and MATACT 


\begin{tabular}{|c|c|c|}
\hline Parameter & Definition & Location \\
\hline $\mathrm{P}(\mathrm{J}+\mathrm{SIZE}(\mathrm{I}))$ & $\begin{array}{l}\text { Source in } \mathrm{Ci} / \mathrm{s} \text { for } \\
\text { radionuclide } \mathrm{J} \text { to sediment } \\
\text { due to settling of sediment } \\
\text { from the water compartment; } \\
\mathrm{J}=1 \text { is parent and } \mathrm{J}=2 \text {, } \\
\text { SIZE(I) are daughters }\end{array}$ & $\begin{array}{l}\text { SUBROUTINES WATER } \\
\text { DECSRC, and MATACT }\end{array}$ \\
\hline PARNUM(J,I) & $\begin{array}{l}\text { The index of the parent } \\
\text { for the short-lived } \\
\text { daughter EXNAME(J,l) for } \\
\text { index } J \text { in chain } I \text { in } \\
\text { array DAUGHTER }\end{array}$ & COMMON/NUM/ \\
\hline RATIO & $\begin{array}{l}\text { Parameter needed in } \\
\text { Laursen's formula to compute } \\
\text { sediment concentration; } \\
\text { RATIO is the ratio of the } \\
\text { sediment diameter to water } \\
\text { depth raised to the } 7 / 6 \text { power }\end{array}$ & SUBROUTINE FUNLAU \\
\hline RESVEL & $\begin{array}{l}\text { Sediment resuspension } \\
\text { velocity (input as } \mathrm{mm} / \mathrm{y} \text { ear } \\
\text { and converted to } \mathrm{m} / \mathrm{s} \text { ) }\end{array}$ & COMMON/SDPARR/ \\
\hline SDEPR & $\begin{array}{l}\text { The depth of the sediment } \\
\text { layer }(\mathrm{m})\end{array}$ & COMMON/SDPARR/ \\
\hline SEDCR(MON,IYR) & $\begin{array}{l}\text { The average suspended } \\
\text { sediment concentration } \\
\text { in the river for month MON } \\
\text { and year } \Gamma \mathrm{YR}\left(\mathrm{kg} / \mathrm{m}^{3}\right)\end{array}$ & COMMON/SDPARR/ \\
\hline SEDCS & $\begin{array}{l}\text { The solids concentration in } \\
\text { sediment layer }\left(\mathrm{kg} / \mathrm{m}^{3}\right)\end{array}$ & COMMON/SDPARR/ \\
\hline SEDRIV & $\begin{array}{l}\text { SEDRIV is a flag; if YES } \\
\text { the suspended sediment } \\
\text { concentration in the river } \\
\text { is known, if NO it is not }\end{array}$ & COMMON/FLAGS/ \\
\hline SEDVEL & $\begin{array}{l}\text { The sedimentation velocity } \\
\text { or rate of burial (input as } \\
\text { mm/year and converted to } \mathrm{m} / \mathrm{s} \text { ) }\end{array}$ & COMMON/SDPARR/ \\
\hline
\end{tabular}


Parameter

SETVEL

SHEAR

SHIELD

SIZE(I)

SLOPER

SURROF

SVFL

SWKDR(J,I)
The sediment settling velocity in $\mathrm{m} / \mathrm{s}$. User can input SETVEL or the code will compute it (subroutine VFALL)

Used in Laursen's formula for sediment concentration, SHEAR is the square root of the boundary shear

Array containing values of Shield's factor at sediment diameters DIATHE (see above) from the curve given in Bagnold (1966)

The length of the radionuclide chain I; the parent plus the number of daughters

The slope of the river bed

Radionuclides in surface runoff to river in $\mathrm{Ci} / \mathrm{s}$ (assumed to be 0.0 )

Array used to store values of $\sqrt{\tau_{0} / \rho} / w_{a}$ from Laursen's curve (Laursen, 1958); this array contains the natural log of the actual points from the curve in order to increase accuracy (see parameter $F$ above)

Soil-water distribution coefficient in (atoms/g)/ (atoms $/ \mathrm{mL}$ ) for daughter $\mathrm{J}$ ( $\mathrm{J}=1$ is parent) of radionuclide chain I
Location

COMMON/SDPARR/

SUBROUTINE FUNLAU

SUBROUTINE FUNLAU

COMMON/NUM/

COMMON/SDPARR/

COMMON/MEDIA

SUBROUTINE FUNLAU

COMMON/EQUIL 
SWQINR

Surface runoff plus groundwater runoff in $\mathrm{Ci} / \mathrm{s}$

COMMON/MEDIA/ into the river at beginning of time step (assumed to be 0.0)

SWQOUR

Surface runoff plus groundwater runoff in $\mathrm{Ci} / \mathrm{s}$ into the river at end of time step (assumed to be 0.0 )

TCRIT

Critical tractive force for beginning of sediment transport in $\mathrm{kg} / \mathrm{m}^{2}$

TCRITR

Same as TCRIT

SUBROUTINE SEDCON

THETA

Shields factor used in calculation of TCRIT

SUBROUTINE FUNLAU

(Laursen, 1958 and

Bagnold, 1966)

TIME

Time step in s

SUBROUTINES WATER and DECSRC

TOPRIM

Boundary shear $\tau_{0}{ }^{\prime}$ associated with sediment particles in $\mathrm{kg} / \mathrm{m}^{2}$

TOTACR(N,IR)

Total activity ( $\mathrm{Ci}$ ) for radionuclide $\mathrm{N}$ in reach IR (water compartment)

COMMON/MEDIA

SUBROUTINE FUNLAU

SUBROUTINE SEDCON

COMMON/OUT/

TOTACR(N+NNEW,IR) Same as TOTACR(N,IR) only for the sediment compartment

VFL

Array containing sediment fall velocity values in $\mathrm{m} / \mathrm{s}$ taken from velocity curve given in Fields, 1976 (see parameter DIAVFL above)

WAQOUR(N,K)

Volatilization rate $(\mathrm{Ci} / \mathrm{s})$ for nuclide $\mathbf{N}$ from reach $K$

COMMON/OUT/

SUBROUTINE VFALL

COMMON/MEDIA 
Parameter

WDEPR

WKDR

WKVR(J,I)

WLENR

WQINR(I,MON,IYR)

WVELR(MON,IYR)

WVOLAR(N)

WVOLR

WWIDR
The average depth of the river in $\mathrm{m}$

Rate at which water flows out of the river in $\mathrm{s}^{-1}$

The volatilization rate constant in $\mathrm{s}^{-1}$ for daughter $\mathrm{J}(\mathrm{J}=1$ is parent) of radionuclide chain I

The length of each river reach in $m$ (all reaches have the same length)

Radionuclide source rate into reach 1 of the river for parent I, month MON, and year IYR in $\mathrm{Ci} / \mathrm{s}$

Current velocity of the river for month MON and year IYR in $\mathrm{m} / \mathrm{s}$

Total monthly volatilization from river

The water volume of each reach in $\mathrm{m}^{3}$

The average width of the river in $m$ that is input by the user
Location

COMMON/WPARR/

SUBROUTINE WATER

COMMON/WRATES/

COMMON/WPARR/

COMMON/WPARR/

COMMON/WPARR/

COMMON/OUT/

COMMON/WPARR/

COMMON/WPARR/ 


\section{APPENDIX C}

\section{EXAMPLES OF INPUT FILES FOR RIVER-RAD}

The first file given is RADIO.IN (see Table 2 in the text). Three different examples of the file WATER.IN follow (see Table 1 in the text).

This is file RADIO.IN. Additional radionuclides can be added to this file by following the instructions given in Table 2 . Note that an example using short-lived daughters is given for $\mathrm{U}-233$ (see below).

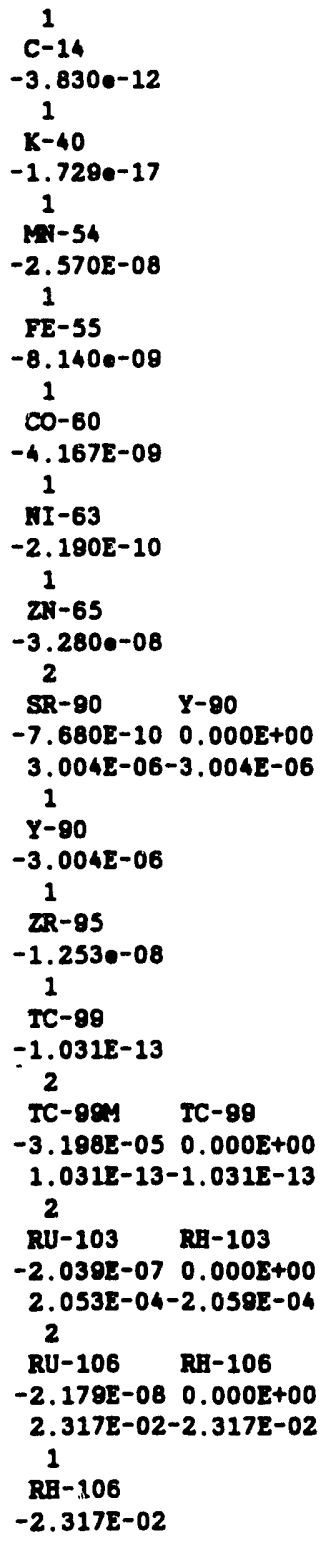




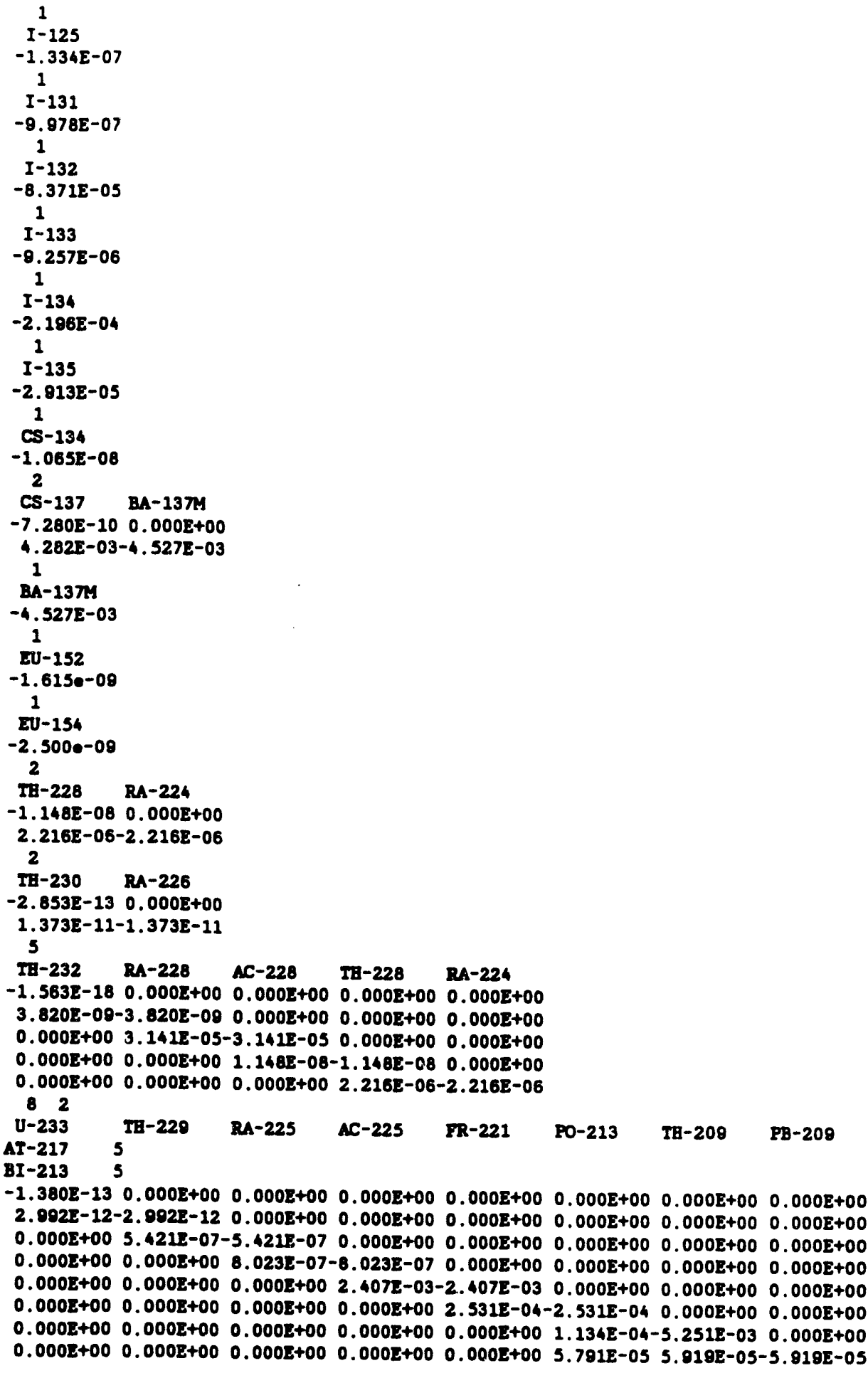


3

U-234 TH-230 RA-226

$-8.883 E-14 \quad 0.000 E+00 \quad 0.000 E+00$

2.853E-13-2.853E-13 $0.000 E+00$

$0.000 E+001.373 E-11-1.373 E-11$

7

$\begin{array}{lllllll}\text { U-235 } & \text { TB-231 } & \text { PA-231 } & A C-227 & \text { TH-227 } & \text { FR-223 } & \text { RA-223 }\end{array}$

$\begin{array}{lllllll}-3.121 E-17 & 0.000 E+00 & 0.000 E+00 & 0.000 E+00 & 0.000 E+00 & 0.000 E+00 & 0.000 E+00\end{array}$

7.545E-C6-7.545E-06 $0.000 E+00 \quad 0.000 E+00 \quad 0.000 E+00 \quad 0.000 E+00 \quad 0.000 E+00$

$0.000 E+W J$ S.89SE-13-5. B85E-13 $0.000 E+00 \quad 0.000 E+00 \quad 0.000 E+00 \quad 0.000 E+00$

$\begin{array}{llllll}0.000 E+00 & 0.000 E+00 & 1.009 E-08-1.009 E-09 & 0.000 E+00 & 0.000 E+00 & 0.000 E+00\end{array}$

$0.000 E+00 \quad 0.000 E+00 \quad 0.000 E+00 \quad .227 E-07-4.286 E-07 \quad 0.000 E+00 \quad 0.000 E+00$

$0.000 E+00 \quad 0.000 E+00 \quad 0.000 E+00 \quad 7.313 E-06 \quad 0.000 E+00-5.299 E-04 \quad 0.000 E+00$

$0.000 E+00 \quad 0.000 E+00 \quad 0.000 E+00 \quad 0.000 E+00 \quad 7.016 E-07 \quad 7.016 E-07-7.016 E-07$ 6

U-236 IE-232 RA-228 AC-228 TB-228 RA-224

$\begin{array}{llllll}-8.381 E-16 & 0.000 E+00 & 0.000 E+00 & 0.000 E+00 & 0.000 E+00 & 0.000 E+00\end{array}$

$1.563 E-18-1.563 E-18 \quad 0.000 E+00 \quad 0.000 E+00 \quad 0.000 E+00 \quad 0.000 E+00$

$0.000 \mathrm{E}+00 \quad 3.820 \mathrm{E}-09-3.820 \mathrm{E}-09 \quad 0.000 \mathrm{E}+00 \quad 0.000 \mathrm{E}+00 \quad 0.000 \mathrm{E}+00$

$0.000 E+00 \quad 0.000 z+00 \quad 3.141 E-05-3.141 E-05 \quad 0.000 z+00 \quad 0.000 E+00$

$0.000 \mathrm{E}+00 \quad 0.000 \mathrm{E}+00 \quad 0.000 \mathrm{E}+00 \quad 1.148 \mathrm{E}-08 \mathrm{E}-1.148 \mathrm{E}-08 \quad 0.000 \mathrm{E}+00$

$0.000 \mathrm{E}+00 \quad 0.000 \mathrm{E}+00 \quad 0.000 \mathrm{E}+00 \quad 0.000 \mathrm{E}+00 \quad 2.216 \mathrm{E}-06-2.216 \mathrm{E}-06$

7

U-238 TB-234 PA-234M PA-234 U-234 TH-230 RA-226

$\begin{array}{llllllllll}-4.916 E-18 & 0.000 E+00 & 0.000 E+00 & 0.000 E+00 & 0.000 E+00 & 0.000 E+00 & 0.000 E+00\end{array}$

$\begin{array}{llllll}3.329 E-07-3.329 E-07 & 0.000 E+00 & 0.000 E+00 & 0.000 E+00 & 0.000 E+00 & 0.000 E+00\end{array}$

$0.000 E+00 \quad 9.874 E-03-8.874 E-03 \quad 0.000 E+00 \quad 0.000 E+00 \quad 0.000 E+00 \quad 0.000 E+00$

$0.000 E+00 \quad 0.000 E+00 \quad 4.598 E-08-2.874 E-05 \quad 0.000 E+00 \quad 0.000 E+00 \quad 0.000 E+00$

$0.000 E+00 \quad 0.000 E+00 \quad 8.968 E-14 \quad 8.883 E-14-8.983 E-14 \quad 0.000 E+00 \quad 0.000 E+00$

$0.000 E+00 \quad 0.000 E+00 \quad 0.000 E+00 \quad 0.000 E+00 \quad 2.853 E-13-2.853 E-13 \quad 0.000 E+00$

$0.000 E+00 \quad 0.000 E+00 \quad 0.000 E+00 \quad 0.000 E+00 \quad 0.000 E+00 \quad 1.373 E-11-1.373 E-11$ 4

PU-238 U-234 TE-230 RA-226

$-2.503 \mathrm{E}-10 \quad 0.000 \mathrm{E}+00 \quad 0.000 \mathrm{E}+00 \quad 0.000 \mathrm{E}+00$

8.983E-14-8.983E-14 $0.000 E+00 \quad 0.000 E+00$

$0.000 \mathrm{E}+002.853 \mathrm{E}-13-2.853 \mathrm{E}-13 \quad 0.000 \mathrm{E}+00$

$0.000 E+00 \quad 0.000 E+00 \quad 1.373 E-11-1.373 E-11$

8

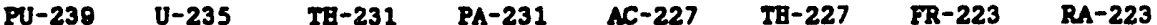

$\begin{array}{llllllllll}-0.102 E-13 & 0.000 E+00 & 0.000 E+00 & 0.000 E+00 & 0.000 E+00 & 0.000 E+00 & 0.000 E+00 & 0.000 E+00\end{array}$ $\begin{array}{llllllll}3.121 E-17-3.121 E-17 & 0.000 E+00 & 0.000 E+00 & 0.000 E+00 & 0.000 E+00 & 0.000 E+00 & 0.000 E+00\end{array}$ $\begin{array}{llllllll}0.000 E+00 & 7.545 \Sigma-06-7.545 E-06 & 0.000 E+00 & 0.000 E+00 & 0.000 E+00 & 0.000 E+00 & 0.000 E+00\end{array}$ $0.000 E+00 \quad 0.000 E+00 \quad 5.895 E-13-5.885 E-13 \quad 0.000 E+00 \quad 0.000 E+00 \quad 0.000 E+00 \quad 0.000 E+00$ $\begin{array}{lllllll}0.000 E+00 & 0.000 E+00 & 0.000 E+00 & 1.009 E-09-1.009 E-00 & 0.000 E+00 \quad 0.000 E+00 \quad 0.000 E+00\end{array}$ $0.000 E+00 \quad 0.000 E+00 \quad 0.000 E+00 \quad 0.000 E+00 \quad 4.227 E-07-4.286 E-07 \quad 0.000 E+00 \quad 0.000 E+00$ $\begin{array}{lllllll}0.000 E+00 & 0.000 E+00 & 0.000 E+00 & 0.000 E+00 & 7.313 E-06 & 0.000 E+00-5.289 E-04 & 0.000 E+00\end{array}$ $0.000 E+00 \quad 0.000 E+00 \quad 0.000 E+00 \quad 0.000 E+00 \quad 0.000 E+00 \quad 7.016 E-07 \quad 7.016 E-07-7.016 E-07$ 7

PU-240 U-236 TE-232 RA-228 AC-228 IE-228 RA-224

$\begin{array}{lllllllll}-3.344 E-12 & 0.000 E+00 & 0.000 E+00 & 0.000 E+00 & 0.000 E+00 & 0.000 E+00 & 0.000 E+00\end{array}$

9.381E-16-9.381z-16 $0.000 \mathrm{E}+00 \quad 0.000 \mathrm{E}+00 \quad 0.000 \mathrm{E}+00 \quad 0.000 \mathrm{E}+00 \quad 0.000 \mathrm{E}+00$

$0.000 E+001.563 E-18-1.563 E-18 \quad 0.000 E+00 \quad 0.000 E+00 \quad 0.000 E+00 \quad 0.000 E+00$

$0.000 \mathrm{E}+00 \quad 0.000 \mathrm{E}+00 \quad 3.820 \mathrm{E}-08-3.020 \mathrm{E}-08 \quad 0.000 \mathrm{E}+00 \quad 0.000 \mathrm{E}+00 \quad 0.000 \mathrm{E}+00$

$0.000 E+00 \quad 0.000 E+00 \quad 0.000 E+00 \quad 3.141 E-05-3.141 E-05 \quad 0.000 E+00 \quad 0.000 E+00$

$0.000 \mathrm{E}+00 \quad 0.000 \mathrm{E}+00 \quad 0.000 \mathrm{E}+00 \quad 0.000 \mathrm{E}+00 \quad 1.148 \mathrm{E}-08-1.148 \mathrm{E}-08 \quad 0.000 \mathrm{E}+00$

$0.000 \mathrm{E}+00 \quad 0.000 \mathrm{E}+00 \quad 0.000 \mathrm{E}+00 \quad 0.000 \mathrm{E}+00 \quad 0.000 \mathrm{E}+00 \quad 2.216 \mathrm{E}-0 \mathrm{E}-2.216 \mathrm{E}-06$ 3

AY-241 AP-237 PA-233

$-5.082 E-110.000 E+00 \quad 0.000 E+00$

$1.026 \mathrm{E}-14-1.026 \mathrm{E}-140.000 \mathrm{E}+00$

$0.000 E+002.971 E-07-2.971 E-07$

8

Q4-244 PU-240 U-236 IB-232 RA-228 AC-228 TB-228 RA-224

$\begin{array}{llllllllllll}-1.213 E-09 & 0.000 E+00 & 0.000 E+00 & 0.000 E+00 & 0.000 E+00 & 0.000 E+00 & 0.000 E+00 & 0.000 E+00\end{array}$ $3.344 E-12-3.344 E-12 \quad 0.000 E+00 \quad 0.000 E+00 \quad 0.000 E+00 \quad 0.000 E+00 \quad 0.000 E+00 \quad 0.000 E+00$ $\begin{array}{llllllll}0.000 E+00 & 9.381 E-16-9.381 E-16 & 0.000 E+00 & 0.000 E+00 & 0.000 E+00 & 0.000 E+00 & 0.000 E+00\end{array}$ $0.000 E+00 \quad 0.000 E+001.563 E-18-1.563 E-18 \quad 0.000 E+00 \quad 0.000 E+00 \quad 0.000 E+00 \quad 0.000 E+00$ $0.000 E+00 \quad 0.000 E+00 \quad 0.000 E+00 \quad 3.820 E-08-3.820 E-08 \quad 0.000 E+00 \quad 0.000 E+00 \quad 0.000 E+00$ $0.000 E+00 \quad 0.000 E+00 \quad 0.000 E+00 \quad 0.000 E+00 \quad 3.141 E-05-3.141 E-05 \quad 0.000 E+00 \quad 0.000 E+00$ $0.000 E+00 \quad 0.000 E+00 \quad 0.000 E+00 \quad 0.000 E+00 \quad 0.000 E+00 \quad 1.148 E-08-1.148 E-08 \quad 0.000 E+00$

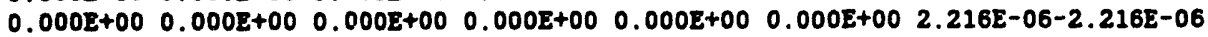


This is file WATER.IN (example 1). There is one parent (SR-90) with a source of $0.01 \mathrm{Ci} / \mathrm{s}$ each month for 1 year. The water velocity varies each month, there are 3 reaches with length of $5000.0 \mathrm{~m}$, width of $300.0 \mathrm{~m}$, and depth of $5.0 \mathrm{~m}$, the volatilization rates for the parent and daughter (Y-90) are assumed to be 0.0 , the distribution coefficient Kd (SWKDR) is given for each, and sediment parameters for Laursen's formula are given. Sediment compartment parameters are given on the last line - note that the settling velocity is 0.0 , so the code calculates it via subroutine VFALL. The output from RIVER-RAD corresponding to this input is given in Appendix D.

\begin{tabular}{|c|c|c|c|c|c|c|}
\hline $\begin{array}{l}\text { Or Mans JTes } \\
\text { moc }\end{array}$ & $\begin{array}{l}1 \\
1\end{array}$ & & & & & \\
\hline MUCLIDE WAE WUC & $\mathbf{s R}-\infty$ & & & & & \\
\hline 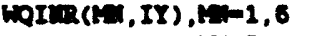 & 0.02 & 0.01 & 0.01 & 102 & 0.01 & 0.01 \\
\hline $\begin{array}{r}m=7.12 \\
\operatorname{minR}(1), I Y), 1=1.6\end{array}$ & $\begin{array}{r}0.02 \\
1.0\end{array}$ & $\begin{array}{r}0.01 \\
1.0\end{array}$ & $\begin{array}{r}0.01 \\
0.0\end{array}$ & $\begin{array}{r}0.01 \\
0.8\end{array}$ & $\begin{array}{r}0.02 \\
0.7\end{array}$ & $\begin{array}{r}0.01 \\
1.1\end{array}$ \\
\hline$=7,12$ & 1.0 & 0.9 & 1.5 & 1.4 & 1.3 & 1.5 \\
\hline $\mathbf{R}$ & 3 & & & & & \\
\hline 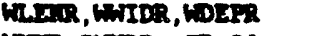 & 5000.0 & 300 & 5. & & & \\
\hline 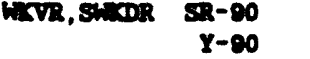 & $0.00 \mathrm{E}-0$ & $\begin{array}{l}3.5 z+1 \\
5.0 z+2\end{array}$ & & & & \\
\hline Thas stconrty & no & & & & & \\
\hline LAtresen'S PARAETERS & 2.65 & 1.0 & $7.5 z-5$ & & & \\
\hline SEDIRLART COSPA & .05 & 100. & 0.01 & 1000.0 & 0.0 & 0.00 \\
\hline
\end{tabular}


This is file WATER.IN (example 2). There are two parents (TH-232 and U-236), each with a source of $0.01 \mathrm{Ci} / \mathrm{s}$ every month for 1 year. The water velocity is constant at $1.5 \mathrm{~m} / \mathrm{s}$ each month, there are 3 reaches with length of $500.0 \mathrm{~m}$, width of $300.0 \mathrm{~m}$, and depth of $10.0 \mathrm{~m}$, the volatilization rates for the parents and daughters are assumed to be 0.0 , the distribution coefficients $\mathrm{Kd}$ (SWKDR) are given for each, and sediment parameters for Laursen's formula are given. Note that TH-232 must be first in this file because it appears before U-236 in file RADIO.IN . Also, the parameters WKVR and SWKDR are given for the TH-232 chain first (TH-232, RA-228, AC-228, TH-228, and RA-224), followed by the U-236 chain. They must be given in the same order that they appear in file RADIO.IN. The output from RIVER-RAD corresponding to this input is given in Appendix $D$.

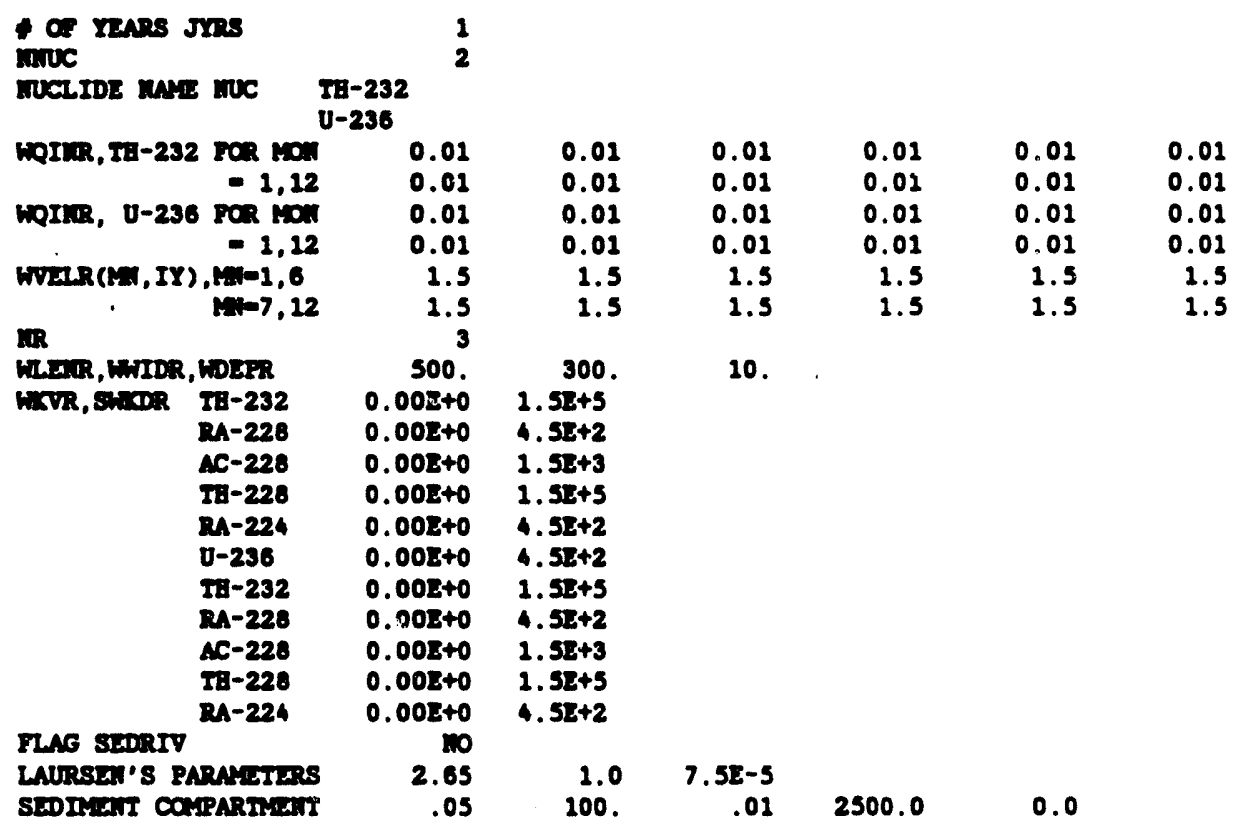


This is WATER.IN (example 3). There are ten parents, each with a source of 0.01 $\mathrm{Ci} / \mathrm{s}$ every month for 1 year. The water velocity is constant at $1.5 \mathrm{~m} / \mathrm{s}$ each month, there are 5 reaches with length of $500.0 \mathrm{~m}$, width of $300.0 \mathrm{~m}$, and depth of $10.0 \mathrm{~m}$, the volatilization rates are all assumed to be 0.0 , the distribution coefficients $\mathrm{Kd}$ (SWKDR) are given for each, and sediment concentrations are given for each month. Note that the radionuclides must be given in the order shown since they are in this order in file RADIO.IN (the same holds for the parameters WKVR and SWKDR). The output from RIVER-RAD corresponding to this input is given in Appendix D.

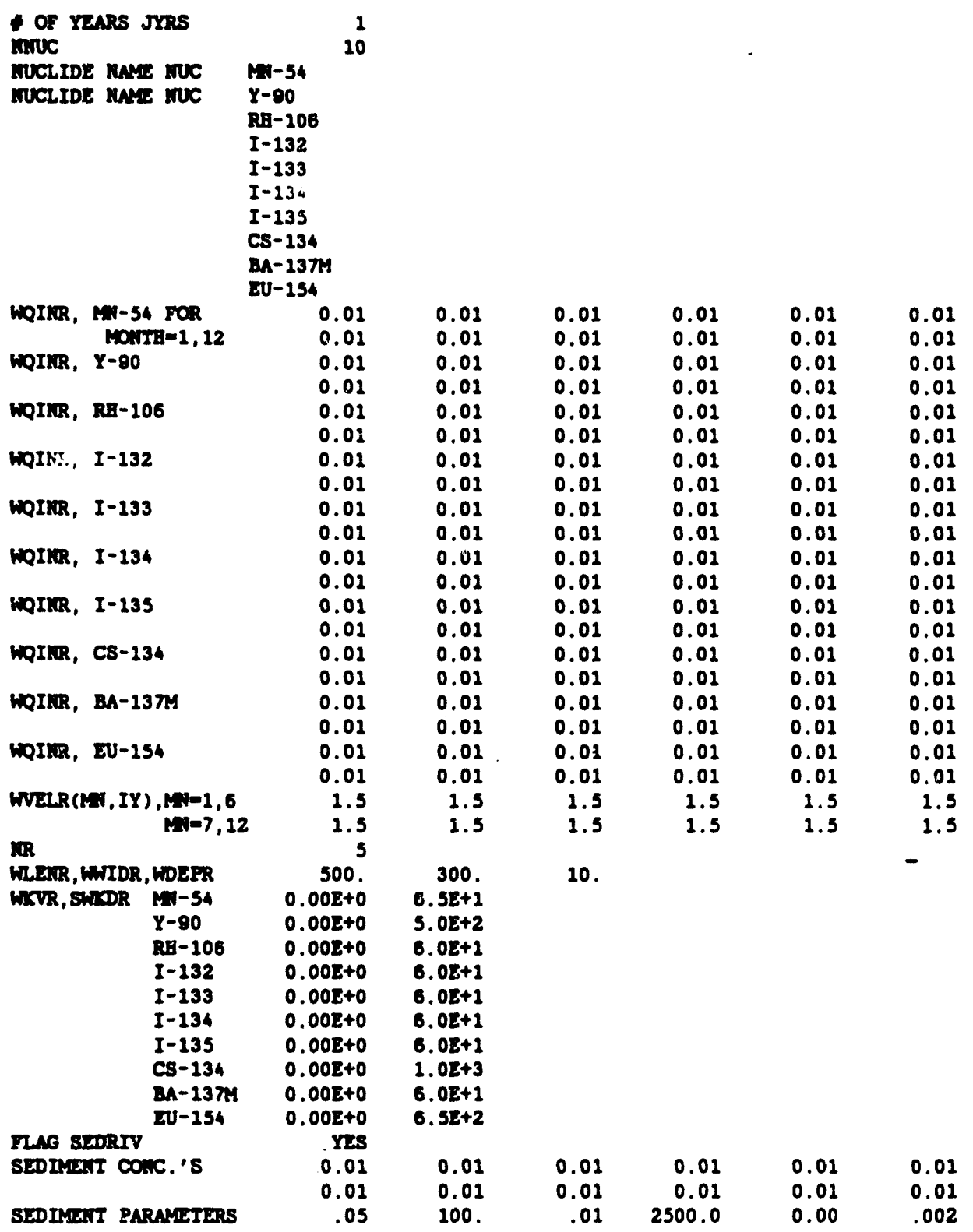




\section{APPENDIX D \\ RESULTS FROM THE RIVER-RAD MODEL}

These results correspond to the input data (examples 1, 2, and 3) given in Appendix C.

This is the file OUTPUT.USR that resulted from running RIVER-RAD using the input file WATER.IN (example 1) from Appendix C. The user should always check this Gile to make sure that all data were input correctly and for any warning or error messages.

INPUT DATA FOR AND IESSACES FROA TEE RTVER-RAD YODEL

\begin{tabular}{|c|c|c|c|}
\hline DEFIMITIOA & MAE & UAIT & VALUE(S) \\
\hline
\end{tabular}

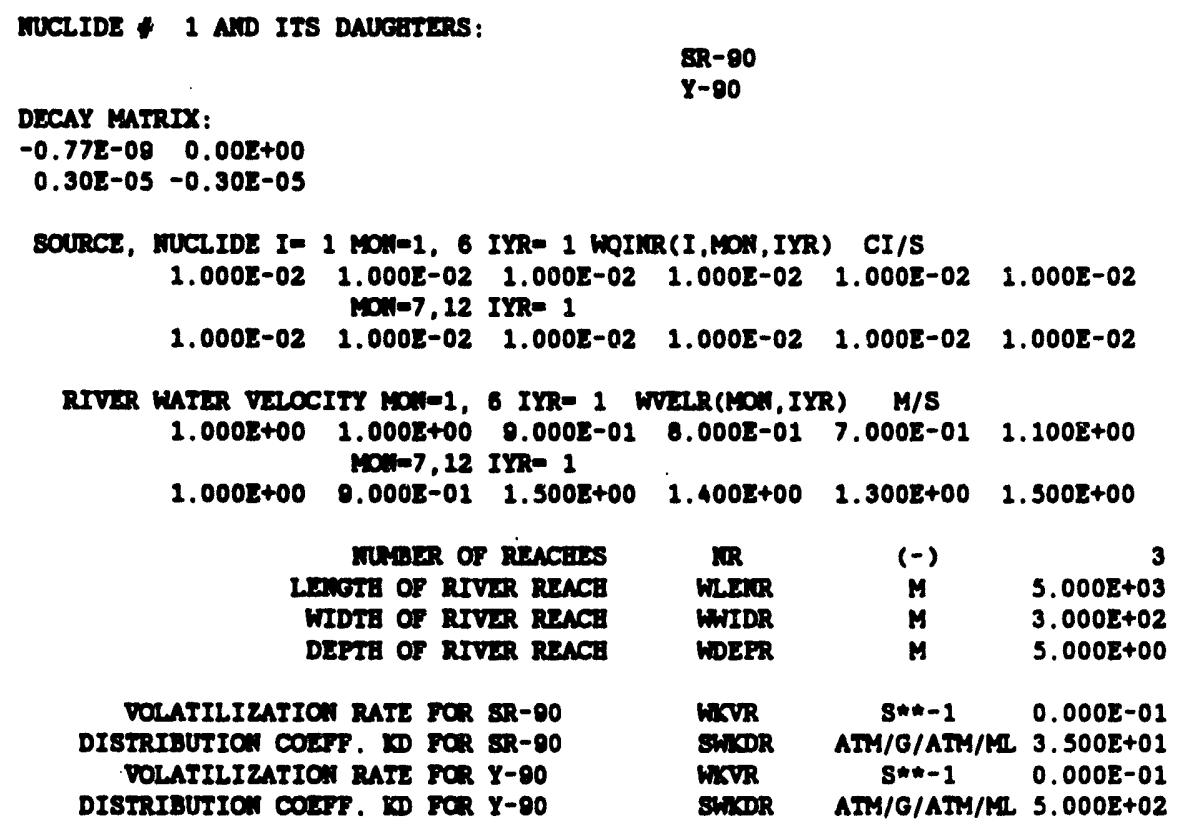

MODAL THE TRAT DETRPAINLS WAT USER IMPUTS

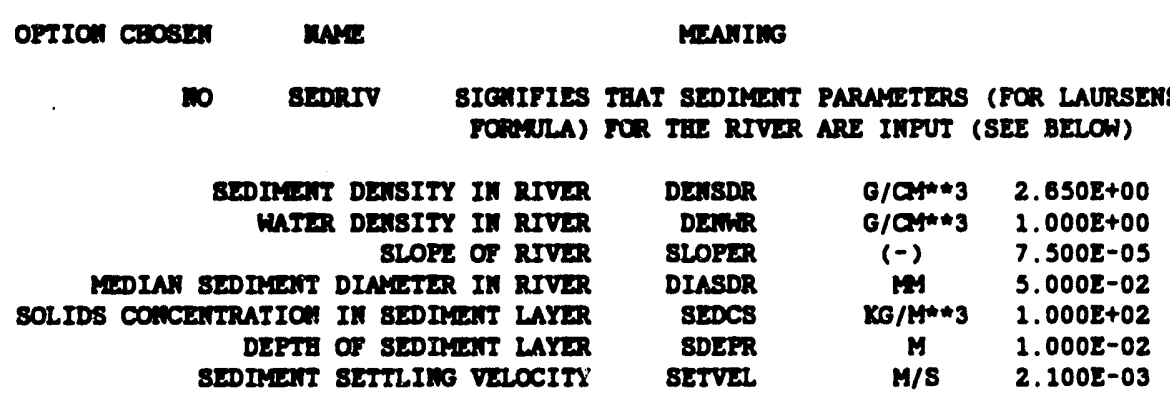


$\begin{array}{rlll}\text { SEDIMENT RESUSPENSION VELOCITY } & \text { RESVEL } & \text { MM/YR } & 1.000 E+03 \\ \text { SEDIMENTATION VELOCITY } & \text { SEDVEL } & \text { MM/YR } & 0.000 E-01\end{array}$

SCEMARIO

RIVER (BAS SOURCE)

MAEITUDE OF SOURCE(S)

$\begin{array}{llllll}\text { OCI } & \text { NOW } & \text { DEC } & \text { JAH } & \text { FEB } & \text { MAR } \\ \text { APR } & \text { MAY } & \text { JUA } & \text { JI } & \text { AUG } & \text { SEP }\end{array}$

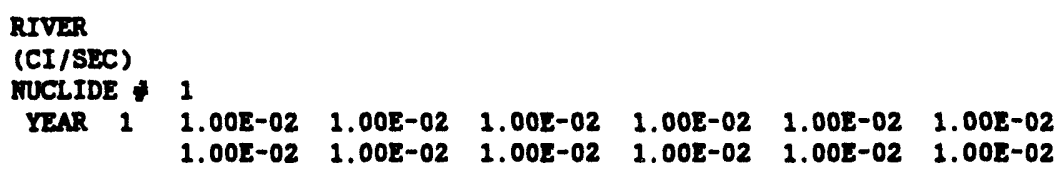

This is the file OUTPUT.RIV that resulted from running RIVER-RAD using the input file WATER.IN (example 1) from Appendix C. To conserve space, results from only the first and last months of the simulation are given.

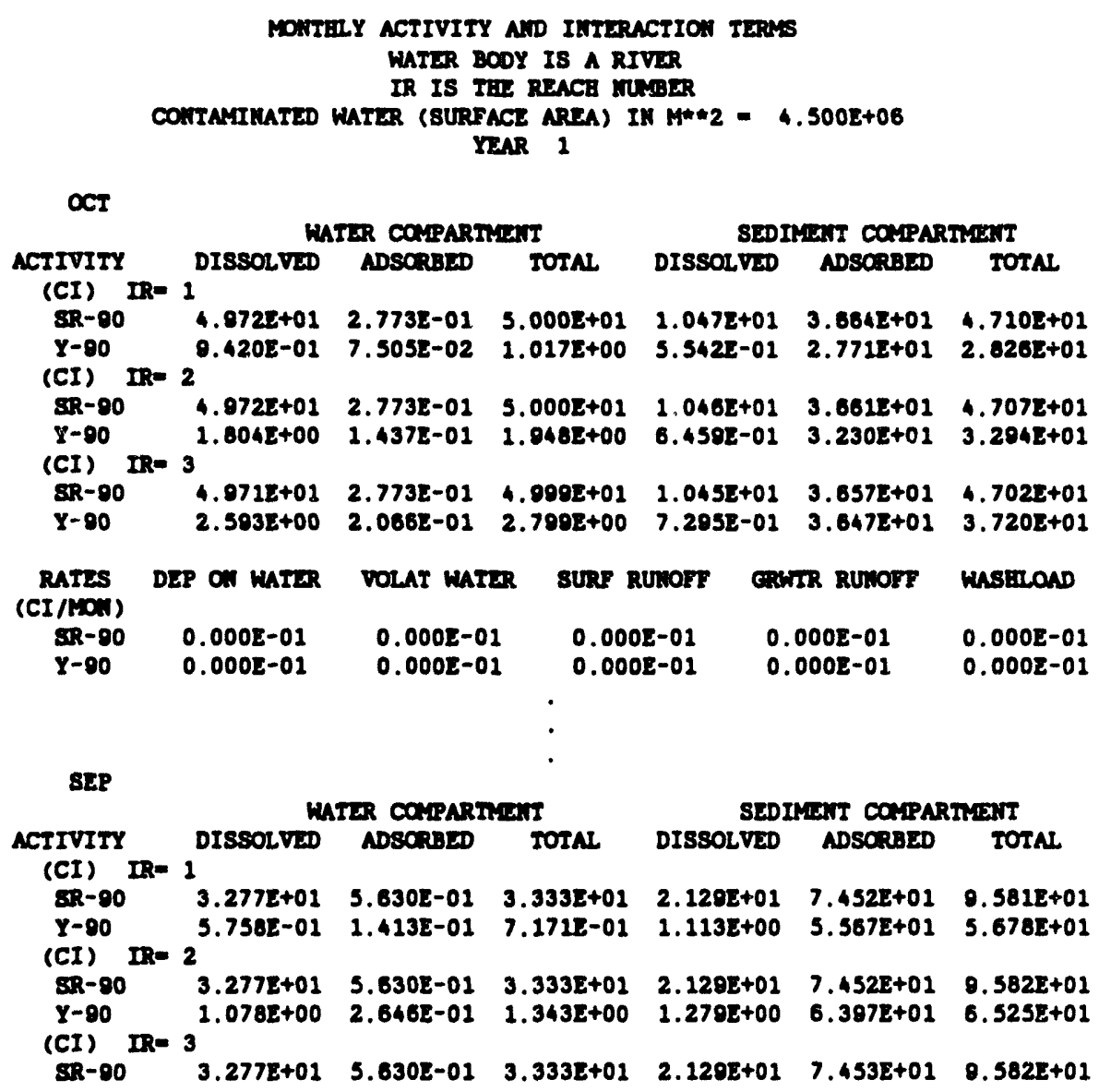




$\begin{array}{crccccc}\text { Y-90 } & 1.517 E+00 & 3.723 E-01 & 1.889 E+00 & 1.424 E+00 & 7.122 E+01 & 7.265 E+01 \\ \text { RATES } & \text { DEP ON WATER } & \text { VOLAT WATER } & \text { SURF RUNOFF } & \text { GRWTR RUNOFF } & \text { WASHLOAD } \\ \begin{array}{c}\text { (CI/MOS) } \\ \text { SR-90 }\end{array} & 0.000 E-01 & 0.000 E-01 & 0.000 E-01 & 0.000 E-01 & 0.000 E-01 \\ \text { Y-90 } & 0.000 E-01 & 0.000 E-01 & 0.000 E-01 & 0.000 E-01 & 0.000 E-01\end{array}$

This is the file OUTPUT.USR that resulted from running RIVER-RAD using the input file WATER.IN (example 2) from Appendix C. The user should always check this file to make sure that all data were input correctly and for any warning or error messages.

INPUT DATA FOR AND MESSAGES FROY TEE RIVER-RAD MODEL

$\begin{array}{lcrr}\text { DEFIMITION } & \text { MANE } & \text { UNIT } & \text { VALUE(S) } \\ \text { MUVBER OF YEARS } & \text { JYRS } & (-) & 1 \\ \text { MUMBER OF MUCLIDES } & \text { MNUC } & (-) & 2\end{array}$

MUCLIDE * 1 AND ITS DAUGATERS:

\begin{tabular}{|c|c|c|c|c|c|c|}
\hline & & & & $\begin{array}{l}\mathrm{TB}-232 \\
\mathrm{RA}-228 \\
\mathrm{AC}-228 \\
\mathrm{~TB}-228 \\
\mathrm{RA}-224\end{array}$ & & \\
\hline $\begin{array}{l}\text { DECAY MATR } \\
-0.16 \mathrm{E}-17 \\
0.38 \mathrm{E}-08 \\
0.00 \mathrm{E}+00 \\
0.00 \mathrm{E}+00 \\
0.00 \mathrm{0}+00\end{array}$ & $\begin{array}{l}R I X: \\
0.00 E+00 \\
-0.38 E-08 \\
0.31 E-04 \\
0.00 E+00 \\
0.00 E+00\end{array}$ & $\begin{array}{r}0.00 \mathrm{E}+00 \\
0.00 \mathrm{E}+00 \\
-0.31 \mathrm{E}-04 \\
0.11 \mathrm{E}-07 \\
0.00 \mathrm{E}+00\end{array}$ & $\begin{array}{r}0.00 E+00 \\
0.00 E+00 \\
0.00 E+00 \\
-0.11 E-07 \\
0.22 E-05-\end{array}$ & $\begin{array}{r}0.00 E+00 \\
0.00 E+00 \\
0.00 z+00 \\
0.00 E+00 \\
-0.22 E-05\end{array}$ & 更 & \\
\hline NUCLIDE * & 2 AND ITS & 5 DAUGHTERS: & : & $\begin{array}{l}\mathrm{U}-236 \\
\mathrm{~TB}-232 \\
\mathrm{RA}-228 \\
\mathrm{AC}-228 \\
\mathrm{~TB}-228 \\
\mathrm{RA}-224\end{array}$ & & \\
\hline $\begin{array}{c}\text { DECAY MATE } \\
-0.04 E-15 \\
0.16 E-17 \\
0.00 E+00 \\
0.00 E+00 \\
0.00 E+00 \\
0.00 E+00\end{array}$ & $\begin{array}{r}\text { RIX: } \\
0.00 \mathrm{E}+00 \\
-0.16 \mathrm{E}-17 \\
0.38 \mathrm{E}-0 \mathrm{~B} \\
0.00 \mathrm{E}+00 \\
0.00 \mathrm{E}+00 \\
0.00 \mathrm{E}+00\end{array}$ & $\begin{array}{r}0.00 \mathrm{E}+00 \\
0.00 \mathrm{E}+00 \\
-0.38 \mathrm{E}-08 \\
0.31 \mathrm{E}-04 \\
0.00 \mathrm{E}+00 \\
0.00 \mathrm{E}+00\end{array}$ & $\begin{array}{r}0.00 E+00 \\
0.00 z+00 \\
0.00 E+00 \\
-0.31 E-04 \\
0.11 E-07- \\
0.00 E+00\end{array}$ & $\begin{array}{r}0.00 E+00 \\
0.00 E+00 \\
0.00 E+00 \\
0.00 E+00 \\
-0.11 E-07 \\
0.22 E-05\end{array}$ & $\begin{array}{r}0.00 \mathrm{E}+00 \\
0.00 \mathrm{E}+00 \\
0.00 \mathrm{E}+00 \\
0.00 \mathrm{E}+00 \\
0.00 \mathrm{E}+00 \\
-0.22 \mathrm{E}-05\end{array}$ & \\
\hline SOURCE, & $\begin{array}{l}\text { RUCLIDE IE } \\
1.000 \mathrm{E}-02 \\
1.000 \mathrm{E}-02\end{array}$ & $\begin{array}{r}1 \mathrm{HON}-1,6 \\
1.000 \mathrm{E}-02 \\
1 \mathrm{ON}=7,12 \\
1.000 \mathrm{E}-02\end{array}$ & $\begin{array}{l}\text { IYR }=1 \mathrm{hQI} \\
1.000 \mathrm{E}-02 \\
\mathrm{IYR}=1 \\
1.000 \mathrm{E}-02\end{array}$ & $\begin{array}{ll}\operatorname{INR}(I, \mathrm{MON}, \\
2 & 1.000 \mathrm{E}-1 \\
2 & 1.000 \mathrm{E}-\end{array}$ & $\begin{array}{lc}. I Y R) & C I / S \\
-02 & 1.000 E-02 \\
-02 & 1.000 E-02\end{array}$ & $\begin{array}{l}1.000 \mathrm{E}-02 \\
1.000 \mathrm{E}-02\end{array}$ \\
\hline SOUDCE, & $\begin{array}{l}\text { RUCLIDE I= } \\
1.000 E-02 \\
1.000 E-02\end{array}$ & $\begin{array}{r}2.01-1,6 \\
1.000 z-02 \\
1.0008-12 \\
1.002-1.12\end{array}$ & $\begin{array}{l}I Y R=1 \mathrm{KQI} \\
1.000 \mathrm{~L}-02 \\
\mathrm{IYR}=1 \\
1.000 \mathrm{Z}-02\end{array}$ & 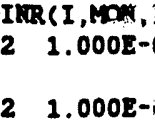 & $\begin{array}{ll}. I X(R) & C I / S \\
-02 & 1.000 E-02\end{array}$ & $1.000 \mathrm{E}-02$ \\
\hline RIVER & $\begin{array}{l}\text { HATER VELOC } \\
1.500 E+00 \\
1.500 E+00\end{array}$ & $\begin{array}{r}\text { CITY EON-1, } \\
1.500 \mathrm{E}+00 \\
\text { MON=7.12 } \\
1.500 \mathrm{E}+00\end{array}$ & $\begin{array}{l}6 \text { IYR }=1 \\
0.500 E+00 \\
2 I Y R=1 \\
0 \quad 1.500 E+00\end{array}$ & 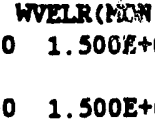 & $\begin{array}{cc}M, I Y R) & M / S \\
+00 & 1.500 E+00 \\
+\infty & 1.500 E+00\end{array}$ & $\begin{array}{l}1.500 E+00 \\
1.500 E+00\end{array}$ \\
\hline
\end{tabular}


NUMBER OF REACBES LENGTH OF RIVER REACE WIDTH OF RIVER REACE DEPTE OF RIVER REACB

\begin{tabular}{|c|c|c|}
\hline NR & $(-)$ & 3 \\
\hline WLENR & $\mathbf{M}$ & $5.000 \mathrm{E}+02$ \\
\hline WWIDR & M & $3.000 E+02$ \\
\hline WDEPR & M & $1.000 E+01$ \\
\hline WKVR & $s * \pm-1$ & $0.000 E-01$ \\
\hline SWKDR & ATM/G/ATM/ML & $1.500 E+05$ \\
\hline WKVR & $5 * \hbar-1$ & $0.000 E-01$ \\
\hline SWTDR & ATM/G/ATM/ML & 4. $500 E+02$ \\
\hline WKVR & $5 * \hbar-1$ & $0.000 E-01$ \\
\hline SWKDR & ATM/G/ATM/ML & $1.500 E+03$ \\
\hline WKVR & $5 * t-1$ & $0.000 E-01$ \\
\hline SWKDR & ATM/G/ATM/ML & $1.500 \mathrm{E}+05$ \\
\hline WKVR & $8 * t-1$ & $0.000 \mathrm{E}-01$ \\
\hline SWikDR & AXI/G/AMI/ML & 4. $500 \mathrm{E}+02$ \\
\hline $\begin{array}{l}\text { WKVR } \\
\text { SWKDR }\end{array}$ & $\begin{array}{c}S * \hbar-1 \\
A T M / G / A T M / M L\end{array}$ & $0.000 E-01$ \\
\hline
\end{tabular}

VOLATILIZATIOH RATE FOR TH-232 DISTRIBUTION COEFF. KD FOR TB-232 VOLATILIZATION RATE FOR RA-228 DISTRIBUTION COEFF. KD FOR RA-22B VOLATILIZATION RATE FOR AC-228 DISTRIBUTIOA COEFF. KD FOR AC-22B DOLATILIZATION RATE FOR TH-228 DISTRIBUTIOA COEFF. UD FOR TE-22B VOLATILIZATION RATE FOR RA-224 DISIRIBUTIOA COEFF. WD FOR RA-224 VOLATILIZATION RATE FOR U-236 DISTRIBUTION COEFF. KD FOR U-236

MODEL FLAG TBAT DETERMINES WAAT USER IMPUTS

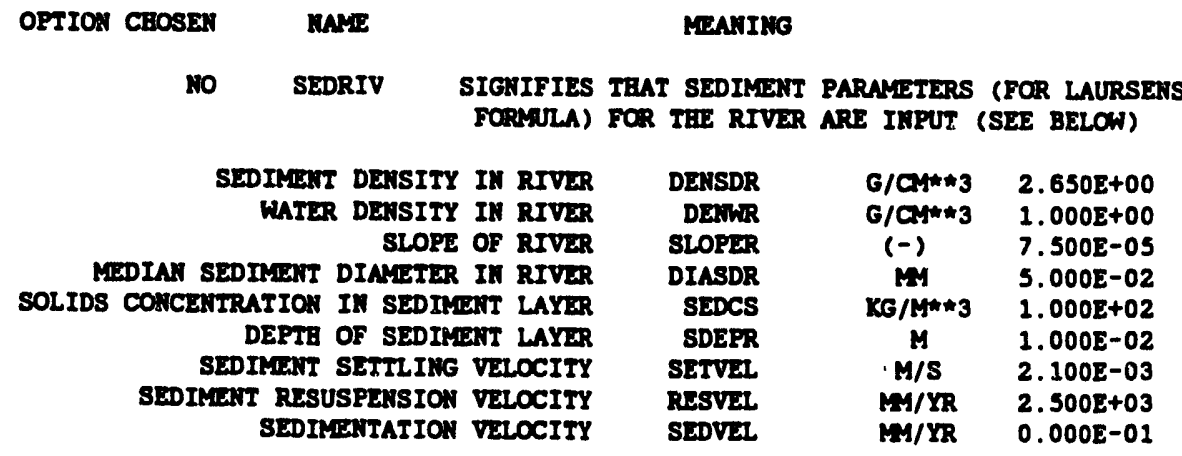

SCMARIO

RIVER (BAS SOURCE)

MEATTIDE OF SOURCE(s)

$\begin{array}{llllll}\text { OCT } & \text { MON } & \text { DEC } & \text { JAN } & \text { TEB } & \text { MAR } \\ \text { AFR } & \text { MAY } & \text { JUR } & \text { JUL } & \text { AUG } & \text { SEP }\end{array}$

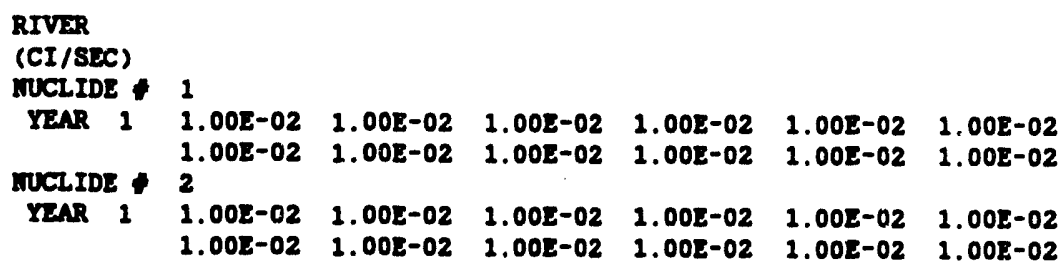


This is the file OUTPUT.RIV that resulted from running RIVER-RAD using the input file WATER.IN (example 2) from Appendix C. To conserve space, results from only the first and last months of the simulation are given. Note that in RIVER-RAD the results are summed by nuclide, regardless of the chains to which they belong.

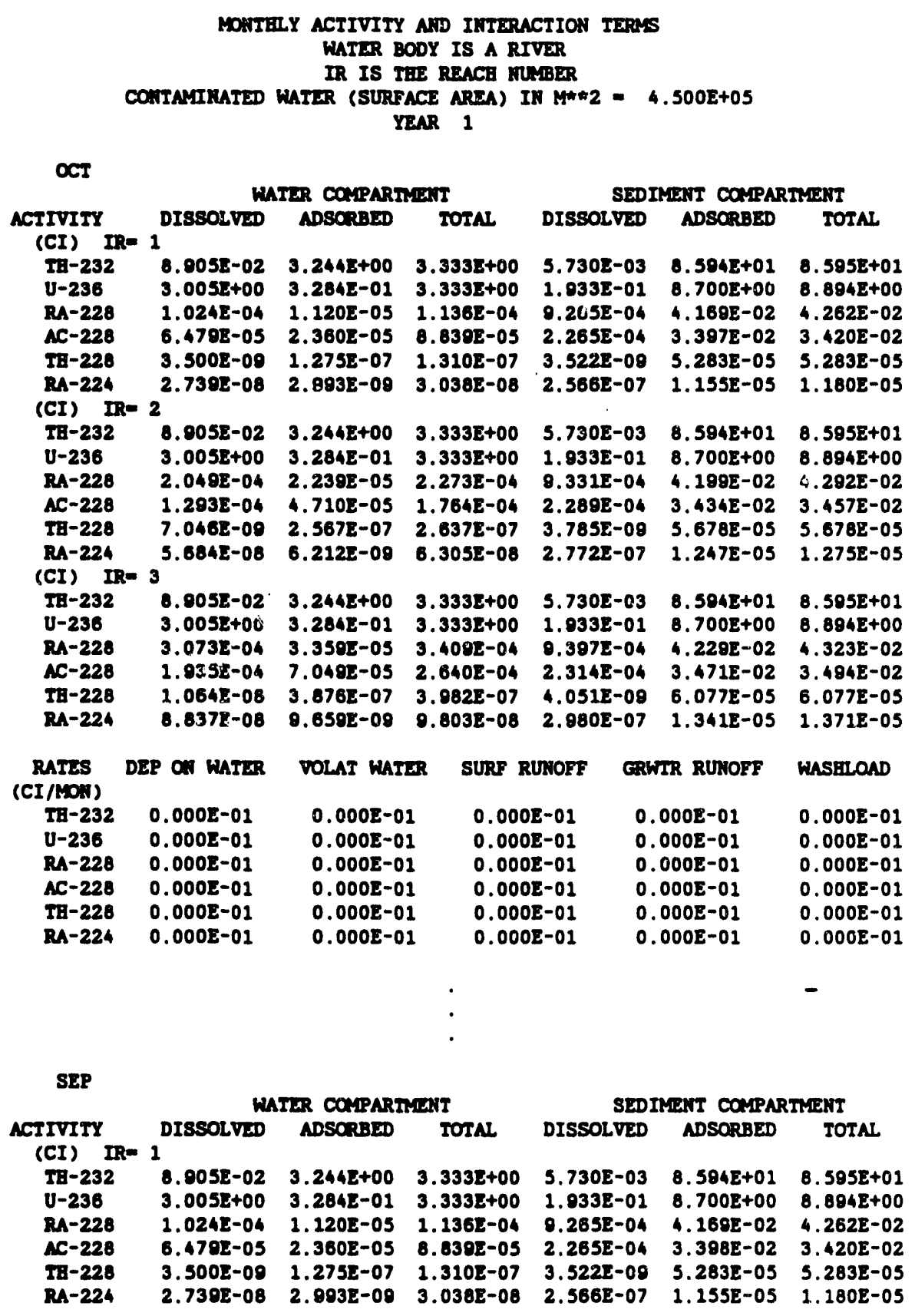




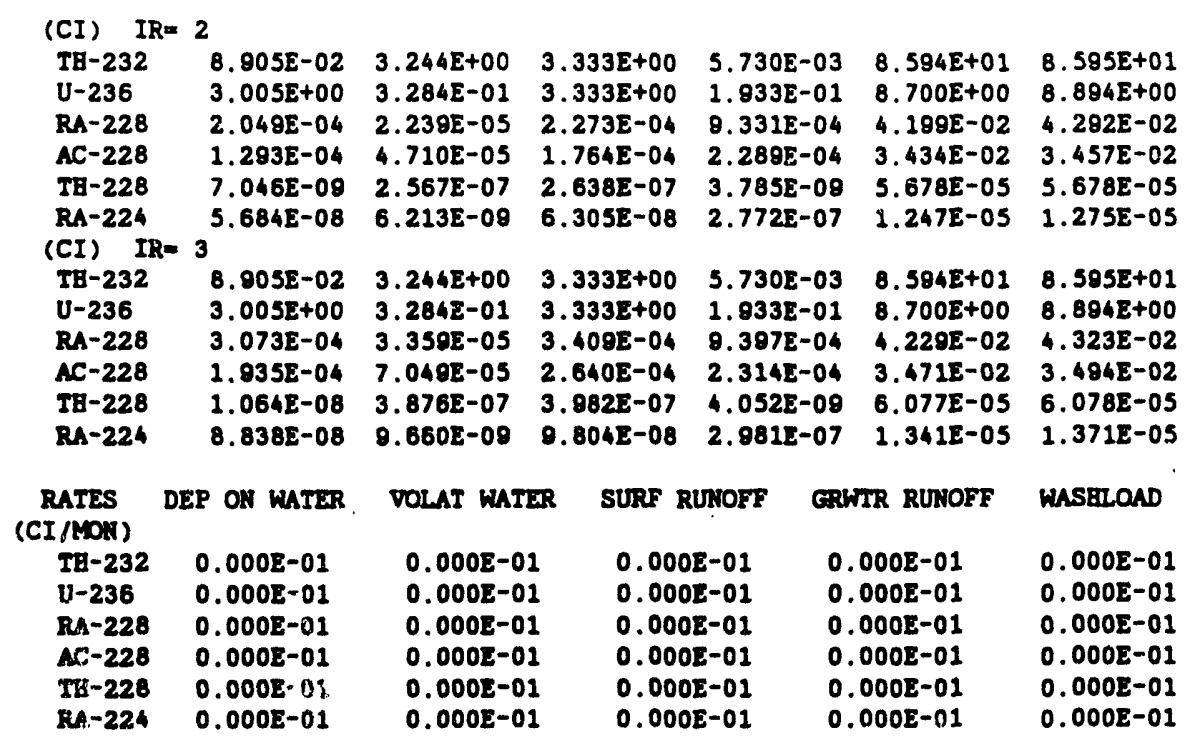

This is the file OUTPUT.USR that resulted from running RIVER-RAD using the input file WATER.IN (example 3) from Appendix C. The user should always check this file to make sure that all data were input correctly and for any warning or error messages.

IFPUI DATA FOR AND MESSAGES FROY TBE RIVER-RAD MODEL.

$\begin{array}{rrrr}\text { DEFINITION } & \text { MANE } & \text { UNIT } & \text { VALUE(S) } \\ \text { MUEBER OF YEARS } & \text { JYRS } & (-) & 1 \\ \text { MUNBER OF NUCLIDES } & \text { MNUC } & (-) & 10\end{array}$

RUCLIDE * 1 AND ITS DAUGETERS:

DECAY MATRIX:

Mat

$-0.26 E-07$

NUCTIDE - 2 AND ITS DAUGHTERS:

DECAY MATRIX:

$\mathbf{Y}-90$

$-0.30 \mathrm{E}-05$

MUCLIDE - 3 AND ITS DAUGATERS:

DECAY MARIX:

RB-106

$-0.23 E-01$

NUCLIDE + AND ITS DAUEATERS:

DECAY MATRX:

I-132

$-0.86 \mathrm{E}-04$

MUCLIDE * 5 AND ITS DAUGHTERS:

DECAY MTRIX:

I-133

$-0.03 E-05$

MUCLIDE * 6 AND ITS DAUGRTERS:

DECAY MATRIX:

$I-134$ 
$-0.22 E-03$

NUCLIDE 7 AND ITS DAUGHTERS:

DECAY MATRIX:

I-135

$-0.29 E-04$

NUCLIDE 8 AND ITS DAUGETERS:

DECAY MATRIX:

CS-134

$-0.11 \mathrm{E}-07$

NUCLIDE 19 AND ITS DAUGRTERS:

DECAX MARIX:

BA-137M

$-0.45 E-02$

RUCLIDE * 10 AND ITS DAUGHTERS:

DECAY MATRIX:

EU-154

$-0.25 E-08$

SOURCE, NUCLIDE I= $1 \mathrm{MOH}=1,6 \mathrm{IYR}=1 \mathrm{WQINR}$ (I,MON,IYR) $\mathrm{CI} / \mathrm{S}$

$\begin{array}{llllll}1.000 E-02 & 1.000 E-02 & 1.000 E-02 & 1.000 E-02 & 1.000 E-02 & 1.000 E-02\end{array}$ MON=7, 12 IYR= 1

$\begin{array}{llllll}1.000 \mathrm{E}-02 & 1.000 \mathrm{E}-02 & 1.000 \mathrm{E}-02 & 1.000 \mathrm{E}-02 & 1.000 \mathrm{E}-02 & 1.000 \mathrm{E}-02\end{array}$

SOURCE, NUCLIDE I= 2 MON=1, 6 IYR= $1 \mathrm{MQIRR}(\mathrm{I}, \mathrm{MON}, \mathrm{IYR}$ ) CI/S

$\begin{array}{lllllll}1.000 \mathrm{E}-02 & 1.000 \mathrm{E}-02 & 1.000 \mathrm{E}-02 & 1.000 \mathrm{E}-02 & 1.000 \mathrm{E}-02 & 1.000 \mathrm{E}-02\end{array}$ MON=7,12 IYR= 1

$\begin{array}{llllll}1.000 \mathrm{E}-02 & 1.000 \mathrm{E}-02 & 1.000 \mathrm{E}-02 & 1.000 \mathrm{E}-02 & 1.000 \mathrm{E}-02 & 1.000 \mathrm{E}-02\end{array}$

SOURCE, NUCLIDE I= 3 MON=1, 6 IYR= $1 \mathrm{WQIRR}$ (I, MON,IYR) $\mathrm{CI} / \mathrm{S}$

$\begin{array}{llllll}1.000 \mathrm{E}-02 & 1.000 \mathrm{E}-02 & 1.000 \mathrm{E}-02 & 1.000 \mathrm{E}-02 & 1.000 \mathrm{E}-02 & 1.000 \mathrm{E}-02\end{array}$ $M O N=7,12$ IYR= 1

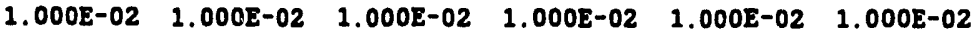

SOURCE, RUCLIDE I= MON=1, 6 IYR $=1$ WOIKR(I,MON,IYR) $\mathrm{CI} / \mathrm{S}$

$\begin{array}{llllll}1.000 E-02 & 1.000 E-02 & 1.000 E-02 & 1.000 E-02 & 1.000 E-02 & 1.000 E-02\end{array}$ $M O N=7,12$ IYR= 1

$\begin{array}{llllll}1.000 E-02 & 1.000 E-02 & 1.000 E-02 & 1.000 E-02 & 1.000 E-02 & 1.000 E-02\end{array}$

SOURCE, HUCLIDE I= $5 \mathrm{MON}=1,6 \mathrm{IYR}=1 \mathrm{WOIKR}$ (I,MON,IYR) $\mathrm{CI} / \mathrm{S}$

$\begin{array}{llllll}1.000 E-02 & 1.000 E-02 & 1.000 E-02 & 1.000 E-02 & 1.000 E-02 & 1.000 E-02\end{array}$ MON=7,12 IYR= 1

$\begin{array}{llllll}1.000 \mathrm{E}-02 & 1.000 \mathrm{E}-02 & 1.000 \mathrm{E}-02 & 1.000 \mathrm{E}-02 & 1.000 \mathrm{E}-02 & 1.000 \mathrm{E}-02\end{array}$

SOURCE, WUCLIDE I= 6 MON=1, 6 IYR= 1 WOIRR(I,MON,IYR) CI/S

$\begin{array}{llllll}1.000 E-02 & 1.000 \mathrm{E}-02 & 1.000 \mathrm{E}-02 & 1.000 \mathrm{E}-02 & 1.000 \mathrm{E}-02 & 1.000 \mathrm{E}-02\end{array}$ $\mathrm{MON}=7,12$ IYR=

$\begin{array}{lllllll}1.000 \mathrm{E}-02 & 1.000 \mathrm{E}-02 & 1.000 \mathrm{E}-02 & 1.000 \mathrm{E}-02 & 1.000 \mathrm{E}-02 & 1.000 \mathrm{E}-02\end{array}$

SOURCE, MUCLIDE I= 7 MON=1, 6 IYR= $1 \mathrm{KOIKR}$ (I, MON,IYR) $\mathrm{CI} / \mathrm{S}$

$\begin{array}{lllllll}1.000 E-02 & 1.000 E-02 & 1.000 E-02 & 1.000 E-02 & 1.000 E-02 & 1.000 E-02\end{array}$ $M O N=7,12$ IYR $=1$

$\begin{array}{llllll}1.000 E-02 & 1.000 E-02 & 1.000 E-02 & 1.000 E-02 & 1.000 E-02 & 1.000 E-02\end{array}$

SOURCE, NUCLIDE I= 8 MON=1, $6 \mathrm{IYR}=1 \mathrm{WQIKR}(I, \mathrm{MON}, I Y R$ ) $\mathrm{CI} / \mathrm{S}$

$\begin{array}{lllllll}1.000 \mathrm{E}-02 & 1.000 \mathrm{E}-02 & 1.000 \mathrm{E}-02 & 1.000 \mathrm{E}-02 & 1.000 \mathrm{E}-02 & 1.000 \mathrm{E}-02\end{array}$ $M O N=7,12$ IYR= 1

$\begin{array}{llllll}1.000 E-02 & 1.000 E-02 & 1.000 E-02 & 1.000 E-02 & 1.000 E-02 & 1.000 E-02\end{array}$ 
SOURCE, WUCLIDE I= $9 \mathrm{MON}=1,6 \mathrm{IYR}=1 \mathrm{WQINR}(\mathrm{I}, \mathrm{MON}, \mathrm{IYR}) \mathrm{CI} / \mathrm{S}$

$\begin{array}{llllll}1.000 \mathrm{E}-02 & 1.000 \mathrm{E}-02 & 1.000 \mathrm{E}-02 & 1.000 \mathrm{E}-02 & 1.000 \mathrm{E}-02 & 1.000 \mathrm{E}-02\end{array}$ MON=7,12 IYR= 1

$\begin{array}{llllll}1.000 E-02 & 1.000 E-02 & 1.000 E-02 & 1.000 E-02 & 1.000 E-02 & 1.000 E-02\end{array}$

SOURCE, MUCLIDE I=10 MON=1, 6 IYR= $1 \mathrm{mQIKR}(I, M O N, I Y R$ ) $C I / S$

$\begin{array}{llllll}1.000 \mathrm{E}-02 & 1.000 \mathrm{E}-02 & 1.000 \mathrm{E}-02 & 1.000 \mathrm{E}-02 & 1.000 \mathrm{E}-02 & 1.000 \mathrm{E}-02\end{array}$

MOi=7,12 IYR= 1

$\begin{array}{llllll}1.000 \mathrm{E}-02 & 1.000 \mathrm{E}-02 & 1.000 \mathrm{E}-02 & 1.000 \mathrm{E}-02 & 1.000 \mathrm{E}-02 & 1.000 \mathrm{E}-02\end{array}$

RIVER WATER VEOCITY WOR=1, 6 IYR= 1 WVELR(MON,IYR) M/S

$\begin{array}{llllll}1.500 E+00 & 1.500 E+00 & 1.500 E+00 & 1.500 E+00 & 1.500 E+00 & 1.500 E+00\end{array}$

$M=1=7,12$ IYR=

$\begin{array}{cccccc}1.500 \mathrm{E}+00 & 1.500 \mathrm{E}+00 & 1.500 \mathrm{E}+00 & 1.500 \mathrm{E}+00 & 1.500 \mathrm{E}+00 & 1.500 \mathrm{E}+00\end{array}$

RTRAR OF REACTES

WIDTR OF RTVA DEACA DEPTE OF RIVER REACE

VOLATILIZATIOA BATE FOR MA-54 DISTRIBUTION COEFF. ID FOR Mi-54 VOLATILIZATIO: RATE FOR Y-90 DISTRIBUTIOA COAT, ID POR $Y-90$ VOLATILIZATIOA RATE FOR RA-106 DISTRIBUTIOA COEAF. ID FCR RA-106 VOLATILIZATIOA RATE FOR I-132 DISTRIBUTIOA COEFF. UD POR I-132 VOLATILIZATIOA RATE EOR I-133 DISTRIBUTIOA COEFF. ID FCR I-133 volatILIzATIOA RATE FOR I-134 DISTRIBUTIOA COAFT. WD FOR I-134 VOLATILIZATIOA RATE POR I-135 DISTRIBUIICA COAFE. 10 FOR I-135 VOLATILIZATIOA RATE FOR CS-134 DISTRIBUTIOA COEFF. ID FOR CS-134 VOLATILIZATIOY RATL FOR BA-137M DISTRIBUTIOA COAFE. WD FOR BA-137M volatil.zatIOA RATE FOR EU-154 DISIRIBUTION COAFF. ID FOR EU-154
LENTSt of RTVA REACE

\begin{tabular}{|c|c|c|}
\hline RR & $(-)$ & 5 \\
\hline WLERTR & $M$ & $5.000 \mathrm{E}+02$ \\
\hline KNIDR & $\mathbf{M}$ & $3.000 \mathrm{E}+02$ \\
\hline WDEPR & $\mathbf{M}$ & $1.0003+01$ \\
\hline Wrin & $8 * t-1$ & $0.0005-01$ \\
\hline SWDR & AIM/G/ATM/ML & $6.500 E+01$ \\
\hline WKVR & $S * m-1$ & $0.0002-01$ \\
\hline Shisor & AMM/G/AIM/ML & $5.0002+02$ \\
\hline WKVR & $8 * m-1$ & $0.000 \mathrm{E}-01$ \\
\hline SWGDR & AIH/G/AIY/ML & $6.0002+01$ \\
\hline WISR & $s * t-1$ & $0.000 \mathrm{E}-01$ \\
\hline SMTDR & AXY/G/AXY/ML & $6.0002+01$ \\
\hline WSVR & $8 m-1$ & $0.000 \mathrm{~B}-01$ \\
\hline SHKDR & ATM/G/ATM/ML & $6.000 E+01$ \\
\hline WSVR & $s * t-1$ & $0.0002-01$ \\
\hline $\operatorname{SinDR}$ & AIM/G/AIM/MU & $6.000 E+01$ \\
\hline MSVR & $5 * m-1$ & $0.000 \mathrm{E}-01$ \\
\hline SETSDR & ATY/G/ATM/ML & $6.0002+01$ \\
\hline MSVR & $s * t-1$ & $0.300 \mathrm{E}-01$ \\
\hline $\sin \operatorname{spR}$ & ATM/G/ATH/ML & $1.0002+03$ \\
\hline MSVR & $8^{* *-1}$ & $0.000 E-01$ \\
\hline SinidR & AHI/G/A2M/ML & $6.0002+01$ \\
\hline $\begin{array}{l}\text { WuVR } \\
\text { SWITd }\end{array}$ & $\begin{array}{c}\text { Shth-1 } \\
\text { ATI/G/ATH/ML. }\end{array}$ & $\begin{array}{l}0.000 E-01 \\
6.500 E+02\end{array}$ \\
\hline
\end{tabular}

WODAL FLAG TBAT DETEPAIIES WBAT USER INPUTS

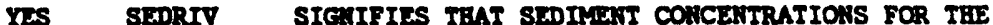
RIVAR ARE INPUT (SEE BALN)

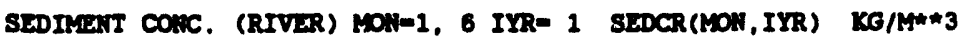

$$
\begin{aligned}
& \text { 1.000E-02 1.000E-02 } 1.000 \text { E-02 } 1.000 \mathrm{E}-02 \quad 1.000 \mathrm{E}-02 \quad 1.000 \mathrm{E}-02 \\
& \text { rom7.12 IYRe } 1
\end{aligned}
$$

$\begin{array}{llllll}1.000 \mathrm{E}-02 & 1.000 \mathrm{E}-02 & 1.000 \mathrm{E}-02 & 1.000 \mathrm{E}-02 & 1.000 \mathrm{E}-02 & 1.000 \mathrm{E}-02\end{array}$

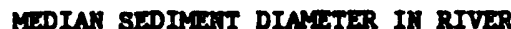

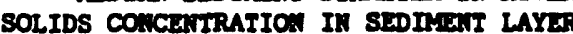
DEPIE of SEDTMIAT LAYAR SEDIMAT SEITLING VHocITY STDIMAIT REsuspansion viocity smiriration vacciry
DIASDR

SEDCS

SDEFR

SIIVI

BDSVA.

SEVIx.
M $\mathrm{KG} / \mathrm{M} * 3 \quad 1.000 \mathrm{E}+02$

M $\quad 1.000 \mathrm{E}-02$

M/S 2.000E-03

MY/YR 2.500E+03

YY/YR $\quad 0.000 E-01$ 
RIVAR (BAS SOURCE)

MANITUDE OF SOURCE(S)

$\begin{array}{llllll}\text { OCT } & \text { NOV } & \text { DEC } & \text { JAN } & \text { FEB } & \text { MAR } \\ \text { APR } & \text { MAY } & \text { JUN } & \text { JUL } & \text { AUG } & \text { SEP }\end{array}$

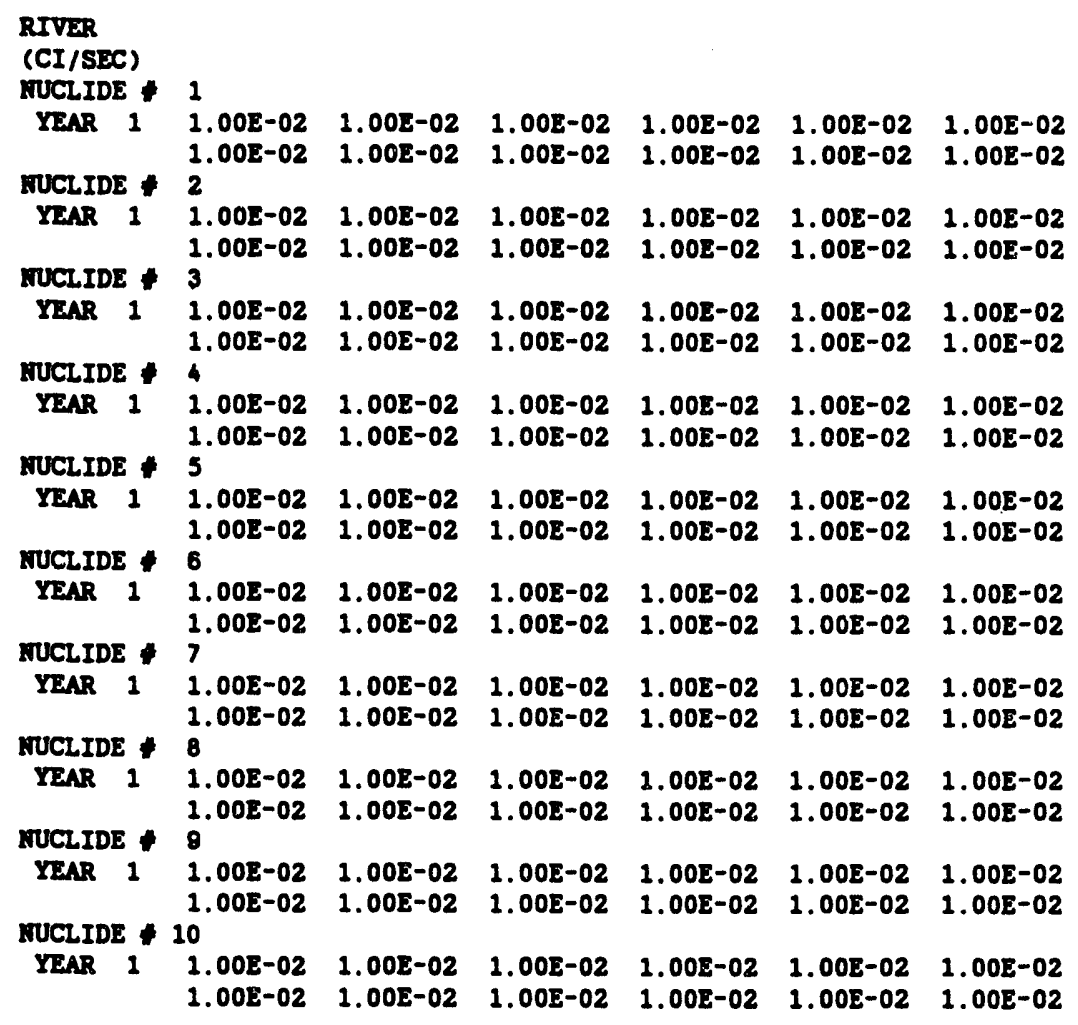


This is the file OUTPUT.RIV that resulted from running RIVER-RAD using the input file WATER.IN (example 3) from Appendix C. To conserve space, results from only the first and last months of the simulation are given.

MONTELY ACTIVITY AND INTERACTION TERUS

WATER BODY IS A RIVER

IR IS TEE REACE WUEBER

CORTAMIMATED WATER (SURFACE AREA) IN M"*2 $=7.500 E+05$

YEAR 1

\begin{tabular}{|c|c|c|c|c|c|c|}
\hline \multicolumn{6}{|l|}{ OCI } & MLEAT \\
\hline TIVITY & DISSOLVED & ADSORBED & TOTAL & DISSOLVED & ADSORBED & TOTAL \\
\hline (CI) $\mathrm{IR}=$ & & & & & & \\
\hline $\begin{array}{l}127-54 \\
Y-90\end{array}$ & $\begin{array}{l}3.331 E+00 \\
3.313 E+00\end{array}$ & $\begin{array}{l}2.165 \mathrm{E}-03 \\
1.857 \mathrm{E}-02\end{array}$ & $\begin{array}{l}3.333 z+00 \\
3.330 z+00\end{array}$ & $\begin{array}{l}8.373 E-03 \\
6.029 E-03\end{array}$ & $\begin{array}{l}5.442 E-02 \\
3.014 E-01\end{array}$ & $\begin{array}{l}6.280 E-02 \\
3.075 E-01\end{array}$ \\
\hline $\begin{array}{l}R B-106 \\
I-132\end{array}$ & $\begin{array}{l}3.819 E-01 \\
3.2418+00\end{array}$ & $\begin{array}{l}2.201 E-04 \\
1.044 E-03\end{array}$ & $\begin{array}{l}3.8218-01 \\
3.2438+00\end{array}$ & $\begin{array}{l}2.825 E-07 \\
6.138 E-04\end{array}$ & $\begin{array}{l}1.685 E-06 \\
3.683 E-03\end{array}$ & $\begin{array}{l}1.977 E-06 \\
4.297 E-03\end{array}$ \\
\hline$I-133$ & $3.3211 x+00$ & $1.983 \mathrm{E}-03$ & $3.3238+00$ & $3.547 \mathrm{E}-03$ & $2.128 \mathrm{E}-02$ & $2.483 E-02$ \\
\hline$I-134$ & $104 E+00$ & $1.862 \mathrm{E}-03$ & $3.1065+00$ & $.3508-04$ & $1.410 \mathrm{E}-03$ & $1.645 E-03$ \\
\hline $\begin{array}{l}I-135 \\
C S-134\end{array}$ & $\begin{array}{l}3.209 z+00 \\
3.300 z+00\end{array}$ & $\begin{array}{l}1.980 \mathrm{E}-03 \\
3.300 \mathrm{E}-02\end{array}$ & $\begin{array}{l}3.301 E+00 \\
3.333 E+00\end{array}$ & $\begin{array}{l}1.574 E-03 \\
8.315 E-03\end{array}$ & $\begin{array}{l}8.446 E-03 \\
8.315 E-01\end{array}$ & $\begin{array}{l}1.102 E-02 \\
8.398 E-01\end{array}$ \\
\hline $\begin{array}{l}\mathrm{BA}-13 \mathrm{M} \\
\mathrm{EU}-154\end{array}$ & $\begin{array}{r}1.328 z+00 \\
3.3128 E+00\end{array}$ & $\begin{array}{l}7.086 E-04 \\
2.153 E-02\end{array}$ & $\begin{array}{l}1.328 E+00 \\
3.333 E+00\end{array}$ & $\begin{array}{l}5.020 \mathrm{E}-06 \\
8.353 \mathrm{E}-03\end{array}$ & $\begin{array}{l}3.012 E-05 \\
5.428 E-01\end{array}$ & $\begin{array}{l}3.516 E-05 \\
5.513 E-01\end{array}$ \\
\hline (CI) $\mathrm{IR}=$ & & & & & & \\
\hline$w-54$ & $3.3318+00$ & . $165 E-03$ & $3.333 \mathrm{E}+00$ & $8.373 E-03$ & $5.442 E-02$ & $6.280 \mathrm{E}-02$ \\
\hline $\begin{array}{l}Y-80 \\
R B-106\end{array}$ & & & $\begin{array}{l}3.326 \mathrm{E}+00 \\
4.380 \mathrm{E}-02\end{array}$ & $\begin{array}{l}6.0225-03 \\
3.238 \mathrm{E}-08\end{array}$ & & $\begin{array}{l}3.071 E-01 \\
2.267 E-07\end{array}$ \\
\hline$I-132$ & $3.153 \mathrm{E}+00$ & $1.892 E-03$ & $3.155 \mathrm{E}+00$ & $5.972 E-04$ & $3.583 E-03$ & $4.180 \mathrm{E}-03$ \\
\hline$I-133$ & $3112+00$ & $1.986 E-03$ & $3 E+00$ & $3.536 E-03$ & LE-02 & $2.475 E-02$ \\
\hline$I-134$ & $2.892 E+00$ & $1.735 E-03$ & $2.894 E+00$ & $2.180 \mathrm{E}-04$ & $4 E-03$ & $1.533 \mathrm{E}-03$ \\
\hline$I-135$ & $3.267 \mathrm{E}+00$ & $1.960 \mathrm{E}-03$ & $3.269 \mathrm{E}+00$ & $1.559 E-03$ & $8.355 E-03$ & $1.091 E-02$ \\
\hline $\begin{array}{l}\text { CS-134 } \\
B A-137 y\end{array}$ & $\begin{array}{l}3.300 E+00 \\
5.282 E-01\end{array}$ & $\begin{array}{l}E-02 \\
3 z-04\end{array}$ & $\begin{array}{r}\begin{array}{r}5 E+00 \\
5 E-01\end{array}\end{array}$ & $\begin{array}{l}8.315 E-03 \\
2.001 E-06\end{array}$ & $\begin{array}{l}8.315 E-01 \\
1.201 E-05\end{array}$ & $\begin{array}{l}8.398 E-01 \\
1.401 E-05\end{array}$ \\
\hline EU-154 & $3.312 E+00$ & $2.153 E-02$ & $3.333 E+00$ & 8. 353E-03 & $5.429 \mathrm{E}-01$ & $5.513 E-01$ \\
\hline (CI) I & & & & & & \\
\hline $\begin{array}{l}Y 1-54 \\
Y-80\end{array}$ & $\begin{array}{l}3.3312+00 \\
3.306 E+00\end{array}$ & $\begin{array}{l}2.165 \mathrm{E}-03 \\
1.853 \mathrm{E}-02\end{array}$ & $\begin{array}{l}3.3332+00 \\
3.3225+00\end{array}$ & $\begin{array}{l}8.373 E-03 \\
6.015 E-03\end{array}$ & & \\
\hline $\begin{array}{l}R B-108 \\
I-132\end{array}$ & $\begin{array}{l}5.018 E-03 \\
3.067 E+00\end{array}$ & $\begin{array}{l}3.011 E-06 \\
1.840 E-03\end{array}$ & $\begin{array}{l}5.021 E-03 \\
3.069 E+00\end{array}$ & $\begin{array}{l}3.712 E-00 \\
5.809 E-04\end{array}$ & $\begin{array}{l}2.227 E-08 \\
3.486 E-03\end{array}$ & $\begin{array}{l}2.596 E-08 \\
4.067 E-03\end{array}$ \\
\hline$I-133$ & $300 \mathrm{E}+00$ & $1.980 \mathrm{E}-03$ & $3.302 E+00$ & $3.525 \mathrm{E}-03$ & $2.115 E-02$ & $2.467 \mathrm{E}-02$ \\
\hline$I-134$ & $8+00$ & 1.C17E-03 & $3 E+00$ & $2.041 E-04$ & -03 & $8-03$ \\
\hline$I-135$ & $+\infty 0$ & $z-03$ & $8+00$ & $4 E-03$ & $5 E-03$ & $E-02$ \\
\hline CS-134 & $.300 z+00$ & $3.300 \mathrm{E}-02$ & $3.333 \mathrm{E}+00$ & $8.315 E-03$ & $:-01$ & 8.388E-01 \\
\hline $\begin{array}{l}B A-137 M \\
E U-154\end{array}$ & $\begin{array}{l}2.109 E-01 \\
3.312 E+00\end{array}$ & $\begin{array}{l}1.265 E-04 \\
2.253 E-02\end{array}$ & $\begin{array}{l}2.110 \mathrm{E}-01 \\
3.333 \mathrm{E}+00\end{array}$ & $\begin{array}{l}7.975 E-07 \\
8.353 E-03\end{array}$ & $\begin{array}{l}4.785 E-06 \\
5.428 E-01\end{array}$ & $\begin{array}{l}5.582 E-06 \\
5.513 \varepsilon-01\end{array}$ \\
\hline (CI) & & & & & & \\
\hline$m-54$ & $18+00$ & 2.1 & $3.3332+00$ & $8.373 E-03$ & $5.442 E-02$ & $9 E-02$ \\
\hline $\begin{array}{l}Y-90 \\
R H-10\end{array}$ & $\begin{array}{l}2 E+00 \\
3 E-04\end{array}$ & & $\begin{array}{l}E+00 \\
E-04\end{array}$ & $\begin{array}{l}09 E-03 \\
5 S E-10\end{array}$ & & $\begin{array}{l}E-01 \\
E-09\end{array}$ \\
\hline$I-132$ & $4 E+00$ & 1.7 & $2.885 E+00$ & $5.6518-04$ & -03 & $3.956 \mathrm{E}-03$ \\
\hline$I-1$ & $8+\infty$ & 1.874 & $\$+0$ & .03 & E-02 & -02 \\
\hline & & 1.5 & & & $1612-03$ & \\
\hline & $\mathbf{E}+00$ & & $+\infty 0$ & $E-03$ & & -02 \\
\hline $\begin{array}{l}C s-134 \\
B A-137 M\end{array}$ & $\begin{array}{l}3.300 E+00 \\
8.406 E-02\end{array}$ & $\begin{array}{l}3.300 E-02 \\
5.044 E-05\end{array}$ & $\begin{array}{l}3.333 \mathrm{E}+00 \\
8.411 \mathrm{E}-02\end{array}$ & $\begin{array}{l}8.315 E-03 \\
3.178 E-07\end{array}$ & $\begin{array}{l}6.315 \mathrm{E}-01 \\
1.807 \mathrm{E}-06\end{array}$ & $\begin{array}{l}\text { 8. 398E-01 } \\
2.225 E-06\end{array}$ \\
\hline & $E+\infty 00$ & $2.153 \mathrm{E}-02$ & $3.333 E+00$ & 8. $353 \mathrm{E}-03$ & $5.428 \mathrm{E}-01$ & 5.513E-01 \\
\hline (CI) $\quad I R=$ & 5 & & & & & \\
\hline $\begin{array}{l}M 1-54 \\
Y-90\end{array}$ & & $\begin{array}{l}2.165 E-03 \\
1.640 E-02\end{array}$ & $\begin{array}{l}3.333 E+00 \\
3.315 E+00\end{array}$ & $\begin{array}{l}8.372 E-03 \\
6.002 E-03\end{array}$ & $\begin{array}{l}\text { L2E-02 } \\
01 E-01\end{array}$ & $\begin{array}{l}6.279 \\
3.0611\end{array}$ \\
\hline $\begin{array}{l}8 B-106 \\
I-132\end{array}$ & $\begin{array}{l}6.595 \mathrm{E}-05 \\
2.003 \mathrm{~B}+00\end{array}$ & $\begin{array}{l}3.957 E-08 \\
1.742 E-03\end{array}$ & $\begin{array}{l}6.599 E-05 \\
2.804 E+00\end{array}$ & $\begin{array}{l}4.878 z-11 \\
5.498 z-04\end{array}$ & $\begin{array}{l}2.927 E-10 \\
3.299 E-03\end{array}$ & $\begin{array}{l}3.414 E-10 \\
3.848 E-03\end{array}$ \\
\hline$I-133$ & +00 & 1.068 & & $3.503 E-03$ & $2.102 E-02$ & $2.452 E-02$ \\
\hline & & & $2.341 E+00$ & $1.7728-04$ & $1.063 \mathrm{E}-03$ & $1.240 E-03$ \\
\hline
\end{tabular}




$\begin{array}{llllllll}I-135 & 3.174 E+00 & 1.904 E-03 & 3.176 E+00 & 1.514 E-03 & 9.087 E-03 & 1.060 E-02 \\ \text { CS-134 } & 3.300 E+00 & 3.300 E-02 & 3.333 E+00 & 8.315 E-03 & 8.315 E-01 & 8.398 E-01 \\ \text { BA-137M } & 3.350 E-02 & 2.010 E-05 & 3.352 E-02 & 1.267 E-07 & 7.601 E-07 & 8.867 E-07 \\ \text { EU-154 } & 3.312 E+00 & 2.153 E-02 & 3.333 E+00 & 8.353 E-03 & 5.428 E-02 & 5.513 E-01\end{array}$

$\begin{array}{cccccc}\text { RATES } & \text { DEP ON WATER } & \text { VOLAT WATER } & \text { SURF RUNOFF } & \text { GRWIR RUNOFF } & \text { WASELOAD } \\ \text { (CI/MOA) } & & & & & \\ \text { IN-54 } & 0.000 E-01 & 0.000 E-01 & 0.000 E-01 & 0.000 E-01 & 0.000 E-01 \\ \text { Y-00 } & 0.000 E-01 & 0.000 E-01 & 0.000 E-01 & 0.000 E-01 & 0.000 E-01 \\ \text { RB-106 } & 0.000 E-01 & 0.000 E-01 & 0.000 E-01 & 0.000 E-01 & 0.000 E-01 \\ I-132 & 0.000 E-01 & 0.000 E-01 & 0.000 E-01 & 0.000 E-01 & 0.000 E-01 \\ I-133 & 0.000 E-01 & 0.000 E-01 & 0.000 E-01 & 0.000 E-01 & 0.000 E-01 \\ I-134 & 0.000 E-01 & 0.000 E-01 & 0.000 E-01 & 0.000 E-01 & 0.000 E-01 \\ I-135 & 0.000 E-01 & 0.000 E-01 & 0.000 E-01 & 0.000 E-01 & 0.000 E-01 \\ \text { CS-134 } & 0.000 E-01 & 0.000 E-01 & 0.000 E-01 & 0.000 E-01 & 0.000 E-01 \\ \text { BA-137M } & 0.000 E-01 & 0.000 E-01 & 0.000 E-01 & 0.000 E-01 & 0.000 E-01 \\ \text { EU-154 } & 0.000 E-01 & 0.000 E-01 & 0.000 E-01 & 0.000 E-01 & 0.000 E-01\end{array}$

\begin{tabular}{|c|c|c|c|c|c|c|}
\hline & & IDR COAPARI & $\tan$ & SEDI & MENT CONPAR & IrEAT \\
\hline SIIVITY & DISSOLV D & ADSCRBED & TOTAL & DISSOLVIXD & ADSORBED & TOTAL \\
\hline (CI) IR= & 1 & & & & & \\
\hline & $3.331 E+00$ & $2.165 E-03$ & $3.333 E+00$ & $8.3732-03$ & $5.442 E-02$ & $6.280 \mathrm{E}-02$ \\
\hline $\mathbf{Y}-\mathbf{8 0}$ & $3.313 E+00$ & $1.657 \mathrm{E}-02$ & $3.330 \mathrm{E}+00$ & $6.029 \mathrm{E}-03$ & $3.014 E-01$ & $3.075 E-01$ \\
\hline$R B-106$ & $3.819 \mathrm{E}-01$ & $2.291 E-04$ & $3.821 E-01$ & $2.8255-07$ & $1.695 \mathrm{E}-06$ & $1.877 \mathrm{E}-06$ \\
\hline $\begin{array}{l}I-13: \\
I-133\end{array}$ & $\begin{array}{l}3.241 E+00 \\
3.321 E+00\end{array}$ & $\begin{array}{l}1.944 E-03 \\
1.993 E-03\end{array}$ & $\begin{array}{l}3.243 E+00 \\
3.323 E+00\end{array}$ & $\begin{array}{l}6.138 E-04 \\
3.547 E-03\end{array}$ & $\begin{array}{l}3.683 E-03 \\
2.128 E-02\end{array}$ & $\begin{array}{l}4.297 E-03 \\
2.483 E-02\end{array}$ \\
\hline $\begin{array}{l}I-134 \\
I-135\end{array}$ & $\begin{array}{l}3.104 E+00 \\
3.298 E+00\end{array}$ & $\begin{array}{l}1.862 E-03 \\
1.980 E-03\end{array}$ & $\begin{array}{l}3.106 E+00 \\
3.301 E+00\end{array}$ & $\begin{array}{l}2.350 E-04 \\
1.574 E-03\end{array}$ & $\begin{array}{l}1.410 E-03 \\
9.446 E-03\end{array}$ & $\begin{array}{l}1.645 E-03 \\
1.102 E-02\end{array}$ \\
\hline CS-134 & $3.300 \mathrm{E}+00$ & $3.300 E-02$ & $3.333 E+00$ & 8. 315E-03 & $8.315 \mathrm{E}-01$ & $8.398 \mathrm{E}-01$ \\
\hline $\mathrm{BA}-237 \mathrm{M}$ & $28 E+00$ & $6 E-04$ & $1.329 E+00$ & $.020 B-06$ & $3.012 E-05$ & $3.514 E-05$ \\
\hline EU-154 & $E+00$ & $2.153 \mathrm{E}-02$ & $3.333 E+00$ & 8. $353 E-03$ & $5.429 E-01$ & $5.513 E-01$ \\
\hline (CI) $\quad \mathrm{IR}=$ & 2 & & & & & \\
\hline $\begin{array}{l}M A-54 \\
Y-80\end{array}$ & $\begin{array}{l}3.331 E+00 \\
3.310 z+00\end{array}$ & $\begin{array}{l}2.165 E-03 \\
1.655 E-02\end{array}$ & $\begin{array}{l}3.333 E+00 \\
3.326 E+00\end{array}$ & $\begin{array}{l}8.373 E-03 \\
6.022 E-03\end{array}$ & $\begin{array}{l}5.442 E-02 \\
3.011 E-01\end{array}$ & $\begin{array}{l}6.280 E-02 \\
3.071 E-01\end{array}$ \\
\hline $\begin{array}{l}R B-106 \\
I-132\end{array}$ & $\begin{array}{l}4.378 E-02 \\
3.153 E+00\end{array}$ & $\begin{array}{l}2.627 E-05 \\
1.892 E-03\end{array}$ & $\begin{array}{l}4.380 E-02 \\
3.155 E+00\end{array}$ & $\begin{array}{l}3.238 E-08 \\
5.972 E-04\end{array}$ & $\begin{array}{l}1.943 E-07 \\
3.583 E-03\end{array}$ & $\begin{array}{l}2.267 E-07 \\
4.180 E-03\end{array}$ \\
\hline$I-133$ & $3.311 E+00$ & $1.986 \mathrm{E}-03$ & $13 E+00$ & $3.536 E-03$ & $1 E-02$ & $2.475 E-02$ \\
\hline$I-134$ & $E+00$ & $1.7358-03$ & $2.894 \mathrm{E}+00$ & $2.190 \mathrm{E}-04$ & $1.314 \mathrm{E}-03$ & 1. $5335-03$ \\
\hline$I-135$ & $3.267 E+00$ & $1.960 \mathrm{E}-03$ & $392 x+00$ & $1.559 \mathrm{E}-03$ & $9.355 E-03$ & $1.081 E-02$ \\
\hline $\operatorname{cs}-134$ & $3.300 E+00$ & $3.300 \mathrm{E}-02$ & & $.315 E-03$ & $15 E-01$ & 8. 398E-01 \\
\hline $\begin{array}{l}B A-137 M \\
E U-154\end{array}$ & $\begin{array}{l}5.2925-01 \\
3.312 E+00\end{array}$ & $\begin{array}{l}3.175 E-04 \\
2.153 E-02\end{array}$ & $\begin{array}{l}5.295 E-41 \\
3.333 E+00\end{array}$ & $\begin{array}{l}2.001 E-06 \\
8.353 E-03\end{array}$ & $\begin{array}{l}1.201 E-05 \\
5.429 E-01\end{array}$ & $\begin{array}{l}1.401 E-05 \\
5.513 E-01\end{array}$ \\
\hline (CI) $\mathrm{IR}=$ & 3 & & & & & \\
\hline Mid-54 & $8+00$ & E-03 & $12+00$ & $3 E-03$ & E-02 & $95-02$ \\
\hline$Y-90$ & $8+00$ & $E-02$ & $3.3225+00$ & $5 E-03$ & $3 E-01$ & $3 E-01$ \\
\hline RE-106 & $8-03$ & $3.011 E-06$ & $1 E-03$ & $12 E-09$ & $2.227 E-08$ & $38 E-08$ \\
\hline$I-132$ & $E+00$ & $1.840 \mathrm{E}-03$ & $3.069 E+00$ & $5.8092-04$ & $3.486 E-03$ & $4.067 \mathrm{E}-03$ \\
\hline$I-133$ & $E+00$ & $E-03$ & $225+00$ & $3.5252-03$ & $2.115 E-02$ & 2. $467 E-02$ \\
\hline$I-134$ & $5 E+00$ & $E-03$ & $6 E+00$ & $2.041 E-04$ & $1.224 E-03$ & $3 E-03$ \\
\hline$I-135$ & $E+00$ & $2 E-03$ & $3.238 E+00$ & $1.544 E-03$ & $9.265 E-03$ & $1 E-02$ \\
\hline $\operatorname{cs}-134$ & $E+00$ & $3.300 \mathrm{E}-02$ & $E+00$ & 8. $315 E-03$ & 8.315E-01 & $8 E-01$ \\
\hline$B A-137 M$ & $92-01$ & E-06 & $0 E-01$ & $8-07$ & $5 E-06$ & $2 E-06$ \\
\hline EU-154 & $3.3125+00$ & $2.153 E-02$ & $3.3332+00$ & $8.353 E-03$ & $5.429 E-01$ & 5. 513E-01 \\
\hline (CI) $I R=$ & 4 & & & & & \\
\hline M-54 & $3.3312+00$ & E-03 & $3 E+00$ & & 5.4 & 6.2 \\
\hline$Y-90$ & $E+00$ & $E-02$ & $E+00$ & 03 & $4 E-01$ & $E-01$ \\
\hline$R B-106$ & $53 E-04$ & $25-07$ & $5.756 E-04$ & $4.255 \mathrm{E}-10$ & EE-09 & 2. $.979 \mathrm{E}-08$ \\
\hline$I-132$ & $E+00$ & E-03 & $5 E+00$ & $1 E-04$ & $1 E-03$ & $3.956 \mathrm{E}-03$ \\
\hline$I-133$ & $E+00$ & $1.974 \mathrm{E}-03$ & $92 \mathrm{E}+00$ & $3.514 E-03$ & 2. $108 E-02$ & $O E-02$ \\
\hline$I-134$ & $5+00$ & $1.5072-03$ & $25+00$ & $1.9012-04$ & $1.141 \mathrm{E}-03$ & $1 E-03$ \\
\hline$I-135$ & $5 E+00$ & $1.9235-03$ & $7 E+00$ & $1.528 E-03$ & $9.175 E-03$ & OE-02 \\
\hline CS-134 & $3.300 \mathrm{E}+00$ & 3.300E-02 & 3. $333 E+00$ & & $15 E-01$ & $885-01$ \\
\hline$B A-137 A$ & 8. $406 E-02$ & $5.044 E-05$ & $8.411 E-02$ & $3.178 \mathrm{E}-07$ & $1.807 E-06$ & $2.225 E-06$ \\
\hline & & $2.153 \mathrm{E}-02$ & & $8.353 E-03$ & $5.428 \Sigma-01$ & $5.513 E-01$ \\
\hline (CI) $\quad I R=$ & 5 & & & & & \\
\hline & & & $E+00$ & & 02 & .278 \\
\hline
\end{tabular}




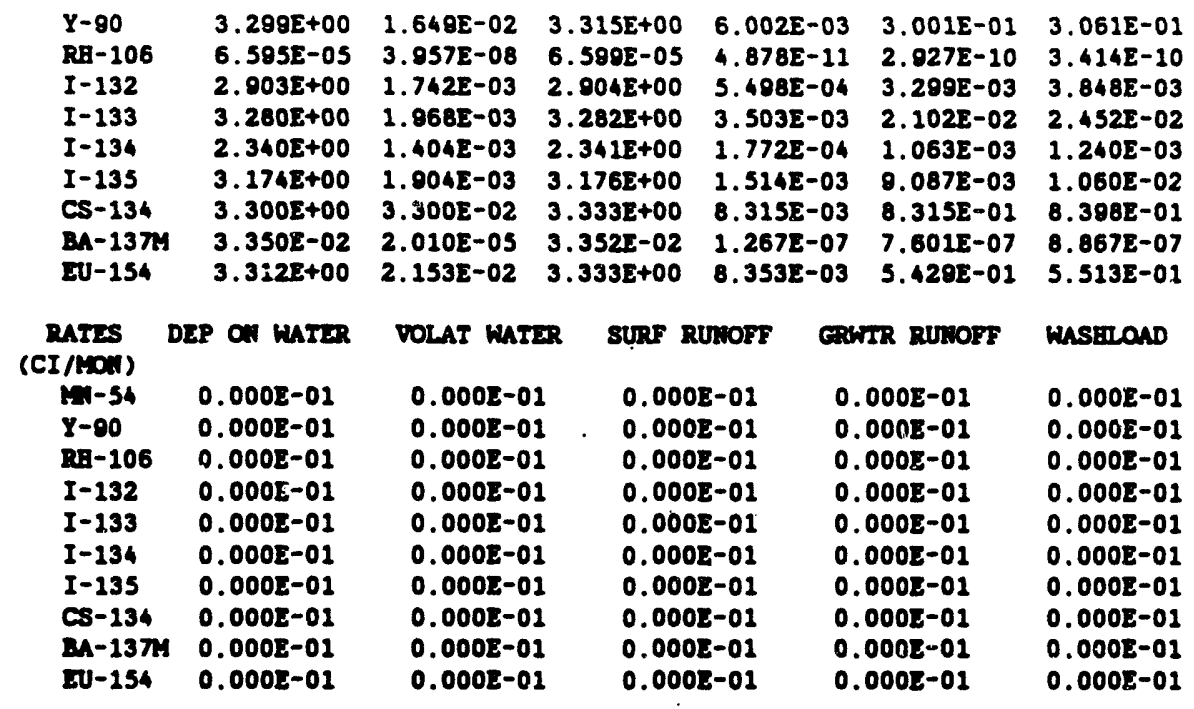




\section{APPENDIX E \\ MODEL RESULTS COMPARED WITH ANALYTICAL CALCULATIONS}

RIVER-RAD results from the first reach of a river can be compared with the following equation for ingrowth of activity of a radioactive daughter (J. E. Turner, 1986). ${ }^{1}$ The code was temporarily modified to prevent settling of radionuclides adsorbed to the sediment to go to the sediment compartment. This approximation cannot be compared with model results from downstream reaches below the first reach since these reaches receive daughters.

$$
\frac{A_{d}}{A_{p}}=\frac{\lambda_{d}\left(e^{-\lambda_{t}}-e^{-\lambda_{d}}\right)}{\lambda_{d}-\lambda_{p}} \text {. }
$$

where $A_{d}$ is the activity of the daughter, $A_{p}$ is the activity of the parent, $\lambda_{p}$ and $\lambda_{d}$ are the decay constants for the parent and daughter, respectively. The following table shows results for several chains. The residence time is the length of the reach divided by the water velocity, both of which were used in the model simulations.

Table E.1. RIVER-RAD Results Compared to Analytical Calculations from Eq. (1)

\begin{tabular}{|cccc|}
\hline Parent/Daughter & $\begin{array}{c}\text { Residence Time } \\
(s)\end{array}$ & $\begin{array}{c}\text { Eq. (1) } \\
A_{d} / A_{p}\end{array}$ & $\begin{array}{c}\text { RIVER-RAD } \\
A_{d} / A_{p}\end{array}$ \\
\hline $\mathrm{Sr}-90 / \mathrm{Y}-90$ & 333.33 & $1.0 \mathrm{E}-3$ & $1.0 \mathrm{E}-3$ \\
$\mathrm{Sr}-90 / \mathrm{Y}-90$ & 3333.3 & $9.963 \mathrm{E}-3$ & $9.916 \mathrm{E}-3$ \\
$\mathrm{Sr}-90 / \mathrm{Y}-90$ & 5000.0 & $1.491 \mathrm{E}-2$ & $1.480 \mathrm{E}-2$ \\
$\mathrm{Sr}-90 / \mathrm{Y}-90$ & 33333.3 & $9.528 \mathrm{E}-2$ & $9.100 \mathrm{E}-2$ \\
$\mathrm{Ra}-225 / \mathrm{Ac}-225$ & 333.33 & $2.674 \mathrm{E}-4$ & $2.674 \mathrm{E}-4$ \\
$\mathrm{Th}-228 / \mathrm{Ra}-224$ & 333.33 & $7.384 \mathrm{E}-4$ & $7.380 \mathrm{E}-4$ \\
$\mathrm{Ra}-228 / \mathrm{Ac}-228$ & 333.33 & $1.042 \mathrm{E}-6$ & $1.036 \mathrm{E}-2$ \\
$\mathrm{Th}-232 / \mathrm{Ra}-228$ & 333.33 & $1.273 \mathrm{E}-6$ & $1.273 \mathrm{E}-6$ \\
$\mathrm{Ru}-106 / \mathrm{Rh}-106$ & 333.33 & $9.996 \mathrm{E}-1$ & $8.850 \mathrm{E}-1$ \\
$\mathrm{Am}-241 / \mathrm{Np}-237$ & 333.33 & $0.000 \mathrm{E}+0$ & $-3.42 \mathrm{E}-12$ \\
$\mathrm{~Np}-237 / \mathrm{Pa}-233$ & 333.33 & $9.902 \mathrm{E}-5$ & $9.904 \mathrm{E}-5$ \\
$\mathrm{Tc}-99 \mathrm{~m} / \mathrm{Tc}-99$ & 333.33 & $3.42 \mathrm{E}-11$ & $3.44 \mathrm{E}-11$ \\
\hline
\end{tabular}

It is clear from the table that the longer the residence time, the greater the difference in the results from RIVER-RAD and Eq. (1). Rh-106 is a short-lived daughter of Ru-106 and results of the model are not as accurate in these cases. However, results for short-lived daughters can be set equal to the parent in RIVER-RAD (see Sect. 4.2 and Table 2, card 3).

\footnotetext{
(1986).

'Turner, J. E., Atoms, Radiation, and Radiation Protection. Pergamon Press, Inc.
} 


\section{INTERNAL DISTRIBUTION}
1. A. L. Brenkert
2. C. C. Coutant
3. D. E. Fields
4. T. A. Fontaine
5. R. H. Fowler
6-10. D. M. Hetrick
11. J. T. Holdeman
12. J. A. Holmes
13. D. D. Huff
14. R. H. Ketelle
15. D. W. Lee
16. C. A. Little
17. R. J. Luxmoore
18-22. L. M. McDowell-Boyer
23. F. R. O Donnell
24. R. V. O Neill

25-29. M. R. Patterson

30-32. C. H. Shappert

33. R. D. Sharp

34-38. A. L. Sjoreen

39-43. D. J. Thorne

44. C. C. Travis

45. R. I. Van Hook

46. R. C. Ward

47. G. E. Whitesides

48. M. W. Yambert

49. Central Research $T$ ibrary

50. ORNL Y-12 Research Library Document Reference Section

51. Laboratory Records Department

52. Laboratory Records, ORNL (RC)

53. ORNL Patent Office

\section{EXTERNAL DISTRIBUTION}

54. G. L. Baughman, U.S. Environmental Protection Agency, Environmental Research Laboratory, Athens, GA 30613

55. R. S. Kinerson, U.S. Environmental Protection Agency, 401 M Street, SW, Washington, D.C. 20460

56. L. A. Mulkey, U.S. Environmental Protection Agency, Environmental Research Laboratory, Athens, GA 30613

57. J. N. Rogers, Division 8324, Sandia Laboratories, Livermore, CA 94550

58. Office of the Assistant Manager for Energy Research and Development, U.S. Department of Energy Field Office, Oak Ridge (DOE-OR), P.O. Box 2001, Oak Ridge, TN 37831

59-68. Office of Scientific and Technical Information, P.O. Box 62, Oak Ridge, TN 37831 

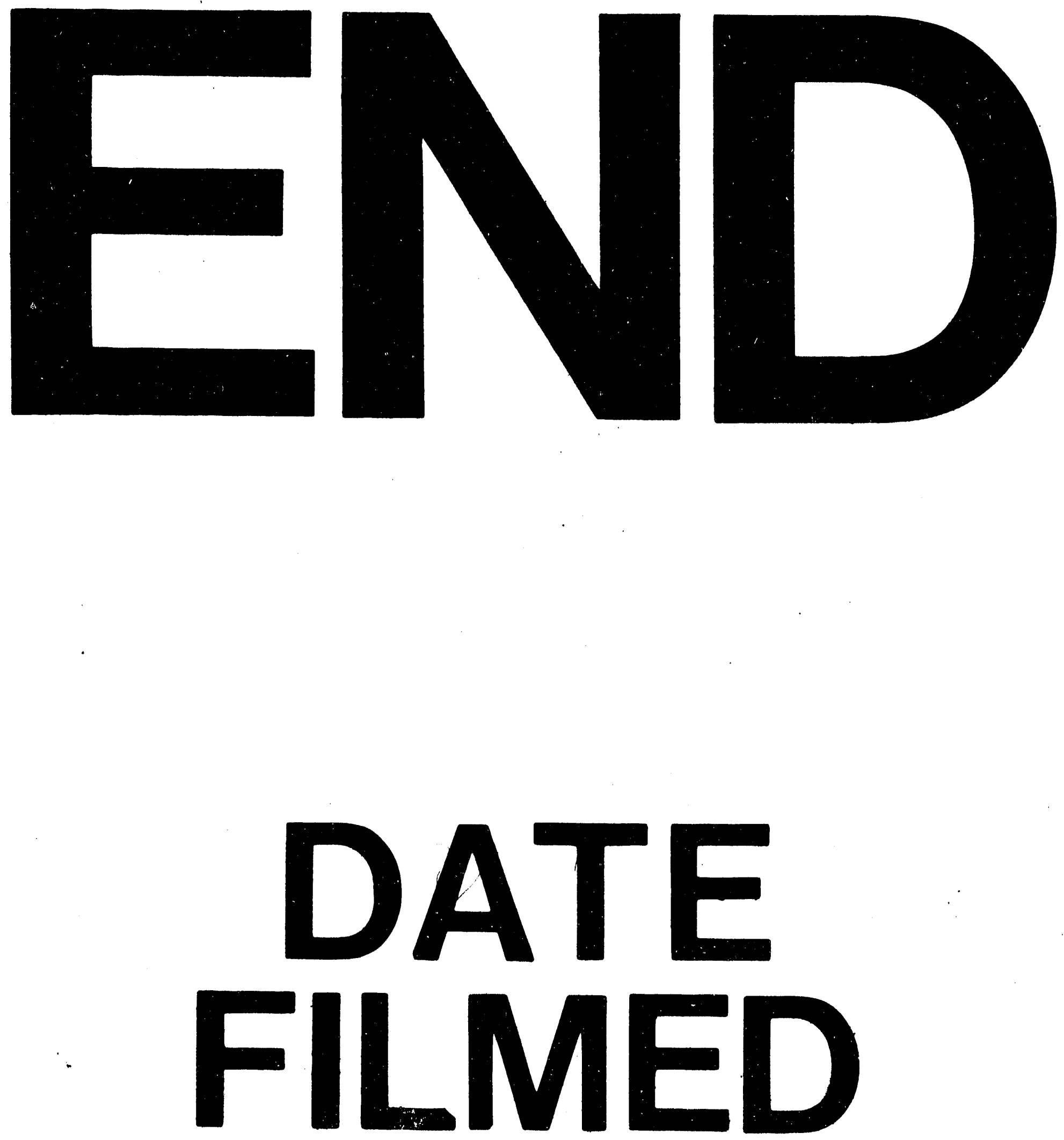

1

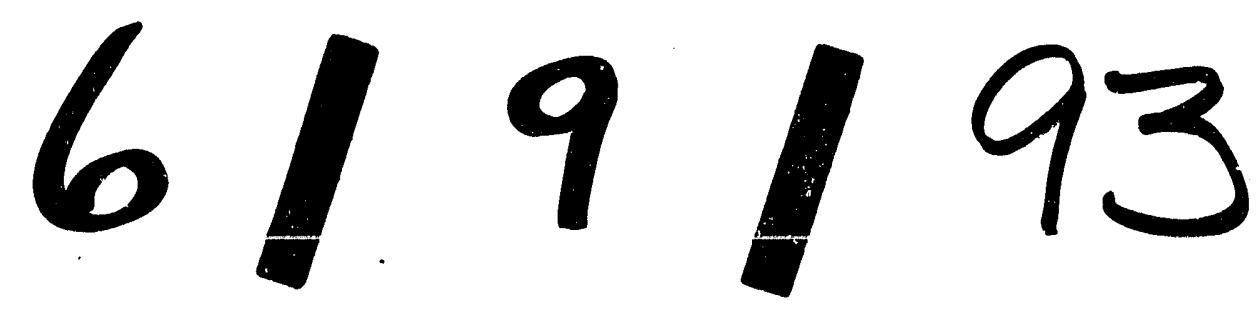


